\title{
RESUMOS DE DISSERTAÇÕES DE MESTRADO E TESES DE DOUTORADO APRE- SENTADAS NA FACULDADE DE MEDICINA DE RIBEIRÃO PRETO - USP DE ABRIL A JUNHO DE 2006
}

\section{CLÍNICA CIRÚRGICA}

\section{ESTUDO DO ÍNDICE DE ABSORÇÃO DE ENXERTO DE GORDURA AUTÓLOGA EM CÃES COM PREGA VOCAL PARALIZADA}

\section{Leonardo de Souza Kruschewsky}

Orientador: Prof.Dr. Francisco V. de Mello Filho

Tese de Doutorado apresentada em 05/04/06

O uso de enxerto de gordura é objeto de estudo em várias áreas da medicina, incluindo a laringologia. Questionamentos sobre o uso de enxerto de gordura autólogo em prega vocal existem como, se é o enxerto de gordura autólogo um elemento útil no tratamento da paralisia de prega vocal unilateral em seres humanos? E a constatação de diferentes graus de absorção do enxerto de gordura usado em varias áreas da medicina? Estas são algumas das perguntas que motivaram o desenvolvimento deste trabalho no âmbito da laringologia.

Objetivos: 1) Determinar o índice de absorção de enxerto de gordura autóloga, introduzido no espaço paraglótico de prega vocal esquerda paralisada de laringe de vinte e quatro cães, através de três métodos diferentes, decorridas doze semanas da enxertia; 2) Avaliação histológica de cada uma das vinte e quatro laringes enxertadas, após doze semanas.

Metodologia: $\mathrm{O}$ delineamento metodológico seguiu cinco etapas: 1) levantamento bibliográfico; 2) desenho, seleção e definição da amostra, com dois grupos, o grupo-controle, 16 animais com enxertia sem tempo de absorção, e o grupo estudo, 24 animais enxertados e observados em condições controladas, por 12 semanas; 3) discussão multicêntrica do estudo, com a colaboração da equipe do Professor Clark Rosen do UPMC, Pittsburgh, EUA; 4) metodologia cirúrgica e de estudo do enxerto, onde todos os cães foram submetidos a secção de nervo vago e recorrente esquerdos, observados por quatro semanas para confirmação da paralisia, enxertados com $2 \mathrm{ml}$ de gordura au- tóloga no espaço paraglótico, por diferentes técnicas, sendo os 16 animais do grupo-controle eutanasiados imediatamente à enxertia, e os 24 animais do grupo estudo observados por 12 semanas, eutanasiados, removidas suas laringes e estudadas por ressonância magnética com as imagens do enxerto de gordura mensuradas através de programa de computador, e cortadas para confecção de lâminas histológicas; 5) delineamento estatístico do estudo científico, estabelecendo-se $\mathrm{p}<0,05$ significativo.

Resultados: Índices Absolutos: Grupo-controle 01, volume médio de 1938,8ml, grupo-controle 02, volume médio de 1047,6ml, grupo-estudo A, volume médio de 192,38ml, grupo-estudo B, volume médio de $336 \mathrm{ml}$, grupo-estudo C, volume médio de $565 \mathrm{ml}$. Avaliação estatística: comportamento estatístico igual entre os grupos-controle, desigual entre os grupos-estudo e seus controles correspondentes e, tendência de comportamento desigual entre os grupos estudo enxertados com técnica endoscópica em favor de menor absorção para o grupo B. Achados histológicos: achados dos grupos-estudo - Grupo A detecção de enxerto em $50 \%$ e sinais de absorção em 7 dos 8 cães, Grupo B detecção de enxerto em 3 de 8 e sinais de absorção em $100 \%$, grupo $\mathrm{C}$ detecção de enxerto em 7 de 8 e sinais de absorção em 100\%, não havendo comportamento estatístico diferente entre os grupos quando comparados.

Conclusão: 1) O índice de absorção de enxerto de gordura autóloga de 24 cães foi de $82 \%$ no grupo-estudo $\mathrm{A}, 68 \%$ no grupo-estudo $\mathrm{B}, 71 \%$ no grupo-estudo C; 2) Os achados histopatológicos são semelhantes nos diferentes grupos-estudo, sem diferença estatística e sinalizam absorção de gordura enxertada. 


\section{EFEITO DA RADIOTERAPIA PÉLVICA PRÉ-OPERATÓRIA NA CICATRIZAÇÃO DE ANASTOMOSES COLÔNICAS. ESTUDO EXPERIMENTAL EM RATOS}

Alexandre Franca Almeida

Orientador: Prof. Dr. Omar Féres

Dissertação de Mestrado apresentada em 28/04/2006

As deiscências das anastomoses colorretais estão associadas com elevada taxas de morbidade e mortalidade pós-operatória. A deiscência é a consequiência da falha na cicatrização de uma anastomose. Muitos fatores estão associados com uma deficiente cicatrização e com o aumento da incidência de deiscências anastomóticas: fatores técnicos, fatores sistêmicos e fatores locais, como a radioterapia pré-operatória. Esta técnica de radioterapia vem sendo utilizada com grande frequiência no tratamento dos tumores de reto. Apresenta muitas vantagens como redução da recidiva pélvica, aumento do tempo livre de doença e aumento da sobrevida global, além da chance de uma cirurgia com preservação esficteriana devido ao rebaixamento do estadiamento que pode causar nos tumores de reto. Entretanto, muitas dúvidas existem quanto à segurança da confecção de uma anastomose colorretal na pelve irradiada, assim como qual seria o melhor momento para realizar a cirurgia após o final da radioterapia. Desta forma, foi desenvolvido este estudo experimental, com o objetivo de avaliar a cicatrização da anastomose após a radioterapia e estabelecer o intervalo mais adequado entre o fim da radioterapia e o tratamento cirúrgico com uma anastomose colorretal. Os animais utilizados foram os ratos, distribuídos em 3 grupos: um grupo controle submetido somente à confecção da anastomose, um grupo operado após 4 semanas do final da radioterapia pré-operatória e um grupo operado após 8 semanas. A radioterapia foi realizada com uma dose total de $4500 \mathrm{cGy}$, fracionada em 5 semanas, 180cGy/dia. Após 7 dias da realização da anastomose, os animais foram sacrificados sendo feita no mesmo ato a avaliação macroscópica da cavidade abdominal e retirada do segmento contendo a anastomose no centro para avaliação histopatológica, dosagem de hidroxiprolina e imuno-histoquímica para metaloproteinase 1, inibidor da metaloproteinase $1 \mathrm{e}$ VGEF - fator de crescimento endotelia vascular. A avaliação macroscópica demonstrou que todos os grupos apresentaram formação de aderência intraperitoneais, mas somente os grupos submetidos à radioterapia apresentaram deiscência e abscessos perianastomótico, embora sem significância estatística. A avaliação histopatológica demonstrou significado estatístico para os seguintes parâmetros: edema, congestão vascular, crosta fibrino-leucocitária, exsudato eosinofílilco, infiltrado macrofágico e hemorragia focal. A dosagem de hidroxiprolina demonstrou uma maior volume no grupo operado após 8 semanas de forma estatisticamente significativa. Quanto à imuno-histoquímica, o grupo operado após 8 semanas apresentava maior concentração de metaloproteinase, com p > 0,05; não houve diferença entre os grupos quando comparados para a quantidade de inibidor da metaloproteinase 1 e VGEF. A comparação dos nossos resultados com a literatura demonstra tanto estudos com desfechos semelhantes, quanto resultados divergentes e controversos. Devido a uma grande variedade de metodologias empregadas tanto no esquema de aplicação da radioterapia préoperatória, quanto na avaliação da anastomose, diversos resultados são obtidos a partir dos estudos clínicos e experimentais, tornando a comparação dos resultados entres o trabalhos científicos menos rigorosa. No nosso estudo, concluímos que a radioterapia não aumenta a incidência de deiscência pós-operatória; modifica a evolução normal do processo inflamação / cicatrização durante a avaliação histopatológica; uma maior dosagem de hidroxiprolina no grupo operado após 8 semanas sugere melhor momento para realização do procedimento cirúrgico, e a quantidade de metaloproteinase 1 está maior no grupo operado após 8 semanas, sugerindo uma maior lise de colágeno neste grupo.

\section{ESTUDO DA HEMODINÂMICA VENOSA POR MEIO DA PLETISMOGRAFIA A Ar NO PRÉ E PÓS-OPERATÓRIO DE VARIZES DOS MEMBROS INFERIORES}

Nei Rodrigues Alves Dezotti

Orientador: Prof.Dr.Carlos Eli Piccinato

Tese de Doutorado apresentada em 11/05/2006
A doença venosa crônica (DVC) dos membros inferiores é caracterizada por sintomas e sinais produzidos pela hipertensão venosa, resultado de altera- 
ções funcionais e estruturais da parede das veias. Abrange desde as telangiectasias às úlceras flebopáticas abertas e constitui grave problema de saúde pública. Na evolução da DVC as varizes primárias dos membros inferiores (MMII) representam uma das afecções mais atendidas em ambulatórios de Cirurgia Vascular e Angiologia. Com base nestes aspectos surgiu a idéia de estudar as alterações da hemodinâmica venosa em pacientes portadores de varizes primárias dos membros inferiores no pré e pós-operatório, utilizando a Pletismografia a Ar (PGA). Investigou-se quantitativamente o possível alívio da estase venosa e também a correlação entre a alteração hemodinâmica e a classificação CEAP utilizada como padrão de estudo da DVC. A PGA é um exame que mede, de forma não invasiva, as variações absolutas de volume sangüíneo da perna (em $\mathrm{ml}$ ), refluxo venoso pelo Índice de Enchimento Venoso - IEV (em $\mathrm{ml} / \mathrm{s}$ ) e a capacidade de ejeção da musculatura da panturrilha como resultado de um movimento de flexão plantar pela Fração de Ejeção - FE (em \%) ou exercício contínuo pela Fração de Volume Residual - FVR (em \%). Foram estudados 63 MMII em 39 pacientes (35 mulheres e 4 homens), com idade média igual a 46,3 anos, operados no Hospital das Clínicas da Faculdade de
Medicina de Ribeirão Preto da Universidade de São Paulo, no período de janeiro de 2001 a dezembro de 2004. Os membros inferiores foram classificados de acordo com a Classificação Internacional CEAP, em critério clínico $=\mathrm{C}_{2}$ a $\mathrm{C}_{6}\left(\mathrm{C}_{2}=6, \mathrm{C}_{3}=32, \mathrm{C}_{4}=15\right.$, $\mathrm{C}_{5}=7$ e $\mathrm{C}_{6}=3$ ), critério etiológico $=\mathrm{Ep}$, critério anatômico $=$ As e critério fisiopatológico $=$ Pr. Os pacientes foram avaliados por exame clínico pré e pós-operatório, Mapeamento Dúplex pré-operatório e PGA pré e pós-operatória. Os 63 MMII foram subdivididos em três grupos adotando-se o critério lesão de pele como referência, sendo: grupo $\mathrm{C}_{2}+\mathrm{C}_{3}$; grupo $\mathrm{C}_{4} \mathrm{e}$ grupo $\mathrm{C}_{5}+\mathrm{C}_{6}$. Houve melhora significativa da hemodinâmica venosa no pós-operatório demonstrado pela diminuição significativa do IEV e da FVR e aumento da FE nos MMII submetidos à cirurgia de varizes. O tratamento cirúrgico beneficiou os três grupos, mas a melhora mais acentuada foi observada no grupo de gravidade clínica maior (grupo $\mathrm{C}_{5}+\mathrm{C}_{6}$ ). $\mathrm{O}$ melhor parâmetro obtido pela PGA para correlação com a classificação CEAP foi o IEV. Assim, a cirurgia de exérese de varizes superficiais contribuiu para aliviar a estase venosa de membros inferiores com base no estudo da hemodinâmica venosa por meio da PGA no pré e pós-operatório.

\section{O EFEITO DA CLORPROMAZINA NA FUNÇÃO RENAL, MITOCONDRIAL E PEROXIDAÇÃO LIPÍDICA NA ISQUEMIA E REPERFUSÃO RENAL}

\section{Roberto Marins de Carvalho}

Orientador: Prof.Dr. Silvio Tucci Jr.

Tese de Doutorado apresentada em 12/05/2006

Objetivos: Avaliar a influência da administração intravenosa de clorpromazina (CPZ) na função renal, mitocondrial e peroxidação lipídica do rim em modelo experimental de isquemia renal normotérmica em ratos, seguida de reperfusão sanguínea.

Métodos: 79 ratos Wistar foram submetidos à isquemia renal esquerda durante 60 minutos, seguida de reperfusão do órgão e nefrectomia contra-lateral. 42 ratos receberam CPZ (3mg/kg I.V.) 15 minutos antes da indução da isquemia. Foram realizadas dosagens de uréia e creatinina, determinações da função mitocondrial (estados III e IV, Razão de Controle Respiratório-RCR, Potencial de Membrana-PM e Intumescimento Osmótico Mitocondrial-IOM) e avaliação da peroxidação lipídica pela dosagem de Malondialdeído (MDA). Estes ensaios foram realizados 24 horas, 4 e 7 dias pós reperfusão renal.

Os dados foram analisados pelos testes de Friedman e Mann-Whitney. Para as variáveis PM e IOM utilizou-se o teste de Tukey e para o malondialdeído usou-se o teste de Kruskall-Wallis.

Resultados: Nos ratos que não receberam CPZ observou-se elevação dos níveis de uréia $(p<0,001)$ e creatinina $(p<0,001)$ em relação aos valores pré-isquemia após a reperfusão renal. O mesmo foi observado em relação à respiração mitocondrial no estado III $(\mathrm{p}<0,001)$ e para os resultados com PM $(\mathrm{p}<0,01)$. Em relação ao estado IV, IOM e MDA, não houve diferenças estatísticamente significantes entre os grupos.

Conclusões: A clorpromazina teve um efeito protetor sobre a função renal e mitocondrial como demonstrado pelo estado III e PM. 


\section{ESTUDO DAS ALTERAÇÕES CAUSADAS, PELA HIDROCEFALIA INDUZIDA POR CAULIM, NO CORPO CALOSO DE CÃES ADULTOS}

\section{Edvaldo José Rodrigues Cardoso}

Orientador: Prof.Dr Benedicto Oscar Colli

Tese de Doutorado apresentada em 19/05/2006

Hidrocefalia é caracterizada pela obstrução do fluxo do líquido céfalo raquidiano e aumento dos ventrículos cerebrais, e causa grande número de problemas neurológicos e neurocirúrgicos. Não há consenso na literatura sobre o animal ideal para estudo experimental desta entidade. Este trabalho teve como objetivos:

1) Verificar a eficácia da produção de hidrocefalia induzida por caulim quando injetado diretamente na cisterna magna de cães;

2) analisar a evolução da dilatação ventricular ao longo do tempo através de imagem por ressonância magnética;

3) verificar se há correlação entre a dilatação ventricular e as alterações histológicas gliais e da mielinização do corpo caloso utilizando a coloração de tricromo de Masson após um e dois meses da indução da hidrocefalia;

4) verificar se há correlação entre a dilatação ventricular e da mielinização do corpo caloso analisada pela luminescência através da coloração por solocromo-cianina, após um e dois meses da indução da hidrocefalia.

Os cães foram divididos em 3 grupos:

grupo 1 - controle sem indução de hidrocefalia; grupo 2- com indução da hidrocefalia até a quarta semana; e

grupo 3- com indução da hidrocefalia até a oitava semana.

Os parâmetros estudados foram: razão ventricular, celularidade e mielinização do corpo caloso. O estudo para cálculo do volume e da razão ventricular foi feito através de Imagem por Ressonância Magnética nas semanas zero (grupos 1,2,3), quatro (grupos 1,2,3), e oito (grupos 1 e 3); da celularidade por densidade celular por campo no microscópio e para quantificação do grau de mielinização do corpo caloso através de luminescência em cada grupo. A análise estatística foi efetuada usando os testes não paramétricos de Mann-Whitney-U e de Kruskall-Wallis (análise de variância - ANOVA) com pós-teste de múltiplas com- parações de Dunn para comparação de variáveis detectadas em momentos diferentes em um mesmo grupo ou variáveis entre diferentes grupos. A ocorrência de hidrocefalia verificada radiologicamente foi de $93,75 \%$ e a mortalidade global dos animais ao longo do experimento foi de $38,4 \%$. Os volumes e razões ventriculares obtidos por Imagem por Ressonância Magnética na semana zero foram semelhantes nos 3 grupos estudados. Os volumes e razões ventriculares foram maiores nos grupos 2 e 3 em relação ao grupo 1 após quatro e oito semanas da indução da hidrocefalia e foram semelhantes quando medidas na quarta e na oitava semanas nos animais do grupo 3 . O número médio de células observadas no esplênio do corpo caloso foi maior nos animais do grupo 2 em relação aos do grupo $1 \mathrm{e}$ foi semelhante entre os animais dos grupos 1 e 3 e grupos 2 e 3 . Os índices de luminescência foram maiores nos animais do grupo 2 quando comparados com os animais do grupo 1 no joelho e no esplênio do corpo caloso indicando que houve perda de mielina nos animais do grupo 2 e foram semelhantes nos animais do grupos 1 e 3 e grupos 2 e 3 . A queda do índice de luminescência nos animais do grupo 3 para níveis semelhantes aos do grupo 1 mostraram que após 8 semanas da indução da hidrocefalia há uma tendência à remielinização. Nas condições experimentais descritas concluiu-se que:

1) $O$ caulim mostrou-se eficaz na indução de hidrocefalia em cães adultos;

2) a imagem por ressonância magnética mostrou-se um bom método para acompanhamento da hidrocefalia experimental em cães adultos;

3) os resultados concordantes da razão e do volume ventriculares medidos por IRM permitem inferir que, pela facilidade do método de medida da razão, esta possa ser utilizada isoladamente para o acompanhamento evolutivo da hidrocefalia experimental;

4) o corpo caloso de cães não responde de maneira homogênea à indução de hidrocefalia com caulim. Houve aumento significante no número de células gliais no esplênio do corpo caloso, que se manteve estável no joelho e no corpo do corpo caloso;

5) houve perda da mielina no joelho e no esplênio do corpo caloso até a quarta semana após a indução da hidrocefalia e uma tendência à remielinização parcial até a oitava semana. 


\section{ALTERAÇÕES HISTOLÓGICAS DO FÍGADO, DO FLUXO PORTAL E DO ÓXIDO NÍTRICO NA OBSTRUÇÃO/DESOBSTRUÇÃO BILIAR}

\section{Miguel Angel Dias}

Orientador: Prof.Dr. Reginaldo Ceneviva

Dissertação de Mestrado apresentada 22/05/2006

A obstrução do ducto biliar leva à colestase extra-hepática que favorece o desenvolvimento da colangite e de alterações histológicas do fígado. Apesar dos avanços no conhecimento dos fenômenos fisiopatológicos resultantes da colestase extra-hepática, novas investigações justificam-se para uma melhor compreensão da relação entre os fatores agravantes, envolvendo, entre eles o óxido nítrico (NO) e o fluxo portal.

Objetivo: Avaliar alterações histológicas do fígado, do fluxo portal, do óxido nítrico e da peroxidação lipídica resultantes do processo de obstrução/ desobstrução biliar.

Métodos: Trinta e nove ratos Wistar foram distribuídos aleatoriamente em 4 grupos: $\mathrm{OB}(\mathrm{n}=18)$, submetido à oclusão biliar e seguido por 20 dias, com avaliação periódica das alterações histológicas do fígado, do fluxo portal mediante utilização de Doppler e dosagem de $\mathrm{NO}$ e de malondialdeído (MDA); grupo OB/DB (n=13) submetido à oclusão biliar por 20 dias e a seguir desobstrução biliar por anastomose colédoco- duodenal, com seguimento por 5 dias e avaliação dos mesmos parâmetros do grupo OB; grupo CED $(n=4)$ submetido à operação simulada, avaliação periódica do fluxo portal e seguimento por 25 dias; grupo CHB $(\mathrm{n}=4)$ submetido à operação simulada com biópsia hepática no $25^{\circ}$ dia, e seguido por 25 dias com avaliação periódica dos mesmos parâmetros do grupo $\mathrm{OB}$, com exceção da ecografia Doppler. Nos grupos OB, OB/ $\mathrm{DB}$ e CHB foram avaliadas também a bilirrubina direta (BD) e a fosfatase alcalina (FA).

Resultados: Com a oclusão do colédoco houve aumento da BD e da FA, desenvolvimento de alterações hepáticas (redução do número de hepatócitos, aumento de fibrose, fibroblastos, ductos biliares, vasos sangüíneos e células inflamatórias) e redução do fluxo portal, concomitantes com o aumento do NO plasmático e do MDA. A desobstrução biliar resultou em redução da $\mathrm{BD}$, da FA, das alterações hepáticas, aumento do fluxo portal e redução do NO e do MDA, com tendência à normalização.

Conclusão: A obstrução biliar resultou em colestase e diminuição do fluxo portal, com aumento do NO plasmático e do malondialdeído no tecido hepático e alterações histológicas do fígado, com tendência à normalização após a desobstrução biliar

\section{ALTERAÇÕES AGUDAS NA MANOMETRIA ANORRETAL E NA TOMOGRAFIA COMPUTADORIZADA INDUZIDAS POR ESFINCTEROTOMIA ANAL PROXIMAL E DISTAL. ESTUDO EXPERIMENTAL EM PORCOS}

\section{Josimeire Batista Mehl}

Orientadora: Profa.Dra. Yvone Avalloni de Morais Villela de Andrade Vicente

Tese de Doutorado apresentada 26/06/2006

Existem controvérsias na apresentação e na divisão anatômica esfincteriana anorretal, assim como, em sua representação funcional. A avaliação da musculatura esfincteriana anorretal tem sido feita por vários métodos, dentre eles, a manometria anorretal e a tomografia computadorizada. Porém, ainda não existe um modelo experimental que permita o estudo ma- nométrico detalhado. Neste trabalho, desenvolveuse um modelo experimental, para estudo manométrico e radiográfico, além da análise das alterações no comportamento dos grupos musculares, responsáveis pelo mecanismo esfincteriano anorretal, antes e após lesões proximal e distal.

Métodos: Vinte e dois porcos, de 25 a 30 dias de idade, pesando 5 a $7 \mathrm{~kg}$, foram sorteados para compor dois grupos, submetidos a lesões em diferentes níveis da musculatura anorretal. Antes e após as lesões, foram estudados por meio de manometria anorretal (reflexo inibitório anorretal e volume vetorial) e 
tomografia computadorizada (ângulo anorretal e comprimento do canal anal).

Resultados: A lesão proximal preservou o relaxamento do esfíncter e retardou o seu fechamento (velocidade de recuperação do relaxamento de $4,35 \pm 2,10 \mathrm{~mm} / \mathrm{s}$ versus $2,70 \pm 1,32 \mathrm{~mm} / \mathrm{s}(\mathrm{p}=0,001)$ ). Reduziu a pressão máxima $(62,45 \pm 20,02 \mathrm{mmHg}$ versus $40,36 \pm 12,59 \mathrm{mmHg}(\mathrm{p}=0,004))$ e o volume vetorial $(2749 \pm 921 \mathrm{mmHg} 2 \mathrm{~cm}$ versus $1591 \pm 1379$ $\mathrm{mmHg} 2 \mathrm{~cm}(\mathrm{p}=0,005))$. Houve aumento do comprimento do canal anal anatômico $(9,60 \pm 1,35 \mathrm{~mm}$ versus $13,15 \pm 3,01 \mathrm{~mm}(\mathrm{p}=0,005))$ e da zona de alta pressão $(5,09 \pm 1,04 \mathrm{~mm}$ versus $6,36 \pm 1,50 \mathrm{~mm}(\mathrm{p}=0,005))$. Contudo, conservou a porcentagem de assimetria, o com- primento do esfíncter e o ângulo anorretal. A lesão distal não alterou o reflexo inibitório anorretal, o comprimento da zona de alta pressão, a porcentagem de assimetria, o volume vetorial e os comprimentos do canal anal e do ângulo anorretal. Entretanto, aumentou o comprimento do esfíncter $(11,82 \pm 2,82 \mathrm{~mm}$ versus $14,09 \pm 2,39 \mathrm{~mm}(\mathrm{p}=0,022))$ e reduziu a pressão máxima $(60,55 \pm 22,05 \mathrm{mmHg}$ versus $40,91 \pm 13,41$ $\mathrm{mmHg}(\mathrm{p}=0,004))$.

Conclusão: Conclui-se que as alterações observadas, decorrentes das lesões proximal e distal do esfíncter anorretal, sugerem a interferência direta do músculo elevador do ânus, na função da musculatura esfincteriana.

\section{ANÁLISE MORFOLÓGICA E MORFOMÉTRICA DA COMISSURA ANTERIOR DE RATOS WISTAR SUBMETIDOS À HIDROCEFALIA EXPERIMENTAL}

\section{Kleber Tadeu Carraro}

Orientadora: Profa. Dra. Luiza da Silva Lopes

Dissertação de Mestrado apresentada em 30/06/2006

Hidrocefalia é a entidade resultante do desbalanço entre a produção e a absorção do líquido cefaloespinhal (LCE), que se acumula no interior dos ventrículos cerebrais, levando à dilatação dos mesmos. Sua fisiopatologia é multifatorial e seu principal mecanismo de lesão inclui a compressão e o estiramento, assim como edema e isquemia. Visto que, em outras comissuras cerebrais como no corpo caloso, esta patologia provoca alterações estruturais importantes, vê-se relevância em realizar estudos mais aprofundados relacionando a hidrocefalia à comissura anterior. A comissura anterior tem como principais elementos de sua composição, fibras nervosas, astrócitos e oligodendrócitos. A troca de informações entre os hemisférios cerebrais dos mamíferos depende das fibras comissurais. O presente estudo teve como objetivos avaliar as alterações morfológicas e morfométricas da comissura anterior em ratos Wistar submetidos à hidrocefalia experimental, quando considerados: grau de dilatação ventricular e tempo de progressão da hidrocefalia. Foram utilizados ratos Wistar, com sete dias de vida, sem distinção de sexo. Os filhotes foram submetidos à indução da hidrocefalia por injeção intracisternal de $0,04 \mathrm{ml}$ de caulim a $20 \%$. Um rato de cada ninhada não foi puncionado, sendo utilizado como animal controle. Os animais foram divididos em dois grupos experimentais: grupo 1, com 14 e grupo 2, com 21 dias de evolução da hidrocefalia. O material foi fixado em uma solução de paraformaldeído $2 \%$ e glutaraldeído $1 \%$. Os encéfalos foram classificados por comparação em hidrocefalia leve, moderada, acentuada e máxima. A comissura anterior foi dissecada, sob lupa, com ampliação de 4x. Realizaram-se então os procedimentos de rotina para inclusão em resina. Foram feitos cortes transversais às fibras da comissura anterior com $0,5 \mu \mathrm{m}$ de espessura e corados com azul de toluidina $1 \%$. Os aspectos morfológicos mostraram diferença cromática entre as partes anterior e posterior na comissura anterior no animais controle assim como nos hidrocefálicos. Notou-se também, através da diferença cromática, que nos animais com idades mais avançadas, ocorre o aumento da mielinização entre os tempos estudados, e também, o aparecimento de lesões nas fibras mielínicas. A análise morfométrica dos oligodendrócitos não mostrou variação estatisticamente significante, exceto entre os grupos que desenvolveram hidrocefalia acentuada. A densidade de fibras nervosas lesadas foi diretamente proporcional ao grau e também ao tempo de desenvolvimento da hidrocefalia. 


\section{CLÍNICA MÉDICA}

\section{ANÁLISE DA EXPRESSÃO DE GENES RELACIONADOS À ADESÃO CELULAR EM LEUCEMIAS AGUDAS}

\section{Marcus Vinícius Santos dos Passos}

Orientador: Prof. Dr. Wilson Araújo da Silva Júnior

Dissertação de Mestrado apresentada em 19/04/2006

Moléculas de adesão são essenciais em vários processos biológicos como proliferação, expressão gênica, diferenciação e apoptose. Na hematopoese, estas interações são fundamentais para sustentação da auto-renovação de progenitores primitivos suportando a proliferação e diferenciação em suas linhagens específicas. As leucemias agudas caracterizamse pela migração de células imaturas para a circulação periférica acarretando alterações funcionais. Vários estudos demonstram que interações anormais entre células leucêmicas e o microambiente hematopoético são fatores determinantes na disseminação, bem como nas diversas manifestações clínico-patológicas da doença. Embora haja evidências de que os mecanismos de adesão celular tenham influência no processo de malignização, pouco é conhecido sobre as bases moleculares que as governam. O presente estudo teve como objetivo avaliar o perfil da expressão dos genes de adesão celular (CD44, CDH1, CD62L) e de matriz extracelular (FN1) em leucemias agudas (LMA/LLA) classificadas segundo o critério francoamericano-britânico (FAB). A análise foi realizada em RNA total extraído de 19 amostras provenientes de pacientes com diagnósticos de leucemia e síndrome mielodisplásica (SMD), sendo 11 amostras de LMA, 1 de SMD e 7 amostras de LLA, bem como em amostra de medula óssea normal, utilizada como controle. A metodologia proposta para o estudo da expressão gênica foi a PCR semiquantitativa, onde após síntese e diluições seriadas do cDNA, (1:2 a 1:64) foi possível identificar variações de expressão dos genes propostos nas amostras leucêmicas e de tecidos normais. Como controle gênico utilizamos o gene da ('beta'actina que mostrou amplificação em todas diluições das amostras. A expressão gênica das moléculas de adesão foi bastante heterogênea, não sendo possível distinguir variações significativas entre LMA/LLA. Por outro lado, quando comparamos LMA/LLA e medula óssea normal, verificamos uma expressão aumentada de alguns destes genes nas amostras leucêmicas. Em especial, CD44 obteve uma expressão de até seis vezes maior em LMA/LLA em relação à medula normal. Hiperexpressão de CD44 têm sido correlacionada com um mau prognóstico da doença corroborando os dados da literatura científica. Podemos concluir que a heterogeneidade da expressão destas moléculas reflete a complexidade da doença demonstrando, sobretudo, que a desregulação dos contatos é determinante na disseminação de blastos leucêmicos. Este tipo de estudo permite e contribui enormemente no entendimento molecular das leucemias agudas. Além disso, a avaliação do comportamento de genes de adesão celular pode apresentar valor clínico relevante no diagnóstico e prognóstico das leucemias agudas.

\section{DADOS ANTROPOMÉTRICOS E NUTRICIONAIS DE PACIENTES OBESOS GRAU III SUBMETIDOS À GASTROPLASTIA VERTICAL COM BANDAGEM E DERIVAÇÃO INTESTINAL EM Y DE ROUX E À DIETOTERAPIA E SUPLEMEN- TAÇÃO NUTRICIONAL}

\section{Marinella Bavaresco}

Orientador: Prof. Dr. José Eduardo Dutra de Oliveira Dissertação de Mestrado apresentada em 20/04/2006

Vários estudos vêm mostrando os riscos para o desenvolvimento de problemas nutricionais após a ci- rurgia para redução de peso. O presente estudo, teve como objetivo avaliar a ingestão alimentar nos períodos pré e pós operatório, avaliar o estado nutricional dos pacientes submetidos à cirúrgica, mostrar dados hematológicos e bioquímicos durante o tratamento, acompanhar a perda ponderal e modificações na 
composição corporal. O estudo realizado com 48 pacientes, $85,4 \%$ do sexo feminino, 23 a 63 anos de idade. O peso mediano inicial foi $159,8(190,8-131) \mathrm{kg}$, com IMC de $51,2(66-45,3) \mathrm{kg} / \mathrm{m}^{2}$, a redução de peso foi 35,6\% em doze meses de seguimento. A composição corporal teve uma redução importante da gordura corporal que no inicio do estudo era de $53 \%$ ao final do seguimento foi $32 \%$ e manutenção da massa magra, $47 \%$ e $68 \%$ no inicio e final do estudo. O valor calórico antes da cirurgia foi de $2250 \mathrm{kcal} / \mathrm{dia}$ e não ultrapassou $1000 \mathrm{kcal} /$ dia durante o primeiro ano após a cirurgia. A dieta orientada era fracionada em pequenos volumes ao longo do dia, com o valor calórico sempre muito baixo há uma necessidade de suplementação com polivitamínico e minerálicos por toda a vida. Esse cuidado com a suplementação e os retornos periódicos acompanhados por toda a equipe multidisciplinar, que caracteriza o protocolo de atendimento do serviço de Nutrologia do departamento de Clinica Médica do HCFMRP-USP, são os grandes responsáveis por manter um adequado o estado nutricional. Os valores hematológicos sofreram alterações em seu quadro com quedas nos valores individuais para hemoglobina, com $\mathrm{p}<0,01$ entre pré e 1 mês e pré e 12 meses; hematócrito, com $\mathrm{p}<0,05$ entre pré e 1 mês; albumina, porém sem diferença estatística; proteína total, sem diferença estatística ao longo do estudo; ferro com diferença estatística entre pré e 1 mês, pré e 3 meses pré e 6 meses, 1 mês e 3 meses, 3 meses e 8 meses; UIBC mostrando alterações entre pré e 1 mês e pré e 8 meses $(p<0,05)$; saturação de ferro com p $<0,05$ para pré e 8 meses e 3 meses e 8 meses, porém mesmo com queda significativa os valores medianos permaneceram na normalidade. Os dados bioquímicos referentes à glicemia mostraram uma redução significativa entre pré e 6 meses $(\mathrm{p}<0,001)$, pré e 12 meses $(p<0,001)$ e 3 meses e 6 meses $(p<$ $0,05)$, chegando ao final do seguimento com $5 \%$ dos pacientes com valores acima de $110 \mathrm{mg} / \mathrm{dl}$; o colesterol total sofreu alteração entre pré e 1 mês e pré e 3 meses, com $\mathrm{p}<0,01$; para os triglicérides essa diferença foi ainda mais significante com $40 \%$ dos pacientes com níveis acima de $150 \mathrm{mg} / \mathrm{dl}$ antes e $5 \%$ após doze meses ou seja apenas 1 pacientes, a diferença foi a partir do sexto mês comparados ao pré-cirúrgico com $\mathrm{p}<0,005$; o HDL aumentos com diferença significante entre pré e 12 meses, 1 mês e 6 meses, 1 mês e 8 meses, 1 mês e 12 meses e 3 meses e 12 meses; o LDL não apresentou diferenças significativa. A associação de comorbidades é comum nos pacientes obesos, essa somatória diminuiu com a perda de peso, ao longo do seguimento.

\section{USO DA VACINA BCG COMO AGENTE IMUNOMODULADOR NA HANSENÍASE}

\section{Erika Muller Ramalho Zenha}

Orientadora: Profa. Dra. Norma Tiraboschi Foss

Dissertação de Mestrado apresentada em 28/04/2006

Hanseníase é doença infecciosa crônica, causada pelo Mycobacterium leprae. Compromete pele e nervos periféricos e constitui relevante problema de saúde pública no Brasil, com taxas de prevalência de 1,71/10000 habitantes e de detecção de 2,76/10000 habitantes no ano de 2004. Apesar da queda na prevalência, a detecção se mantém, o que tem dificultado a eliminação da hanseníase como problema de saúde pública no país, desencadeando a procura de fatores que possam atuar como adjuvantes ao tratamento e eliminação da infecção. A administração da vacina intradérmica constituída pelo Bacilo de Calmette Guérin (BCG-id) vem sendo considerada, por longo período de tempo, para estimular a reação imunológica de comunicantes de pacientes com hanseníase. Acreditase também que a combinação da poliquimioterapia convencional com essa vacinação deva facilitar a eliminação de bacilos do paciente, reduzir o índice de recidivas após a alta terapêutica e encurtar o período para negativação das baciloscopias, provavelmente, por atividade imunomoduladora, ainda não esclarecida, que resulta no aumento da defesa imunológica do paciente. Este estudo propõe a investigação do mecanismo de ação do BCG através de ensaio clínico e laboratorial, em 19 pacientes com hanseníase, subdivididos em multibacilares (MB:11) e paucibacilares (PB:8). Avaliou-se a produção in vitro de citocinas (IL-10, IFNg, TNF\& \#945; e IL-6) em sobrenadantes de culturas de células mononucleares do sangue periférico (PBMC) de pacientes com hanseníase, antes e 30 dias após a aplicação de BCG-id. PBMC isoladas pelo gra- 
diente Ficoll-Hypaque foram cultivadas na presença de Con-A ou LPS e BCG. Os sobrenadantes foram coletados para quantificação das citocinas pelo método ELISA. Os resultados mostraram produção aumentada das citocinas após a aplicação do BCG-id, na presença dos mitógenos (Con-A ou LPS) e do próprio $\mathrm{BCG}$, em pacientes com hanseníase MB e PB, porém foram estatisticamente significantes os níveis das ci- tocinas TNF $\alpha$ (p:0,039) e IL-6 (p:0,047) produzidos por PBMC de pacientes com hanseníase multibacilar. Esses resultados sugerem que BCG-id induz a ativação da fase inicial da atividade imunecelular (aumento de TNF $\alpha$ e ativação de macrófagos). Logo se pode concluir que o uso de BCG-id está indicado como adjuvante do tratamento da hanseníase, especialmente da hanseníase multibacilar.

\section{AVALIAÇÃo Da PRESENÇA DE FATORES DE RISCO PARA DOENÇA ATEROSCLERÓTICA EM ADULTOS TRABALHADORES DE INDÚSTRIA ALIMENTÍCIA}

\section{Roberta Soares Lara Cassani}

Orientador: Prof. Dr. André Schmidt

Dissertação de Mestrado apresentada em 05/05/2006

O estudo da prevalência de fatores de risco cardiovascular em nosso país apresenta importantes dificuldades em virtude da extensão territorial, que, favorece hábitos de vida distintos conforme a região geográfica, além de diferenças em grupos de uma mesma região de acordo com características sócioeconômicas. A caracterização recente da Síndrome Metabólica (SM) e sua relação com risco cardiovascular aumentado ainda foi pouco estudada na literatura nacional. A identificação da prevalência de alterações de diversas variáveis antropométricas relacionadas a ela e dos fatores de risco cardiovascular consagrados e emergentes constituem o objetivo deste estudo. Foram avaliados 1047 funcionários de ambos os sexos (913 homens e 134 mulheres) de uma indústria alimentícia na cidade de Itu -SP. A idade média foi de $36 \pm 8$ anos. Foi preenchida ficha de coleta de informações sobre dados pessoais e conhecimento de fatores de risco (hipertensão, dislipidemia, diabetes), comportamentos de risco (tabagismo e sedentarismo) e antecedentes familiares. Foi também realizada avaliação clínico-laboratorial, que consistiu no registro de medidas antropométricas, medida da pressão arterial e coleta de sangue capilar para avaliação da colesterolemia total, trigliceridemia e glicemia. Hipertensão arterial sistêmica foi identificada em $28 \%$ da população e $45 \%$ se encontrava na faixa de pré hipertensão. Intolerância à glicose foi sugestiva em $40 \%$ dos funcionários. Hipercolesterolemia foi encontrada em $7 \%$ da população e hipertrigliceridemia em $16 \%$. Antecedentes familiares estavam presentes em $30 \%$ da população e tabagismo corrente foi identificado em $11 \%$. Sedentarismo foi o principal fator de risco identificado (83\%). Sobrepeso foi evidenciado em $63 \%$ da população, sendo $17 \%$ classificados como obesos. Houve importante associação entre incremento nas medidas antropométricas que caracterizam a presença de gordura corporal aumentada e alterações clínico-laboratoriais. Sendo assim, índice de massa corporal e circunferência abdominal aumentados estiveram positivamente $(\mathrm{p}<0,05)$ associados a valores mais elevados de pressão arterial, colesterol total, triglicérides e glicemia. A avaliação conjunta das diversas alterações clínico-laboratoriais de um mesmo indivíduo permitiu, utilizando os critérios atuais para diagnóstico de Síndrome Metabólica (SM), identificá-la em $3 \%$ das mulheres e $5,5 \%$ dos homens, mesmo sem utilizar a medida do colesterol de alta densidade (HDLcolesterol) e a glicemia de jejum. Além disso, percentual significante (23\%) dos indivíduos apresentava dois marcadores para a SM, indicando que subestimação pode ter ocorrido Em conclusão, a prevalência de fatores de risco cardiovascular isoladamente é relevante na população avaliada, resultando em significativo percentual de casos de SM decorrentes da presença concomitante de vários deles. Foi identificada ainda relação direta e positiva entre as medidas antropométricas e variáveis bioquímicas. Estas, por sua vez, poderiam ser importantes indicadores precoces de propensão à SM e DCA, o que permitiria intervenções com o objetivo de se evitar um aumento de sua prevalência em nosso meio. 


\section{ESTUDO SOBRE A CORRELAÇÃO ENTRE GRAVIDADE DA DEMENCIA SENIL TIPO ALZHEIMER, NÍVEIS DE HOMOCISTEÍNA PLASMÁTICA E GENÓTIPOS DA METILENOTETRAHIDROFOLATO REDUTASE}

\section{Charlys Barbosa Nogueira}

Orientador: Prof. Dr. Júlio César Moriguti

Tese de Doutorado apresentada em 08/05/2006

Demência senil tipo Alzheimer (DA) é uma doença neurodegenerativa crônica que tem sido associada a uma série de fatores de risco como idade, historia familiar, fatores genéticos e doença vascular cerebral prévia. Fatores de risco passíveis de modificações têm sido bastante estudados e destes destacamos a hiperhomocisteinemia.

A enzima metilenotetrahidrofolato redutase (MTHFR) participa de forma significativa no metabolismo da homocisteína. Alguns polimorfismos no gene codificador desta enzima podem levar a formação de enzimas com atividade reduzida e este fato poderia causar aumento dos níveis de homocisteina. Alguns exemplos destes polimorfismos são C677T, A1298C e G1793A.

Os objetivos desse estudo foram avaliar os níveis de homocisteína sérica, ácido fólico e vitamina $\mathrm{B}_{12}$ em pacientes com diagnóstico de DA provável em diferentes estágios da doença e se polimorfismos no gene MTHFR estão relacionados a esta doença.

Para tanto foi realizado estudo transversal e tipo caso controle, com 77 voluntários, sendo 20 controles cognitivamente normais, 20 com DA leve, 16 com DA moderada e 14 com DA grave segundo critérios da NINCS-ADRDA e DSM-IV, além de 7 pacientes com comprometimento cognitivo leve segundo critérios de Petersen. Os voluntários, após o diagnóstico, foram classificados pela Escala Clínica de demência (CDR).

Os níveis de homocisteína foram significativa- mente maiores entre os doentes (DA leve, moderada e grave) e principalmente entre aqueles com DA moderada e grave em relação aos controles. O risco relativo para DA entre aqueles com hiperhomocisteinemia moderada e intermediaria $(16-100 \mu \mathrm{mol} / \mathrm{L})$ foi de $3,16(1,37-7,28)$ e $2,91(1,42-5,98)$ para DA moderada e grave respectivamente. Os níveis de vitamina $\mathrm{B}_{12}$ e folato foram menores entre os voluntários doentes notoriamente entre aqueles com DA moderada e grave.

As prevalências dos genótipos C677T e G1793A do gene MTHFR não diferiram entre os grupos estudados. O genótipo A1298C, homozigoto para $\mathrm{o}$ alelo menos freqüente (CC), foi mais encontrado entre os voluntários do grupo controle com valor de odds ratio de 0,09 (Intervalo de confiança: 0,01-0,83). Fato que sugere um possível efeito protetor para o desenvolvimento de DA.

Em conclusão, os níveis de homocisteína sérica mostraram-se significativamente maiores entre portadores de doença de Alzheimer, notoriamente entre aqueles com DA moderada e grave. Os níveis de vitamina $\mathrm{B}_{12}$ e folato foram menores entre os voluntários com Alzheimer moderado e grave em relação ao grupo controle, porem em sua maioria dentro dos limites normais. É provável que níveis mais elevados de homocisteína sérica possam estar implicados com uma evolução menos favorável da doença de Alzheimer e, dessa forma, estudos prospectivos buscando elucidar as possíveis relações entre níveis de homocisteína, vitamina $B_{12}$ e folato com déficits cognitivos e evolução para doença de Alzheimer ainda se fazem necessários.

\section{A TÉCNICA dE PUNÇÃo da FíSTULA ARTÉRIO-VENOSA COMO FATOR PREPONDERANTE À ADEQUAÇÃO HEMODIALÍTICA}

\section{Taísa Silva Dias}

Orientador: Prof. Dr. José Abrão Cardeal da Costa Dissertação Mestrado apresentada em 08/05/2006

Objetivos: Aferir através de exames laboratoriais o percentual de recirculação sangüínea dos acessos vasculares (AV) dos pacientes que realizam he- modiálise e, em seguida calcular seus respectivos Kt/ Vs nas diferentes técnicas de punção dos AV definitivos ou portadores de cateteres venosos temporários.

Materiais e Métodos: Participaram do estudo 201 pacientes, que foram classificados de acordo com a técnica utilizada para punção do AV em cinco grupos, destacando-se os seguintes: Grupo 1 (forma clássica de punção, com agulhas em direções opostas, 
sendo a arterial voltada ao membro e a venosa em direção ao coração, e com distância maior ou igual a 5 $\mathrm{cm}$ entre elas), Grupo 4 (agulhas unidirecionais, ambas direcionadas ao coração, porém com distância menor que $5 \mathrm{~cm}$ entre elas) e Grupo 5 (portadores de cateter duplo lúmen). Foram coletadas no total 5 amostras de sangue para análise de uréia: pré e pós-hemodiálise e, para o cálculo do percentual de recirculação sangüínea, conforme a proposta de D’Ávila (1990). Para cálculo do Kt/V foi utilizado o método de Daurgidas II ou Segunda Geração, que foi comparado posteriormente à fórmula de Jindal e Kt/V total.

Resultados: $O$ grupo 1 apresentou o menor índice de recirculação sangüínea $(9,4 \pm 5,56 \%)$ e melhor Kt/V $(1,68 \pm 0,36)$. Sendo que o grupo 4 apresen- tou os piores índices com relação a recirculação $(19,75 \pm 5,08 \%)$ e $\mathrm{Kt} / \mathrm{V}(1,16 \pm 0,26)$. Todos os grupos, com exceção do grupo 5, quando comparados ao grupo 4 obtiveram diferença estatística $(\mathrm{p}<0,05)$ para os parâmetros recirculação e Kt/V para os métodos de Daurgidas II e Jindal. Porém, em relação ao Kt/V total, só obteve valor de $\mathrm{p}<0,05$ quando comparado o grupo 1 com o grupo 4 .

Conclusão: A punção do acesso vascular deve ser considerada como fator indispensável para minimizar a recirculação sangüínea e obter melhores resultados quanto à adequação hemodialítica. Conforme os resultados obtidos, a inserção das agulhas no mesmo sentido e com distância menor que $5 \mathrm{~cm}$ entre elas deve ser evitada.

\section{ESTUDO DA CORRELAÇÃO ENTRE AS ANORMALIDADES DA PERFUSÃO MIOCÁRDICA E A DISFUNÇÃO VENTRICULAR ESQUERDA EM VÍTIMAS DE ESCORPIONISMO MODERADO OU GRAVE}

\section{Alexandre Baldini de Figueiredo \\ Orientador: Prof. Dr. Marcus Vinícius Simões \\ Dissertação de Mestrado apresentada em 15/05/2006}

O presente estudo objetivou investigar a participação de distúrbios da perfusão miocárdica no mecanismo fisiopatológico da disfunção cardíaca em pacientes vítimas de escorpionismo moderado ou grave, correlacionando-os com achados clínicos, eletrocardiográficos, com os níveis de enzimas cardíacas e com a função contrátil global e regional do ventrículo esquerdo. Objetivou ainda investigar a evolução temporal dos distúrbios de perfusão miocárdica e da função contrátil do ventrículo esquerdo em um período de acompanhamento de duas semanas. Foram prospectivamente estudados 15 pacientes vítimas de escorpionismo moderado $(n=3)$ ou grave $(n=12)(7 \pm 4$ anos, 9 masculinos). Os pacientes realizaram cintilografia de perfusão miocárdica com administração de $99 \mathrm{mTc}-$ Sestamibi em repouso dentro de 72 horas (avaliação inicial) e 15 dias (seguimento) após o acidente escorpiônico, sendo que as imagens tomográficas foram adquiridas sincronizadas com ECG (Gated SPECT) para avaliação simultânea da perfusão e da contratilidade do ventrículo esquerdo. Dois observadores independentes avaliaram através de escore visual semiquantitativo a perfusão $(0=$ normal, $1=$ redução discreta, $2=$ redução moderada, $3=$ redução intensa e $4=$ ausente) e a mobilidade segmentar $(0=$ normal, $1=$ hipocinesia discreta, $2=$ hipocinesia moderada, $3=$ hipocinesia intensa e 4=acinético) do ventrículo esquerdo, utilizando modelo que divide a parede ventricular esquerda em 17 segmentos. Para cada paciente foram calculados escores somados de perfusão e mobilidade. A fração de ejeção do ventrículo esquerdo (FEVE) foi calculada automaticamente pelo software "Quantitative Gated Spect (QGS)". Dos 15 pacientes incluídos no estudo, $12(80 \%)$ apresentaram significativas alterações da contratilidade e da perfusão miocárdica nos estudos iniciais. O escore somado de perfusão médio na avaliação inicial foi de $12.53 \pm 7.31$, o de mobilidade foi de $17 \pm 12.84$ e a média da FEVE foi de 44,64 \pm $16,03 \%$. Houve correlação positiva entre o escore somado de perfusão e o escore somado de mobilidade $(\mathrm{r}=0.68 ; \mathrm{p}=0.005)$ e correlação negativa entre o escore somado de perfusão e a FEVE $(\mathrm{r}=-0.75 ; \mathrm{p}=0.0021)$. Observou-se também correlação positiva entre os valores do escore somado de perfusão e os níveis de pico de CKMB ( $r=0,61 ; p=0,0152)$ e ainda associação entre os valores do escore somado de perfusão e a ocorrência de alterações eletrocardiográficas significativas ( $p=0,0440$ teste exato de Fisher). Os estudos de seguimento mostraram recuperação significativa da função contrátil global (média da FEVE de $68.92 \pm 9.51, \mathrm{p}=0.0002$ teste $\mathrm{t}$ pareado), segmentar (escore somado de mobilidade $2.60 \pm 3.09, \mathrm{p}=0.0009$ teste t pareado) e da perfusão do ventrículo esquerdo (escore somado de perfusão $3.73 \pm 3.33, \mathrm{p}=0.0003$ teste $\mathrm{t}$ pareado). A melhora da FEVE correlacionou-se positivamente com a melhora do escore somado de perfu- 
são $(r=0.72 ; p=0.0035)$. Concluindo, as alterações perfusionais miocárdicas são comuns no envenenamento escorpiônico grave e mostram correlação topográfica em extensão e gravidade com a disfunção sistólica ventricular global e segmentar. A recuperação da fun- ção contrátil do ventrículo esquerdo correlaciona-se com a reversibilidade dos defeitos perfusionais. Estes achados sugerem a participação de alterações perfusionais miocárdicas no mecanismo fisiopatológico desta forma de insuficiência ventricular aguda.

\section{ESTADO NUTRICIONAL EM RELAÇÃO AO MAGNÉSIO EM PACIENTES COM REDUÇÃO DA SUPERFÍCIE ABSORTIVA INTESTINAL}

\section{Flávia Junqueira de Souza}

Orientador: Prof. Dr. Hélio Vannucchi

Dissertação de Mestrado apresentada em 15/05/2006

A Síndrome do Intestino Curto (SIC) é definida como um estado que muitas vezes segue uma ressecção extensa do intestino delgado causando perda excessiva de micronutrientes incluindo magnésio. Por outro lado, o tratamento cirúrgico da obesidade envolve técnicas disabsortivas, como a derivação gastrojejunal em Y-de-Roux (cirurgia de Capella), que podem acarretar deficiências nutricionais também envolvendo este mineral. $\mathrm{O}$ magnésio $(\mathrm{Mg})$, quarto cátion mais abundante no corpo humano e segundo mais abundante no fluido intracelular, participa de várias reações bioquímicas, sendo cofator de enzimas como a creatina quinase (CK). Embora o nível de Mg seja mais comumente determinado no soro, a análise do conteúdo intracelular é o melhor método. O objetivo do presente estudo foi avaliar o estado nutricional em relação ao $\mathrm{Mg}$ em pacientes com superfície absortiva intestinal reduzida. Os pacientes foram classificados em Grupo Enterectomizado (GE), Grupo Bariátrica (GB) e Grupo Controle (GC). A ingestão alimentar de Mg foi analisada por meio de Recordatório de $24 \mathrm{hs}$ e amostras sanguíneas foram coletadas para dosagem de Mg plasmático, eritrocitário por espectrometria de absorção atômica e dosagem de CK por espectrometria em modo cinético. A ingestão de $\mathrm{Mg}$ esteve abaixo da EAR para todos os grupos $(\mathrm{GE}=121,21 \pm 61,0 \mathrm{mg} / \mathrm{dia}$; $\mathrm{GB}=128,07 \pm 62,8 \mathrm{mg} / \mathrm{dia}$ e $\mathrm{GC}=123,07 \pm 45,74 \mathrm{mg} /$ dia), sem diferença significativa $(p>0,05)$. A porcentagem de adequação média em relação a EAR também se mostrou inadequada para os três grupos ( $\mathrm{GE}=$ $38,34 \pm 17,79 \% ; \mathrm{GB}=43,91 \pm 17,78 \%$ e GC $=41,94 \pm$ $17,8 \%)$, sem diferença estatisticamente significativa $(\mathrm{p}>0,05)$. Valores médios abaixo das concentrações normais de $\mathrm{Mg}$ plasmático foram observados somente para GE $(1,19 \pm 0,21 \mathrm{mEq} / \mathrm{L})$, com diferença significativa entre GE e GB $(1,53 \pm 0,22 \mathrm{mEq} / \mathrm{L})$ e entre GE e GC $(1,57 \pm 0,13 \mathrm{mEq} / \mathrm{L})(\mathrm{p}<0,05)$. Observou-se entre os pacientes avaliados, hipomagnesemia em $88,9 \%$ dos pacientes no GE, $41,7 \%$ no grupo GB e em quatro indivíduos no Grupo Controle $(28,6 \%)$. Nenhuma diferença estatisticamente significativa para $\mathrm{Mg}$ eritrocitário foi encontrada entre os grupos $(\mathrm{p}>0,05)$ e os valores encontraram- se, em média, dentro dos limites normais $(\mathrm{GE}=4,03 \pm 1,24 \mathrm{mEq} / \mathrm{L} ; \mathrm{GB}=4,56 \pm$ $1,35 \mathrm{mEq} / \mathrm{L}$ e $\mathrm{GC}=4,34 \pm 0,48 \mathrm{mEq} / \mathrm{L})$. Para cada amostra avaliada, valores abaixo da normalidade foram observados em três indivíduos no grupo GE $(33,3 \%)$ e em um paciente no Grupo Bariátrica $(8,3 \%)$. Os valores médios para a atividade da CK também se mostraram normais $(\mathrm{GE}=60,66 \pm 31,43 \mathrm{U} / \mathrm{L}$; $\mathrm{GB}=$ $47,96 \pm 23,94 \mathrm{U} / \mathrm{L}$ e GC $=78,47 \pm 33,82 \mathrm{U} / \mathrm{L}) \mathrm{com}$ diferença significativa entre GB e GC ( $p<0,05)$. Também foram observados valores abaixo dos limites de referência em um paciente no grupo GE $(11,1 \%)$ e em um no grupo GB $(8,3 \%)$. Concluiu-se que o estado nutricional em relação ao magnésio mostrou-se alterado nos pacientes com redução da capacidade absortiva intestinal para todos os parâmetros avaliados.

\section{RELEVÂNCIA CLÍNICA DA CARACTERIZAÇÃO GENOTÍPICA gB DO CITOMEGALOVÍRUS (CMV) NA INFECÇÃO CONGÊNITA}

\section{Lauro Juliano Marin}

Orientadora: Profa. Dra. Aparecida Yulie Yamamoto

Tese de Doutorado apresentada em 18/05/2006
Introdução: A caracterização genotípica de cepas do CMV que causam a infecção congênita tem recebido atenção devido a estratégias de prevenção 
por meio de vacinas. Os genótipos gB podem ter diferentes frequiências de acordo com a região geográfica e influenciar nas características da doença.

Objetivos: 1- Estimar a prevalência dos genótipos gB de cepas do CMV em recém-nascidos (RN) com infecção congênita, estudando a relação desses genótipos com a ocorrência de infecção sintomática. 2- Avaliar a co-infecção com diferentes cepas virais nas crianças infectadas ao nascimento e durante o primeiro ano de vida.

Métodos: Setenta e sete recém-nascidos $(\mathrm{RN})$ com infecção congênita por CMV foram estudados, sendo 19/77 (25\%) sintomáticos e 58/77 (75\%) assintomáticos. Amostras de urina e saliva foram obtidas de todos RN e amostras de sangue capilar em papel filtro de $45 \mathrm{RN}$. O diagnóstico de infecção congênita por CMV foi baseado na detecção do DNA viral pela reação de amplificação gênica em cadeia da polimerase e confirmado pelo isolamento viral em pelo menos duas amostras de urina e/ou saliva coletadas até 3 semanas de vida. A análise dos genótipos foi baseada no polimorfismo do fragmento de restrição do amplificado do gene codificador da glicoproteína B. Amostras seqüenciais de urina e/ou saliva foram obtidas de 48 crianças infectadas durante o primeiro ano de vida e monitorizadas para determinação dos genótipos gB. A reinfecção foi definida se a análise das cepas virais do CMV mostraram genótipos $\mathrm{gB}$ diferentes quando comparada à última detecção em pelo menos duas amostras seriadas.
Resultados: Dentre os RN, a distribuição dos genótipos foi gB1: 25/77 (32,5\%); gB2: 32/77 (41,5\%); gB3: 20/77 (26\%); gB4: 0/77 (0\%). Não houve predomínio de nenhum genótipo ( $\mathrm{p}=0,39)$. $\mathrm{O}$ mesmo genótipo foi encontrado em diferentes sítios corporais (urina, saliva e sangue) de cada RN infectado. Não foi observada nenhuma associação entre a ocorrência de infecção sintomática pelo CMV e os genótipos virais $(\mathrm{p}=0,17)$. Durante o seguimento de 3 a 20 meses (mediana=11 meses), genótipos diferentes foram identificados em apenas uma criança $(2.1 \%)$, sugerindo reinfecção com uma nova cepa. Nas 47 crianças remanescentes, um único genótipo viral identificado ao nascimento foi detectado em todas as amostras subsequentes.

Conclusões: Uma distribuição similar dos genótipos gB1, gB2 e gB3 e uma baixa freqüência de gB4 foi observada em recém-nascidos infectados congenitamente nesta região do Brasil. A diferença da distribuição comparada aos estudos em outros países pode estar relacionada com a distribuição geográfica das cepas virais. A não associação dos genótipos $\mathrm{gB}$ com a expressão clínica da doença congênita sugere que a glicoproteína $B$ não é o único fator responsável pela virulência de cada cepa. Um único genótipo viral foi responsável pela infecção em cada recém nascido ao nascimento. A reinfecção precoce pelo CMV não é um evento freqüente em crianças portadoras de infecção congênita, mesmo numa população com alta exposição ao CMV.

\section{AMBIENTE DIGITAL PARA LAUDO RADIOLÓGICO SEM FILME}

\section{Alexander Antonio Benedicto}

Orientador: Prof. Dr. Paulo M. de Azevedo Marques Dissertação de Mestrado apresentada em 19/05/2006

A integração dos diversos sistemas que constituem um serviço de radiologia, juntamente com o PACS, é o principal objetivo dos estudos na área tecnológica da radiologia. Com o resultado desta integração, é possível criar um ambiente digital para radiologia sem filme, onde os sistemas convencionais de tela/ filme podem ser substituídos ou reduzidos em grande escala. As vantagens que um ambiente sem filme proporciona a um departamento de radiologia são inúmeros, considerando desde o fato da redução da quantidade de radiação que o paciente receberá utilizando os sistemas de CR e DR, como também a eficiência e flexibilidade no fluxo de trabalho destes tipos de serviços. A integração sendo tratada como uma camada intermediária entre esses diversos sistemas, garante a comunicação e troca de informações entre estes e os sistemas heterogêneos, possibilitando a criação de um serviço "filmless" sem elevar muito os custos de aquisição de novos equipamentos. Além dos equipamentos, é possível também fazer o interfaceamento entre os sistemas que manipulam as informações referentes aos pacientes, exames e os demais dados relacionados ao sistema médico e hospitalar. Para garantir toda esta integração, são utilizados os padrões de mercado como o DICOM e o HL7, seguindo os critérios estabelecidos pelo modelo IHE. Desta forma, criando um ambiente digital robusto e escalável que garanta a integração de todos os sistemas necessários para substituir a utilização de filmes papéis. 


\section{CARACTERÍSTICAS EPIDEMIOLÓGICAS, CLÍNICAS E LABORATORIAIS DA PARACOCCIDIOIDOMICOSE EM PACIENTES CO-INFECTADOS PELO VÍRUS DA IMUNODEFICIÊNCIA HUMANA}

\author{
Karen Mirna Loro Morejón \\ Orientador: Prof. Dr. Roberto Martinez \\ Dissertação de Mestrado apresentada em 19/05/2006
}

Introdução: A paracoccidioidomicose (PBmicose) é a micose profunda mais freqüente na América Latina, com maior incidência no Brasil, especialmente no Estado de São Paulo, estimada de 1-3/100.000 habitantes/ano em áreas endêmicas. O Hospital das Clínicas da Faculdade de Medicina de Ribeirão Preto - USP (HCFMRP-USP) é o centro com maior número de casos da co-infecção HIV-1/P. Brasiliensis.

Objetivos: Analisar pacientes com PBmicose infectados e não infectados pelo HIV-1 em seus aspectos epidemiológicos, clínicos, laboratoriais, terapêuticos e evolutivos para determinar as características peculiares dos pacientes HIV positivos.

Casuística e Métodos: Estudo retrospectivo, caso controle 1:2, onde foram observados todos os pacientes HIV positivos infectados pelo Paracoccidioides brasiliensis (P. brasiliensis), acima de 16 anos, seguidos no HCFMRP-USP. Os controles eram pacientes com PBmicose, porém soronegativos para o HIV-1, selecionados através de sorteio. A análise dos dados foi realizada com o programa Stata, versão 8.

Resultados: Foram avaliados 159 pacientes com PBmicose, 53 infectados pelo HIV-1 e 156 não infectados. A média de idade foi de 33.5 anos (16-57 anos) para os pacientes HIV positivos e 45.2 anos (1877 anos) para os pacientes HIV negativos. A infecção pelo HIV-1 foi diagnosticada no momento da infecção fúngica em 43,4\% dos pacientes. Os pacientes HIV positivos apresentaram um maior envolvimento hepá- tico, esplênico e cutâneo $(\mathrm{p}<0.001)$. A determinação inicial de anticorpos pela contraimunoeletroforose (CIE) foi realizada em 152 pacientes (50 pacientes HIV positivos e 102 pacientes HIV negativos). Em 16 casos o exame foi não reagente (12 pacientes HIV positivos e 4 HIV negativos). A média de CIE inicial foi 378.88 (2 - 4096) para os pacientes HIV positivos e $1.341,05$ (1 - 65.536) para os pacientes HIV negativos. A maioria dos pacientes de ambos os grupos apresentava exame histológico de algum positivo para $P$. brasiliensis. A radiografia de tórax inicial estava alterada na maior parte dos casos em ambos os grupos. A média da contagem de linfócitos T CD4 + dos pacientes do primeiro grupo foi de $93.9+129.0$ céls $/ \mathrm{mm}^{3}(0.76-480)$. O tratamento inicial foi realizado com cotrimoxazol em 45.3\% dos pacientes HIV positivos e em $63.2 \%$ dos pacientes HIV negativos. Anfotericina B foi o tratamento inicial para $22,6 \%$ dos pacientes do primeiro grupo e para 7,5\% do segundo grupo. Ao final de 24 meses de seguimento, $60,7 \%$ dos pacientes do primeiro e 79,1\% do segundo grupo haviam obtido cura clínica.

Conclusões: A análise dos dados leva-nos a concluir que a PBmicose tende a ser disseminada em pacientes com sorologia positiva para o HIV-1, principalmente em presença de severa imunodepressão, porém com resposta clínica satisfatória ao tratamento medicamentoso. Esses dados permitem sugerir que todos os pacientes com PBmicose disseminada, em áreas endêmicas, sejam investigados para causas de imunodeficiência, inclusive o HIV-1. Essa é maior série relatada de pacientes com essa co-infecção. Nossos dados sugerem que P. brasiliensis é oportunista em pacientes infectados pelo HIV-1.

\section{ESTUDO DA MODULAÇÃO AUTONÔMICA DA FREQÜÊNCIA CARDÍACA EM REPOUSO E SUA RELAÇÃO COM A CAPACIDADE AERÓBIA EM EXERCÍCIO DINÂMICO NA HIPERTENSÃO ARTERIAL ESSENCIAL}

\section{Renata Torres Kozuki}

Orientador: Prof. Dr. Lourenço Gallo Junior

Dissertação de Mestrado apresentada em 19/05/2006

Sabe-se que a disfunção autonômica eferente e a redução da capacidade aeróbia são fatores de ris- co independentes para a morte súbita em pacientes cardiopatas. Além disso, a hipertensão arterial essencial geralmente se acompanha de disfunção autonômica, ainda não suficientemente caracterizada. $O$ principal objetivo deste estudo é correlacionar a resposta autonômica do coração em repouso, com a respectiva 
capacidade aeróbia, obtida através da medida do limiar de anaerobiose ventilatório (LAV). Foram estudados 18 pacientes hipertensos do sexo masculino, com idade (média \pm DP) de $42 \pm 7$ anos, os quais foram pareados por sexo, idade, características antropométricas e grau de sedentarismo, com um grupo sadio de $38 \pm 9$ anos. Os hipertensos apresentavam apenas a forma idiopática da doença, de grau leve a moderado, caracterizada por avaliação clínica e exames subsidiários (com pequeno grau de hipertrofia ventricular esquerda ao ecocardiograma e/ou eletrocardiograma). A retirada da medicação hipotensora, nos hipertensos em tratamento (55\%), ocorreu 15 dias antes da realização da monitorização ambulatorial (24 h) da pressão arterial (MAPA) e dos testes autonômicos e de esforço. A variabilidade da frequiência cardíaca (VFC), calculada no repouso supino, repouso sentado e teste de inclinação passiva, foi obtida no domínio do tempo, a partir dos índices RMSM e RMSSD dos intervalos R-R (iR-R) em ms, e no domínio da freqüência, por meio da obtenção da densidade do espectro de potência, utilizando-se a Transformada Rápida de Fourier, obtendo-se os componentes espectrais de alta freqüência (AF) e baixa frequiência (BF), também expressos em unidades normalizadas (AFun e BFun) e a razão
BF/AF. Ainda foram calculados os índices e deltas da manobra de Valsalva. O teste ergoespirométrico, em cicloergômetro, utilizando-se um protocolo do tipo rampa, foi aplicado aos dois grupos. As variáveis ventilatórias foram obtidas, de respiração à respiração, usando-se o sistema CPX/D MedGraphics. O LAV, expresso em potência (Watts) e consumo de oxigênio $\left(\mathrm{VO}_{2}\right)$ em litros por minuto, foi determinado visualmente pela perda da linearidade das respostas ventilatórias. A modulação autonômica da frequiência cardíaca (FC) não apresentou diferenças entre os dois grupos, exceto na posição vertical passiva, onde o RMSM, RMSSD e BF foram estatisticamente maiores no grupo controle $(\mathrm{p}<0,05)$. Durante a manobra de Valsalva não se observou diferença entre os grupos. O LAV, expresso em $\mathrm{VO}_{2} / \mathrm{kg}$ e potência, foi menor no grupo hipertenso $(\mathrm{p}<0,05)$. O incremento de $\mathrm{FC}$, do repouso ao ponto do LAV, foi menor no grupo hipertenso do que no controle $(\mathrm{p}<0,05)$. Conclui-se, que em repouso a modulação autonômica está normal ou pouco alterada nos hipertensos. Em exercício, a capacidade aeróbia foi menor no grupo hipertenso do que no controle. Não foi possível documentar qualquer relação entre as magnitudes da VFC em repouso e da capacidade aeróbia em exercício.

\section{ESTUDO COMPARATIVO DO EFEITO DO EXERCÍCIO AERÓBIO CONTÍNUO E DO EXERCÍCIO RESISTIDO EM PORTADORES DE DIABETES TIPO 2}

\section{Cássio Ricardo Vaz Fiani}

Orientador: Prof. Dr. Milton César Foss

Dissertação de Mestrado apresentada em 22/05/2006

O Diabetes Mellitus é uma das principais síndromes de evolução crônica que acomete o homem moderno em qualquer idade, condição social e localização geográfica (BELFORT \& OLIVEIRA, 2001). O presente estudo tem como objetivo comparar o efeito do exercício aeróbio contínuo e do exercício resistido, sobre variações na taxa glicêmica capilar, na hemoglobina glicada, no peso corporal e na pressão arterial de pacientes portadores de diabetes mellitus tipo 2 . Com um nível de significância $\alpha<0,05$, observamos que não há efeito de interação entre o fator Grupo (resistido e aeróbio) com o fator Número de Treinos. Também não foi verificado efeito do fator Número de Treinos nas diferenças entre a pressão arterial pré e pós-treinamento (valor-p = 0196). Por outro lado o fator
Grupo (resistido e aeróbio) apresenta significância (valor-p $=0.022$ ) na resposta, ou seja, existe diferença estatística entre as médias das respostas (diferenças entre a pressão arterial pré e pós-treinamento) para o grupo resistido e aeróbio. Analisando o fator Grupo observa-se que o grupo cardiovascular apresentou, em média, maior diferença na pressão arterial pré e póstreinamento, ou seja, um aumento na pressão arterial após o treino. A média das diferenças de taxa de glicemia pré e pós-treinamento apresentou-se maior no grupo cardiovascular. Os dois grupos apresentam valores extremos, ou seja, valores muito afastados da maioria dos dados. Com um nível de significância $\alpha<0,05$, observamos que não há efeito de interação entre o fator Grupo (resistido e aeróbio) com o fator Número de Treinos. Dessa forma, prosseguimos com a análise para verificar os efeitos principais dos fatores. Não foi verificado efeito do fator Número de Treinos nas diferenças entre as taxas de glicemia pré e pós-trei- 
namento (valor-p $=0,661$ ). Por outro lado o fator Grupo (resistido e aeróbio) apresenta significância leve (valor-p $=0.05$ ) na resposta, ou seja, existe diferença estatística entre as médias das respostas (diferenças entre as taxas de glicemia pré e pós-treinamento) para o grupo resistido e aeróbio. Analisando os níveis do fator Grupo, que apresentou diferença estatística entre as médias das respostas, observa-se que o grupo cárdio apresentou, em média, maior diferença nas taxas de glicemia pré e pós-treinamento, ou seja, maior queda na taxa de glicemia após o treino. Com um nível de significância $\alpha<0,05$, observamos que não há efeito de interação entre o fator Grupo (resistido e aeróbio) com o fator Número de Treinos. Dessa forma, prosseguimos com a análise para verificar os efeitos principais dos fatores. Foi verificado efeito do fator Número de Treinos nas diferenças entre o peso corporal pré e pós protocolo (valor-p $=0,027$ ), ou seja, existe diferença estatística entre as médias das respostas (diferenças entre os pesos corporais dos indivíduos com maior número de treinos). A média das diferenças da hemoglobina glicada pré e pós protocolo apresentou-se maior no grupo resistido. Com um nível de significância $\alpha<0,05$, observamos que não há efeito de interação entre o fator Grupo (resistido e aeróbio) com o fator Número de Treinos. Dessa forma, prosseguimos com a análise para verificar os efeitos principais dos fatores. Não foi verificado efeito do fator Número de Treinos nas diferenças entre a Hemoglobina Glicada pré e pós-protocolo $(\mathrm{p}=0,142)$, e também não verificamos efeito do fator Grupo (resistido e aeróbio) nas diferenças de encontradas, ou seja, não existe diferença estatisticamente significante entre as médias das respostas. Podemos através dos dados obtidos concluir que os dois protocolos estudados promovem melhorias na glicemia capilar, no peso corporal, e na hemoglobina glicada. Concluímos também que os exercícios aeróbios possuem uma condição mais hipoglicemiante que os resistidos, mas levam a uma maior alteração da pressão arterial durante a execução do protocolo.

\section{EFEITOS OXIDATIVOS E GLICÊMICOS CAUSADOS PELO EXERCÍCIO EXCES- SIVO EM RATOS SUPLEMENTADOS COM VITAMINA E OU CARNITINA}

\section{Sérvio Antônio Bucioli}

Orientador: Prof. Dr. Helio Vannucchi

Dissertação de Mestrado apresentada em 22/05/2006

A amenização de efeitos oxidativos dos radicais livres em exercícios de exaustão, e a manutenção da glicemia, são parâmetros para a melhoria do desempenho em atletas, no entanto, na busca de cada vez maior de resultados ou de estética a suplementação tem sido muito utilizada, principalmente de antioxidantes como a vitamina $E$ e aminoácidos como carnitina que também tem sua eficiência referenciada como antioxidante nos seus possíveis efeitos biológicos, assim o objetivo deste estudo foi avaliar os efeitos oxidativos e glicemicos da vitamina E e da carnitina após a aplicação de um protocolo de exercício de exaustão em ratos. Foram utilizados 32 ratos jovens Wistar divididos em 4 grupos iguais com dieta da NUVITAL $®$ e água a vontade: GNSE (Grupo Normal Sem Exercício) Grupo Controle (GC), Carnitina (GK) e Vitamina E (GV), onde $5 \mathrm{mg} / \mathrm{kg}$ de salina, carnitina e vitamina $\mathrm{E}$ foram sucessivamente ministradas durante 7 dias por cateter intra-gastrico. Ao final os animais dos grupos GC, GK e GV foram submetidos a um exercício de natação até a exaustão. Sangue e o rim foram coletados para verificação de Substâncias Reativas ao Ácido Tiobarbitúrico (SRATB) por MDA, Glutationa Reduzida (GSH) e níveis de vitamina E no tecido renal e níveis plasmáticos de carnitina e glicemia. Os dados estatísticos foram analisados pelo Teste de Kruskal-Wallis com pós-teste de Dunn no programa GrafhPad InStat com $\mathrm{p}<0,05$. 0s animais não apresentaram diferenças estatísticas na curva de peso entre os grupos. Os animais mostraram diferenças $(\mathrm{p}<0,05)$ quanto às concentrações renais de vitamina $\mathrm{E}(\mathrm{GNSE}=23,8 \pm 5,91 ; \mathrm{GC}=27,9 \pm 2,25 ; \mathrm{GK}=$ $27,2 \pm 4,26 ; \mathrm{GV}=42,85 \pm 3,6)$, nas concentrações plasmáticas de carnitina e os (GNSE $=17,4 \pm 3,38$; $\mathrm{GC}=14,9 \pm 1,95 ; \mathrm{GK}=41,3 \pm 5,66 ; \mathrm{GV}=21,61 \pm 3,7)$ nas concentrações de MDA no tecido renal $(\mathrm{GNSE}=$ $0,16 \pm 0,02 ; \mathrm{GC}=0,34 \pm 0,07 ; \mathrm{GK}=015 \pm 0,02 ; \mathrm{GV}=$ $0,10 \pm 0,01)$ nas concentrações renais de glutationa $(\mathrm{GNSE}=22,7 \pm 3,7 ; \mathrm{GC}=22,9 \pm 2,0 ; \mathrm{GK}=51,6 \pm 5,9$; $\mathrm{GV}=57,7 \pm 8,8)$ e os níveis de glicemia plasmática $(\mathrm{GNSE}=96,9 \pm 5,4 ; \mathrm{GC}=83,6 \pm 7,9 ; \mathrm{GK}=150,4 \pm$ $10,9 ; \mathrm{GV}=163,4 \pm 5,2)$. Estes resultados mostram que com a suplementação tanto a vitamina E no tecido 
renal como a carnitina no plasma mantém seus níveis superiores aos normais, mesmo com a aplicação de um protocolo de exercício. Neste estudo a suplementação de carnitina mostrou ser eficiente na redução da peroxidação lipídica, no entanto o grupo suplemen- tado com vitamina $\mathrm{E}$ apresentou as menores índices de MDA. Quanto à glicemia tanto a carnitina quanto a vitamina $\mathrm{E}$ demonstraram manter aumentados os níveis de glicemia plasmática mesmo com a aplicação de um protocolo de exercício de exaustão.

\section{ANTICORPOS NEUTRALIZANTES E DETECÇÃO QUANTITATIVA DO CITOME- GALOVIRUS (CMV) EM MÃES TRANSMISSORAS E NÃO TRANSMISSORAS DA INFECÇÃO CONGÊNITA}

Neusa Regina Pires Barbieri

Orientadora: Profa.Dra. Aparecida Yulie Yamamoto

Tese de Doutorado apresentada em 01/06/2006

Introdução: A imunidade humoral contra o CMV em gestantes previamente soropositivas pode desempenhar um papel importante no controle da reativação viral, prevenindo a ocorrência da infecção congênita. Não existem estudos sobre a resposta dos anticorpos neutralizantes específicos contra o CMV em gestantes brasileiras, numa população lcom elevada taxa de soroprevalência. Adicionalmente, mulheres com imunidade preconcepcional albergam o CMV em sítios de latência ainda não conhecidos, responsáveis pela transmissão da infecção ao feto. A replicação viral em sítios acessíveis, tais como o leite materno, presumivelmente reflete a ocorrência de reativação viral durante a gestação e pode ter correlação com a transmissão da infecção congênita.

Objetivos: 1- Comparar a resposta dos anticorpos neutralizantes contra o CMV em amostras séricas obtidas no início da gestação e no momento do parto em mães que tiveram filhos infectados congenitamente (transmissoras, T) e mães soropositivas para CMV de crianças não infectadas (não transmissoras, NT). 2- Investigar a influência de diferentes cepas do CMV na variação dos títulos dos anticorpos neutralizantes. 3- Avaliar a cinética da resposta dos anticorpos neutralizantes contra o CMV durante a gestação em mães T e NT. 4- Comparar a carga viral do CMV no leite de mães que transmitiram e não transmitiram a infecção aos seus filhos.

Métodos e desenho do estudo: Foram incluídas mães de recém-nascidos (RN) infectados congenitamente pelo CMV (transmissoras -T) e identificados em um programa de triagem neonatal de 4439 RN (50 infectados; incidência $=1,1 \%$ ). Para cada caso-índice, foram incluídas duas mães soropositivas para o CMV de RN não infectados; foram avaliadas 47 mães transmissoras e 94 mães não transmissoras. Soros maternos foram obtidos nas primeiras semanas de gestação (mediana $=13$ semanas) e no momento do parto. A atividade neutralizante dos anticorpos maternos contra a cepa AD169 e contra os isolados de RN infectados foi avaliada através de um teste de microneutralização pela redução do efeito citopático. As amostras de leite materno das mães T e NT foram obtidas imediatamente após o parto (mediana $=3$ dias) e submetidas a reação de amplificação gênica da polimerase qualitativa (PCR) para a detecção do DNA viral. As amostras positivas foram quantificadas pela PCR quantitativa em tempo real utilizando o corante fluorescente SYBR Green I com iniciadores que amplificam uma região do gene codificador da glicoproteína B (gB). Todas as 26 de 47 mães T e 47 das 91 NT que tinham amostras de soros disponíveis no início da gestação (mediana=13 semanas) apresentavam anticorpos específicos anti-CMV. Baixos títulos de anticorpos neutralizantes foram encontrados em mães $\mathrm{T}$ comparado às NT em amostras séricas do início da gestação (média geométrica $=87,5(8-128)$ vs 142 (32256); $\mathrm{p}=0,02)$. Um aumento significativo dos títulos da atividade neutralizantes dos anticorpos foi observado em mães T e NT, durante a gestação; $(\mathrm{p}=0,019)$. Os títulos dos anticorpos neutralizantes de amostras séricas obtidas no momento do parto não apresentaram diferenças significativas entre as mães T e NT $(P=0,16)$. A resposta dos anticorpos neutralizantes maternos contra a cepa AD169 e contra as cepas isoladas de seus respectivos filhos foi similar ( $\mathrm{p}=0,33)$. O DNA viral do CMV foi detectado em 38/44 (86,4\%) mães T e em 29/91 (31,8\%) das NT pela PCR qualitativa ( $<<0,001)$. A carga viral do CMV no leite materno nas mães $T$ foi maior que a obtida em mães NT, sendo a média geométrica de $2,37 \times 10^{2}$ (variação de $2,6 \times 10$ a $2,31 \times 10^{3}$ )

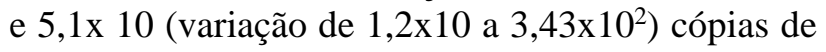
DNA/ $\mu \mathrm{l}(\mathrm{p}=0,004)$, respectivamente. 
Conclusões: Baixos títulos de anticorpos neutralizantes maternos contra o CMV no início da gestação estão associados com a transmissão da infecção congênita. A despeito da heterogeneidade do CMV, os ensaios de neutralização usando a cepa laboratorial AD169 permite uma avaliação adequada da ativi- dade neutralizante contra diferentes cepas do CMV. Cargas virais altas do CMV no leite materno constituem fatores de risco materno para transmissão do CMV ao feto e pode ser marcadores da replicação viral em sítios corporais maternos menos acessíveis, tais como células miometriais.

\section{DIFERENÇAS NA EXPRESSÃO GÊNICA DE CÉLULAS CD34 ${ }^{+}$DE MEDULA ÓSSEA E DE SANGUE DE CORDÃO UMBILICAL}

\author{
Rodrigo Alexandre Panepucci \\ Orientador: Prof. Dr. Marco Antônio Zago \\ Tese de Doutorado apresentada em 01/06/2006
}

Uma maior produção e diversidade de linfócitos T e menor incidência da doença do enxerto contra o hospedeiro (Graft Versus Host Disease, GVHD), são características associadas aos transplantes que utilizam sangue de cordão umbilical (SCU), quando comparados com os que utilizam medula óssea (MO). Estas diferenças se devem em parte às diferenças nas células tronco hematopoéticas $(\mathrm{CTH})$ destes tecidos. Para compreender os mecanismos moleculares responsáveis por estas diferenças intrinsecas, nós analisamos os genes diferencialmente expressos entre as $\mathrm{CTH} \mathrm{CD} 34^{+}$de $\mathrm{MO}$ e SCU. A expressão de aproximadamente 10.000 genes foi comparada pela técnica de análise serial da expressão gênica (SAGE, Serial Analysis of Gene Expression) de células $\mathrm{CD}_{3}{ }^{+}$de $\mathrm{MO}$ e SCU. A expressão diferencial de genes selecionados foi avaliada por PCR em tempo real em amostras adicionais de células $\mathrm{CD} 34^{+}$de $\mathrm{MO}$ $(n=22), S C U(n=9)$ e de sangue periférico mobilizado por G-CSF (SPM, n=6). A grande representatividade de componentes da via NF-kB foi a característica principal encontrada nas CTH de SCU. Uma maior expressão de transcritos codificadores para ativadores (IL1B, TNF e TGFB1), efetores (NFKB2, RELA e RELB) e alvos transcricionais (ICAM1, IL8 e CCL4L) da sinalização por NF-kB foi encontrada nas CTH de SCU e confirmada por PCR em tempo real. Análise adicional nos promotores de 41 genes mais expressos em CTH de SCU revelou um número significativamente maior do que o esperado de elementos cis-regulatórios de NF-kB (presentes em 22 genes).

Nossos resultados apontam para um papel central da via NF-kB nas diferenças moleculares e funcionais observadas entre as CTH de MO e de SCU. Nosso estudo define uma base para estudos futuros e para estratégias potencialmente novas para a manipulação de enxertos de células tronco.

\section{ESTUDO SOBRE A CITOMEGALOVIRUS EM INDIVÍDUOS INFECTADOS PELO HIV}

\section{Aldo de Albuquerque Cunha}

Orientador: Prof. Dr. Luiz Tadeu Moraes Figueiredo Tese de Doutorado apresentada em 02/06/2006

A citomegalovirose é infecção importante nos indivíduos infectados pelo HIV apesar de ter sofrido redução em frequiência com o aparecimento da terapia anti-retrovirus combinada. Neste trabalho estudou-se a infecção e a doença por citomegalovírus (CMV), em indivíduos infectados pelo HIV, detectando-se CMV por métodos virológicos qualitativos e quantita- tivos, bem como, determinando genótipos dos CMV infectantes. Deste estudo, que foi realizado no Centro de Pesquisa em Virologia da FMRP-USP, entre 2002 e 2005, participaram 101 pacientes. Extratos de DNA obtidos do creme leucocitário sanguíneo dos participantes foram submetidas a uma semi-nested PCR, para detecção do genoma de CMV. Trinta e uma amostras de pacientes que tiveram CMV detectado foram submetidos a uma PCR em tempo real quantificadora e a uma genotipagem gB do CMV detectado. Para a PCR quantificadora de CMV realizou-se, com suces- 
so, a clonagem parcial do gene gB de CMV em plasmídio e padronizou-se o método. Os resultados foram analisados buscando associar aos resultados de CMV, dados clínicos dos participantes, como carga viral do $\mathrm{HIV}$, teores de linfócitos $\mathrm{T} \mathrm{CD}_{4}$, regularidade do uso de anti-retrovirais, incidência de infecção oportunista e ocorrência de óbito.

Desta forma, foi possível observar que 31 participantes tiveram CMV detectado em seu creme leucocitário, o que configurou uma positividade de $30,7 \%$. Dois participantes, $6 \%$ dos que tiveram CMV detectado no creme leucocitário, apresentaram quadro sugestivo de citomegalovirose doença. Foram a óbito 16\% dos participantes no grupo que teve CMV detectado no creme leucocitário $(\mathrm{p}=0.007 ; \mathrm{OR}=23,07$, intervalo de confiança $=1.201$ a 443.3). Os 5 óbitos observados ocorreram apenas neste grupo. Os participantes que foram a óbito apresentaram teores de linfócitos $\mathrm{T} \mathrm{CD}_{4}$ abaixo de 55 células $/ \mathrm{mm}^{3}(\mathrm{p}=0,001$; coef $\left._{\text {corr }}=-0,655\right)$. A freqüência de participantes com CMV detectado em creme leucocitário foi significantemente mais elevada entre aqueles no estágio $\mathrm{C}_{3}$ $(\mathrm{p}=0.0052)$. As cargas de CMV de 31 pacientes exibiram teores de 100 a 35000 cópias virais por 1,5 x $10^{5}$ leucócitos. Entre os participantes, foi preponderante na genotipagem de CMV o gB2 $(45,16 \%)$ seguido do gB3 $(35,48 \%)$. O genótipo gB2 de CMV mostrou-se o mais virulento nos pacientes infectados pelo HIV porque, sua frequiência foi significantemente mais elevada nos pacientes que tinham teores de linfócitos $\mathrm{T} \mathrm{CD}_{4}$ abaixo de 200 células $/ \mathrm{ml}$ ( $\mathrm{p}=0,0044$; $\chi 2=10.85), 80 \%$ dos que foram a óbito tiveram este genótipo detectado no creme leucocitário, o mesmo foi associado a cargas de CMV acima de 200 cópias $/ 1,5 \times 10^{5}$ leucócitos $(\mathrm{p}=0,0015 \chi 2=15.47,3)$ e) e a infecção por CMV de genótipo não gB2 mostrou-se um fator preditivo de evolução sem óbito (valor preditivo negativo de $94 \%$ ).

\section{SISTEMA DE GERENCIAMENTO DE IMAGENS PARA AMBIENTE HOSPITALAR COM SUPORTE À RECUPERAÇÃO DE IMAGENS BASEADA EM CONTEÚDO}

\section{Edilson Carlos Caritá}

Orientador: Prof. Dr. Paulo M.de Azevedo Marques

Tese de Doutorado apresentada em 02/06/2006

Neste trabalho é apresentada a implantação de um servidor de imagens médicas com a implementação e integração de módulos para recuperação textual e baseada em conteúdo para o Serviço de Radiodiagnóstico do Hospital das Clínicas da Faculdade de Medicina de Ribeirão Preto (HCFMRP) da Universidade de São Paulo (USP). O sistema permite a aquisição, gerenciamento, armazenamento e disponibilização das informações dos pacientes, seus exames, laudos e imagens através da internet. Os exames radiológicos e suas respectivas imagens podem ser recuperados por informações textuais ou por similaridade do conteúdo pictório das imagens. As imagens utilizadas são de ressonância magnética nuclear e tomografia computadorizada e são geradas no padrão DICOM 3.0. O sistema foi desenvolvido contemplando tecnologias para Web com interfaces amigáveis para recuperação das informações. Ele é composto por três módulos integrados, sendo o servidor de imagens, o módulo de consulta textual e o módulo de consulta por similaridade. Os resultados apresentados indicam que as imagens são gerenciadas e armazenadas corretamente, bem como o tempo de retorno das imagens é clinicamente satisfatório, tanto para a consulta textual como para a consulta por similaridade. As avaliações da recuperação por similaridade apresentam que o extrator escolhido pode ser considerado relevante para separar as imagens por região anatômica.

\section{MÉTOdOS ALTERNATIVOS PARA DIAGNÓSTICO PRECOCE DE PERITONITE BACTERIANA ESPONTÂNEA EM PACIENTES CIRRÓTICOS}

\section{Manuel Antônio Lescano}

Orientador: Prof. Dr. Alex Vianey Callado França

Dissertação de Mestrado apresentada em 12/06/2006
Peritonite bacteriana espontânea (PBE) é freqüente e grave complicação infecciosa do paciente cirrótico com ascite e seu diagnóstico precoce tem 
mudado significativamente o prognóstico desta doença. A citologia do líquido ascítico representa o método padrão ouro no diagnóstico da infecção. Assim, contagem de polimorfonucleares $(\mathrm{PMN}) \geq 250 / \mathrm{mm}^{3}$ é indicativo de presença da infecção no fluido ascítico. No entanto, não é todo serviço de urgência que conta com este método. Fitas reagentes de uroanálise têm mostrado resultados promissores no diagnóstico da PBE em diferentes estudos internacionais. O uso da câmara hematocitométrica para contagem total de leucócitos ainda representa o procedimento padrão dentro da citologia. No entanto, em serviços com alto número de amostras de líquido ascítico a ser estudado, aparelhos automáticos contadores de células sangüíneas têm substituído a câmara hematocitométrica. No presente trabalho, objetivou-se comparar os resultados da fita reagente de uroanálise Multistix 10SG® (negativo, traços, $1+, 2+, 3+$ ) com os da citologia (contagem total de leucócitos com câmara de Neubauer e diferencial com microscopia óptica). Os resultados da fita foram avaliados visualmente e pelo aparelho automático Clinitek $50 ®$. Nos pacientes portadores de PBE, foi realizado o mesmo procedimento 48 horas depois de iniciado o tratamento antibiótico. Foram considerados resultados positivos na fita reagente resultados desde traços até $3+$. Um segundo objetivo da pesquisa foi comparar a acurácia da câmara de Neubauer com o aparelho Coulter T890® na contagem total de leucócitos no lí- quido ascítico. Realizaram-se 107 paracenteses em 58 pacientes cirróticos com ascite durante um período de 7 meses. Foram encontradas 84 amostras de líquido ascítico estéril $\left(\mathrm{PMN}<250 / \mathrm{mm}^{3}\right)$. Todas as amostras apresentaram resultado negativo na fita reagente de uroanálise Multistix 10SG®, quando avaliadas pelo Clinitek 50®. Uma única amostra de líquido ascítico estéril obteve resultado falso positivo quando avaliada visualmente. Foram diagnosticados 12 episódios de PBE em 11 pacientes, mostrando quatro resultados falsos negativos na fita reagente. Foi possível realizar 11 controles terapêuticos. Em três episódios, com $\mathrm{PMN} \geq 250 / \mathrm{mm}^{3}$, a fita mostrou resultados negativos. A fita reagente obteve sensibilidade, especificidade, valor preditivo positivo e negativo de $67 \%, 100 \%, 100 \%$ e $95 \%$, respectivamente, no diagnóstico da PBE. Por outro lado, observou-se uma boa correlação (coeficiente > 0,9) entre a câmara de Neubauer e o Coulter T890® na contagem total de leucócitos no líquido ascítico. Os resultados desta investigação indicam que a fita reagente de uroanálise Multistix 10SG® não mostrou alta sensibilidade, perdendo valor como método de rastreamento no diagnóstico precoce de PBE. Entretanto mostrou alta especificidade, significando que resultado positivo (traços até 3+) é indicativo de tratamento. A utilização do Coulter T890® para contagem total de leucócitos representa um método eficaz quando comparado ao método tradicional.

\section{PAPEL DAS MUTAÇÕES NO GENE HFE NA RESPOSTA AO TRATAMENTO ANTI-VIRAL, NOS DEPÓSITOS DE FERRO NO FÍGADO E NA GRAVIDADE DA LESÃO HEPÁTICA EM PACIENTES COM HEPATITE C CRÔNICA}

\section{Marcos de Vanconcelos Carneiro}

Orientadora: Profa. Dra. Ana de Lourdes C. Martinelli Dissertação de Mestrado apresentada em 12/06/2006

A infecção crônica pelo HCV é um importante problema de saúde pública, e uma das principais causas de hepatopatia crônica. O tratamento anti-viral padrão da hepatite $\mathrm{C}$ crônica consiste na combinação de interferon combinado à ribavirina. Alguns fatores foram identificados como preditores de resposta virológica sustentada como genótipo não 1 e carga viral baixa do HCV, sexo feminino, idade $\leq 40$ anos, e ausência de fibrose hepática avançada. A infecção crô- nica pelo $\mathrm{HCV}$ é frequientemente associada com sobrecarga de ferro no organismo. A relação dos depósitos de ferro no fígado com a presença de mutações no gene HFE é debatida. O papel da mutação no gene HFE nos depósitos de ferro, grau de lesão hepática e resposta ao tratamento anti-viral ainda é controverso. Os objetivos deste estudo foram avaliar, em pacientes com infecção crônica pelo HCV, o papel das mutações no gene HFE (C282Y e H63D) na resposta ao tratamento anti-viral, nos depósitos de ferro no fígado e sua distribuição intra-hepática, e no grau de lesão hepática (fibrose e atividade inflamatória). Foram estudados 264 pacientes com infecção crônica pelo 
HCV tratados com interferon e ribavirina, divididos em dois grupos segundo o tipo de resposta viro lógica: RVS (resposta virológica sustentada) e NR (sem resposta ou recaída). Avaliou-se a relação entre tipo de resposta ao tratamento e parâmetros clínicos, bioquímicos (GGT, AST, ALT, ferro, saturação de transferrina, e ferritina), histológicos (fibrose e atividade inflamatória, depósitos de ferro), virológicos do HCV (genótipo e carga viral) e mutações no gene HFE (H63D e C282Y). Dos 264 pacientes, 88 (32,1\%) apresentaram RVS. A análise bivariada identificou como fatores relacionados a RVS o genótipo do HCV, GGT, ferritina, saturação de transferrina, qualquer mutação no gene HFE e mutação no gene H63D. Na análise multivariada, os fatores identificados associados a RVS foram 2 ou 3 do HCV ( $P<0,0001)$, saturação de transferrina $\leq 45 \%(\mathrm{P}=0,04)$ e a presença de mutação no gene H63D ( $\mathrm{P}=0,02)$. Não houve diferença entre NR e RVS com relação a lesão hepática e detecção de ferro no fígado. Depósitos de ferro hepático foram observados em 49,2\% dos pacientes, sem relação com gravidade da lesão hepática (fibrose e atividade necro-inflamatória), porém a esteatose hepática foi mais frequiente naqueles com siderose hepática do que naqueles sem siderose $(60,2 \%$ vs $46,8 \%$, $\mathrm{P}=0,03)$. A mutação no gene HFE foi mais freqüente nos com siderose do que naqueles sem $(63,4 \%$ vs $42,4 \%, \mathrm{P}=0,004)$, particularmente nos hepatócitos e sinusóides. Pacientes com siderose apresentavam maior freqüência de ferritina acima do LSN (50\% vs $16,6 \%, \mathrm{P}<0,0001)$. Não houve associação entre parâmetros bioquímicos de ferro e mutação no gene HFE. Conclui-se que em pacientes com infecção crônica pelo HCV genótipo 2 ou 3 do $\mathrm{HCV}, \mathrm{ST} \leq 45 \%$ e presença da mutação H63D, foram fatores preditivos de RVS à terapia anti-viral. Depósitos de ferro no fígado foram freqüentes havendo associação desses com a presença de mutação no gene HFE, saturação de transferrina elevada, níveis aumentados de ferritina e esteatose. A presença da mutação no gene HFE não foi associada com maior gravidade da doença hepática.

\section{ESTUDO DOS SINTOMAS DISPÉPTICOS, DE TESTE DE SACIEDADE, DO ESVAZIAMENTO GÁSTRICO DE LÍQUIDO E DA ESPESSURA DA PAREDE GÁS- TRICA EM PACIENTES COM GASTROPATIA HIPERTENSIVA PORTAL}

\section{Lucia Helena Bessa Penhalber}

Prof.Dr. Ulysses Garzella Meneghelli

Dissertação de Mestrado apresentada em 13/06/2006

Este trabalho teve como objetivo identificar a presença e a intensidade de sintomas dispépticos, de realizar um teste destinado à avaliação do sintoma saciedade máxima (slow drink test), de estudar o esvaziamento gástrico de uma refeição líquida com marcador radioativo e de medir, por meio de método ultrasonográfico, a espessura da parede do antro gástrico em pacientes com gastropatia hipertensiva portal (GHP). Procurou-se também relacionar os sintomas apresentados pelos pacientes com os dados funcionais e anatômicos obtidos. Foram incluídos 39 pacientes com cirrose hepática de etiologia alcoólica $(\mathrm{n}=18)$, ou causada pelos vírus da hepatite B ou C $(n=10)$ ou pela associação de álcool e vírus $(\mathrm{n}=11)$, portadores de GHP diagnosticada por meio de exame endoscópico convencional. Quarenta e quatro voluntários saudá- veis, distribuídos nos diferentes testes realizados, serviram como controles. Os resultados, mostrados a seguir, evidenciaram que: 1) $37 \%$ dos pacientes não apresentavam sintomas dispépticos ou tinham-nos de grau leve, em $63 \%$ dos casos os sintomas dispépticos foram considerados de grau moderado ou grave. Os sintomas mais freqüentes foram eructações, plenitude pós-prandial e saciedade precoce. O sintoma dor epigástrica esteve presente em apenas $16 \%$ dos pacientes; 2 ) no teste de saciedade, a quantidade de Kcal ingeridas até alcançar o ponto de saciedade máxima nos pacientes com GHP foi inferior à do grupo controle (mediana; variação: $416 \mathrm{kcal} ; 135-1508 \mathrm{kcal}$ vs $821 \mathrm{kcal}$; 630-1260; $\mathrm{p}=0,002)$; 3) Os pacientes com GHP apresentaram tempo médio $\left(\mathrm{T}_{1 / 2}\right)$ do esvaziamento gástrico aumentado (mediana; variação: $87 \mathrm{~min}$; 60-151 $\mathrm{min}$ vs $62 \mathrm{~min}$; 45-99 $\mathrm{min}$; $\mathrm{p}=0,0001$ ); 4) no teste de esvaziamento gástrico, não houve diferença na distribuição intragástrica da refeição líquida entre os grupos estudados tanto no que se refere aos valo- 
res da atividade proximal inicial (mediana; variação: $59,9 \%$; 45,4-68,7\% vs 59,4\%; 38,3-73,1\%; $\mathrm{p}=0,70)$; quanto aos valores da atividade proximal média (mediana; variação: $54,0 \%$; $39,8-70,1 \%$ vs $57,6 \%$; $38,5-62,6 \%, \mathrm{p}=0,61)$; 5) os pacientes com GHP apresentaram aumento da espessura da parede do antro gástrico (mediana; variação: $19 \mathrm{~mm} ; 10-28 \mathrm{~mm}$ vs $13 \mathrm{~mm}$; $10-17 \mathrm{~mm} ; \mathrm{p}=0,0002)$; 6 ) houve correlação inversa (Rs=-0,45; $\mathrm{p}=0,007)$ entre $\mathrm{o} \mathrm{T}_{1 / 2}$ e o máximo de kcal ingeridas no teste de saciedade, $\mathrm{T}_{1 / 2}$ - mediana; variação: 87 min; 60-151 min vs -62 min; 45-99 min) e (mediana; variação: $416 \mathrm{kcal} ; 135-1508 \mathrm{kcal}$ vs 630 kcal; 630-1260 kcal); 7) houve correlação inversa ( $\mathrm{Rs}=; \mathrm{p}=$ ) entre o teste de saciedade e os valores obtidos na espessura da parede do antro gástrico (mediana; variação: 416 kcal; 135-1508 kcal vs 630 kcal;
630-1260 kcal) e (mediana; variação: $19 \mathrm{~mm} ; 10-28$ $\mathrm{mm}$ vs $13 \mathrm{~mm} ; 10-17 \mathrm{~mm}$ ). Elevada freqüência e o tipo dos sintomas dispépticos predominantes, sugerem que a GHP tem expressão sintomática. O retardo do esvaziamento gástrico, que está associado aos sintomas dispépticos dos pacientes com gastropatia hipertensiva portal, talvez numa associação do tipo causa e efeito, representaria uma característica fisiopatológica desta gastropatia. A presença de saciedade, precocemente atingida nos pacientes com GHP, conforme verificado no teste da saciedade, além de outros sintomas dispépticos, sugere que os pacientes cirróticos com GHP poderiam ter sua ingestão calórica diária limitada, o que poderia levar a um défice de ingestão de alimentos, então contribuindo para a desnutrição do paciente

\section{TRANSPLANTE DE CÉLULAS-TRONCO HEMATOPOÉTICAS PARA DOEN- ÇAS AUTO-IMUNES GRAVES E REFRATÁRIAS AO TRATAMENTO CONVEN- CIONAL}

\section{Maria Carolina de Oliveira Rodrigues \\ Orientador: Prof. Dr. Júlio César Voltarelli \\ Dissertação de Mestrado apresentada em 13/06/2006}

As doenças auto-imunes caracterizam-se por perda de tolerância imunológica aos auto-antígenos e conseqüente agressão aos tecidos. Algumas doenças auto-imunes evoluem de modo agressivo e refratário ao tratamento convencional, com altos índices de morbidade e mortalidade. A imunossupressão em altas doses, seguida por infusão de células-tronco autólogas, vem se estabelecendo em todo o mundo como alternativa terapêutica. $\mathrm{O}$ presente trabalho visa relatar a experiência clínica preliminar do transplante autólogo de células-tronco no Hospital das Clínicas da Faculdade de Medicina de Ribeirão Preto da Universidade de São Paulo. Foram selecionados pacientes portadores de formas graves e refratárias das seguintes doenças: lúpus eritematoso sistêmico, esclerose múltipla, esclerose sistêmica, doenças bolhosas cutâneas e arterite de Takayasu. Na primeira fase do transplante, os pacientes foram submetidos a mobilização e coleta das células progenitoras hematopoéticas. $\mathrm{Na}$ segunda fase, receberam doses imunoablativas de quimioterápicos, seguidas por infusão das células-tronco previamente colhidas e congeladas. Após o trans- plante, os pacientes foram acompanhados periodicamente e foram avaliados aspectos como mortalidade e complicações associadas ao transplante, dificuldades e adaptações do protocolo ao nosso meio e evolução da qualidade de vida. Foram descritos os resultados, com especial atenção para a esclerose múltipla e foi realizada comparação com dados da literatura. Não houve número suficiente de pacientes para análise estatística. Trinta e dois pacientes foram inseridos no estudo e 26 foram submetidos ao transplante. Dezenove pacientes encontravam-se avaliáveis póstransplante e dezoito apresentavam remissão da atividade da doença. Um paciente apresentou progressão de esclerose múltipla 720 dias pós-transplante. Houve nove óbitos relacionados ao transplante, por complicações principalmente infecciosas. Conclui-se que o transplante autólogo é viável como alternativa terapêutica para doenças auto-imunes graves e refratárias em nosso meio, porém a mortalidade observada foi excessiva. Foram realizadas alterações no protocolo de transplante para esclerose múltipla com redução da mortalidade e da incidência de intercorrências. Outras mudanças serão necessárias também nos transplantes para lúpus eritematoso sistêmico e esclerose sistêmica, visando aumentar a segurança do procedimento. 


\section{FARMACOLOGIA}

\section{INTER-RELAÇÃO E MECANISMOS ENVOLVIDOS NA HIPERNOCICEPÇÃO MECÂNICA E MIGRAÇÃO DE NEUTRÓFILOS INDUZIDOS PELA IL-15}

\author{
Waldiceu Aparecido Verri Junior \\ Orientador: Prof. Dr. Sérgio Henrique Ferreira \\ Tese de Doutorado apresentada em 20/04/2006
}

A IL-15 participa da indução e manutenção de doenças inflamatórias. Corroborando, terapias direcionadas a IL-15 são efetivas no tratamento de artrite reumatóide experimental e clínica. Considerando que hiperalgesia e migração de neutrófilos acompanham a artrite reumatóide, foi investigada a habilidade da IL-15 em induzir esses efeitos, sua inter-relação e participação da IL-15 em modelo de resposta inflamatória de origem imune em camundongos. A injeção intraplantar (i.pl.) de IL-15 induziu hipernocicepção (sensibilização dos nociceptores) mecânica dose- e tempo-dependente. A hipernocicepção mecânica induzida pela IL-15 foi inibida pelo tratamento com um antagonista misto $\mathrm{ET}_{\mathrm{A}} / \mathrm{ET}_{\mathrm{B}}$ de receptores para endotelina (bosentan), antagonista de receptores $\mathrm{ET}_{\mathrm{A}}$ (BQ-123) ou inibidor da ciclooxigenase (indometacina). Ademais, a hipernocicepção induzida pela IL-15 foi reduzida em camundongos deficientes (-/-) para IFN- $\gamma$. Esses resultados sugerem que a indução hipernociceptiva pela IL-15 é mediada pelo IFN- $\gamma$, endotelinas e prostanóides. Corroborando, a injeção i.pl. de IFN- $\gamma$ ou ET-1 induziram hipernocicepção mecânica dose- e tempodependente, inibidas pelo tratamento com BQ-123 ou indometacina. Além disso, o IFN- $\gamma$ induziu aumento da produção de ET-1 e expressão de RNAm para o seu precursor (prepro-ET-1, PPET-1). A IL-15 também induziu aumento da produção de ET-1 e expressão de RNAm para PPET-1 de maneira dependente de IFN$\gamma$, bem como a produção de IFN- $\gamma$ no tecido plantar. A IL-15, IFN- $\gamma$ e ET-1 induziram a produção de PGE $_{2}$ no tecido plantar. Também foi detectada a participação da IL-15, IFN- $\gamma$, endotelinas e prostanóides na hipernocicepção mecânica induzida pelo desafio i.pl. com ovalbumina (OVA) em animais imunizados como demonstrado pelo tratamento dos camundongos com sIL$15 \mathrm{R} \alpha$ (receptor solúvel para IL-15), animais IFN- $\gamma-/-$, bosentan, BQ-123 ou indometacina, respectivamente. Ratificando esses dados comportamentais, o desafio i.pl. com OVA em animais imunizados induziu o aumento da expressão de RNAm para PPET-1, o qual foi inibido pela deleção gênica do IFN- $\gamma$ ou pelo tratamento com sIL-15R $\alpha$. Nesse modelo, a produção de IFN- $\gamma$ também foi inibida pelo tratamento com sIL$15 \mathrm{R} \alpha$ e em animais IL-18-/-. Assim, esses resultados sugerem que durante a hipernocicepção inflamatória imune iniciada por um antígeno inicia-se uma cascata de mediadores: IL-15 $\rightarrow$ IFN $\gamma \rightarrow$ ET- $1 \rightarrow$ PGE $_{2}$. Ademais, utilizando abordagens farmacológicas semelhantes foi demonstrado que a IL-18 induziu hipernocicepção em camundongos pelo mesmo mecanismo que a IL-15 (IFN $\gamma \rightarrow$ ET-1 $\rightarrow$ PGE $_{2}$ ), participando do mesmo modelo de inflamação. Além disso, a hipernocicepção induzida pela IL-15 foi dependente, pelo menos em parte, da migração de neutrófilos induzida pela mesma ao tecido subcutâneo plantar. Essa hipótese baseia-se no fato de ambos os efeitos induzidos pela IL-15 foram inibidos pelo tratamento com fucoidina (inibidor da migração de neutrófilos) e deleção da molécula de adesão, ICAM-1. Por outro lado, a IL-15 induziu migração de neutrófilos dose- e tempo-dependente para a cavidade peritoneal, inibida pelo tratamento com anticorpo anti-MIP-2/CXCL2 e MK886 (inibidor da síntese de leucotrienos) e pela deleção gênica da IL-18, MIP-1 $\alpha /$ CCL3, TNF- $\alpha$ e 5-lipoxigenase. Não há participação significativa de endotelinas na migração de neutrófilos induzida pela IL-15. Ainda, a injeção intraperitoneal de IL-15 induziu a liberação de IL-18, MIP-2/CXCL2, MIP-1 $\alpha /$ CCL3, TNF- $\alpha$ e LTB $_{4}$. O tratamento com sIL-15R $\alpha$ ou deleção gênica da IL-18 inibiram a migração de neutrófilos induzida pelo desafio intraperitoneal com OVA em animais imunizados e a liberação de MIP-2/ CXCL2, MIP-1 $\alpha /$ CCL3, TNF- $\alpha$ e LTB ${ }_{4}$. Assim, em conjunto com outros dados do laboratório, os resultados sugerem que o desafio com antígeno induz migração de neutrófilos pela liberação de uma cascata de mediadores com participação preponderante da 
IL-15 (Antígeno à IL-15 $\rightarrow$ IL-18 $\rightarrow$ MIP-2/CXCL2 $\rightarrow$ MIP- $1 \alpha /$ CCL3 $\rightarrow$ TNF- $\alpha \rightarrow$ LTB $_{4} \rightarrow$ Migração de neutrófilos). Dessa forma, os resultados são compatíveis com a hipótese de que a IL-15 participa na hipernocicepção e migração de neutrófilos induzidos por estímulo inflamatório de padrão Th1. Além disso, a IL-15 induziria hipernocicepção mecânica e migração de neutrófilos por mecanismos diferentes. Contudo, parece que o infiltrado neutrofílico participa na hipernocicepção, provavelmente, produzindo mediadores como IFN- $\gamma$, ET-1 e/ou PGE 2 . Por outro lado, a contribuição dos neutrófilos parece ser parcial, visto que, abolindo a sua presença, a hipernocicepção é apenas reduzida. Mecanismos específicos para cada tipo de tecido também podem ser uma explicação. Concluindo, este trabalho contribuiu para elucidação, pelo menos parte, dos mecanismos ativados pela IL-15 para induzir hipernocicepção mecânica e migração de neutrófilos, a participação da IL-15 em resposta inflamatória de origem imune e da relação entre migração de neutrófilos e indução da hipernocicepção pela IL-15. Ao fazê-lo, também foram sugeridas diferentes abordagens para controlar a atividade da IL-15 durante um processo inflamatório de origem imune.

\section{PAPEL DA VIA HEME OXIGENASE / MONÓXIDO DE CARBONO-BILIVERDINA/ GMPc NA MODULAÇÃO DO RECRUTAMENTO DE NEUTRÓFILOS NA VIGÊN- CIA DO PROCESSO INFLAMATÓRIO}

\section{Andressa de Freitas}

Orientador: Prof. Dr. Fernando de Queiróz Cunha

Dissertação de Mestrado apresentada em 25/04/2006

A migração de neutrófilos durante o processo inflamatório é mediada por vários fatores quimiotáticos, como citocinas e quimiocinas. Concomitante à liberação dos mediadores pró-inflamatórios há também a liberação de mediadores antiinflamatórios, como lipoxina, IL-4, IL-10, óxido nítrico (NO). Recentemente, foi demonstrado que a enzima heme oxigenase (HO) modula a resposta inflamatória. Assim, o objetivo do presente trabalho foi investigar o papel da via heme/ HO/ monóxido de carbono (CO)-biliverdina no recrutamento de neutrófilos durante o processo inflamatório agudo. Nossos resultados demonstram que, a inibição da $\mathrm{HO}$ com zinco deuteroporfirina 2, 4 bis glicol (ZnDPBG), inibidor inespecífico da HO, promove potencialização da migração de neutrófilos, rolamento e adesão dos leucócitos ao endotélio induzidos pela administração de baixa dose de carragenina $(\mathrm{Cg})$, bem como na migração de neutrófilos estimulada pela administração de lipopolissacarídeo (LPS). Além disso, demonstramos que a administração de $\mathrm{Cg}$ promove aumento da atividade da $\mathrm{HO}$, avaliada através do aumento dos níveis de bilirrubina no lavado peritoneal, a qual foi inibida pelo pré-tratamento dos animais com o inibidor inespecífico da HO (ZnDPBG). Posteriormente, verificamos que a administração do substrato da HO (hemin), da biliverdina e dos doado- res de $\mathrm{CO}$ : dimanganes decacarbonil (DMDC), ferro tetracarbonila diiodeto $\left(\mathrm{Fe}(\mathrm{CO})_{4} \mathrm{I}_{2}\right)$ e molibdênio tetracarbonila diiodeto $\left(\mathrm{Mo}(\mathrm{CO})_{4} \mathrm{I}_{2}\right)$ promovem redução na migração dos neutrófilos induzida pela administração de Cg ou LPS e, no rolamento e adesão dos leucócitos induzidos pela administração de Cg. Sugerindo que, durante o processo inflamatório agudo, a $\mathrm{HO}$ atua modulando negativamente a interação leucócito- endotélio e, conseqüentemente o recrutamento de neutrófilos, através da formação de $\mathrm{CO}$ e biliverdina. Observamos também que, a redução no recrutamento de neutrófilos promovida pelos produtos da HO não se deve a uma redução na síntese e/ou liberação de fator de necrose tumoral- $\alpha$ (TNF- $\alpha$ ) ou interleucina $-1 \beta$ (IL-1 $\beta$ ), na vigência do processo inflamatório induzido por $\mathrm{Cg}$. Além disso, verificamos que o efeito inibitório do DMDC (doador de CO) sobre o recrutamento de neutrófilos, mas não o efeito inibitório da biliverdina, foi abolido quando os animais foram pré-tratados com o inibidor da guanilato ciclase solúvel (GCs), ODQ, indicando que o CO atua inibindo o recrutamento de neutrófilos via ativação da GCs. Adicionalmente, foi observado que a inibição da óxido nitrico sintase (NOS) não foi capaz de reverter a redução da migração de neutrófilos promovida pelo prétratamento dos animais com DMDC ou biliverdina, sugerindo que o NO não está envolvido com a redução da migração de neutrófilos promovida pelos produtos da HO. No entanto, o pré-tratamento dos camundongos com $\mathrm{ZnDPBG}$, inibidor da $\mathrm{HO}$, bloqueia a 
capacidade do SNAP, doador de NO, em reduzir a migração de neutrófilos, induzida pela $\mathrm{Cg}$, indicando que a $\mathrm{HO}$ está envolvida na redução da migração de neutrófilos exercida pelo NO. Por fim, constatamos que a administração de $\mathrm{Cg}$ induz a expressão da HO-1 nas células endoteliais venulares e que, o prétratamento dos animais com zinco protoporfirina IX (ZnPP IX), inibidor específico da HO-1, promove potencialização do recrutamento de neutrófilos, durante o processo inflamatório. Desta forma, nossos resultados demonstram que, durante o processo inflamatório agudo ocorre aumento na expressão e da atividade da $\mathrm{HO}$ com conseqüente formação de $\mathrm{CO}$ e biliverdina, os quais modulam negativamente o recrutamento de neutrófilos para a cavidade peritoneal, por mecanismos dependentes e independentes da ativação da GCs, respectivamente. Entretanto, essa diminuição do recrutamento de neutrófilos não se deve a uma redução da síntese e/ou liberação de TNF- $\alpha$ ou IL- $1 \beta$. Ademais, os produtos da $\mathrm{HO}$ medeiam o efeito inibitório do NO sobre a migração dos neutrófilos ao sítio inflamatório.

\section{RELEVÂNCIA CLÍNICA DE HAPLÓTIPOS DA SINTASE ENDOTELIAL DO ÓXI- DO NÍTRICO PARA A SUSCEPTIBILIDADE À HIPERTENSÃO ARTERIAL E RES- POSTA AO TRATAMENTO ANTI-HIPERTENSIVO}

\section{Valeria Cristina Sandrim}

Orientador: Prof. Dr. José Eduardo Tanus dos Santos

Tese de Doutorado apresentada em 25/04/2006

No presente estudo, nós comparamos a distribuição das freqüências genotípicas e alélicas destes três polimorfismos entre hipertensos (112 brancos e 91 negros) e normotensos (113 brancos e 87 negros). Além disso, nós examinamos a associação de haplótipos da eNOS e hipertensão em brancos e negros. Nossos resultados indicam ausência de associação entre genótipos da eNOS e hipertensão em ambos grupos étnicos ( $\mathrm{P}>0,05)$. Entretanto, os haplótipos "T-Aspb" e "C Glu b" (protetor) foram mais freqüentes em normotensos brancos (16 e $24 \%$, respectivamente) e negros (17 e $16 \%$, respectivamente) do que em bran$\cos (7$ e $8 \%$, respectivamente) e negros (4 e $6 \%$, respectivamente) hipertensos. Além disso, o haplótipo " $\mathrm{C}$ Asp b" (susceptível) foi mais comum em brancos hipertensos do que em brancos normotensos $(\mathrm{P}=0,0007)$.

De grande relevância clínica, os mesmos haplótipos da eNOS, mas não os genótipos, foram associados a um efeito protetor (C Glu b) e susceptível (C Asp b) no desenvolvimento da hipertensão em diabéticos tipo 2 (DMT2), sugerindo a contribuição de haplótipos no desenvolvimento da hipertensão é mascarada quando genótipos da eNOS são considerados individualmente. Soma-se a isto, que nossos resultados indicam que haplótipos da eNOS estão associados com um efeito protetor contra o desenvolvimento da hipertensão em ambos grupos étnicos e em DMT2 e outro haplótipo confere susceptibilidade à hipertensão em indivíduos brancos e em DMT2.

A maioria dos pacientes hipertensos requer 2 ou mais drogas para o controle efetivo da pressão sanguínea. Enquanto, nossos resultados indicam associação entre haplótipos da eNOS e hipertensão, ainda se desconhece se genótipos/haplótipos da eNOS estão associadas com resistência à terapia anti-hipertensiva. Desta maneira, nestes estudos nós comparamos a distribuição dos polimorfismos T- ${ }^{786} \mathrm{C}$, Glu298Asp e 4a4b in 111 em normotensos (NT), 116 hipertensos com pressões sanguíneas bem controladas, e 100 hipertensos resistentes à terapia anti-hipertensiva (HTR). Comparamos também a distribuição de haplótipos da eNOS nestes três grupos de indivíduos. Enquanto nenhuma diferença significativa foi encontrada na distribuição genotípica destes variantes entre os três grupos, diferenças significativas foram observadas, sendo que o haplótipo "C Glu b" foi mais comum no grupo NT comparado aos grupos HT e HTR (21\% versus $8 \%$ e $7 \%$, respectivamente; ambos $\mathrm{P}<0,00625$ ), e o haplótipo " $\mathrm{C}$ Asp b" mais freqüente nos grupos HT e HTR comparados ao grupo NT $(22 \%$ e $20 \%$, respectivamente, versus $8 \%$; ambos $\mathrm{P}<0,00625$ ). Finalmente, a distribuição dos haplótipos da eNOS não foi significativamente diferentes entre os grupos HT e HTR $(\mathrm{P}>0,05)$. Portanto, nossos achados sugerem novamente um efeito protetor e susceptível dos haplótipos "C Glu b" e "C Asp b", respectivamente no desenvolvimento da hipertensão arterial. Além disso, nossos resultados sugerem que os haplótipos da eNOS não estão associa- 
dos à resistência à terapia anti-hipertensiva.

Finalmente, neste estudo nós avaliamos a associação entre haplótipos/genótipos da eNOS (T-786C, Glu298Asp e intron 4) com níveis plasmáticos de nitrato/nitrito (NOx), que são produtos estáveis do NO, em 98 indivíduos sadios, 68 pacientes HT, 66 pacientes DMT2, e 86 pacientes DMT2+HT. Pôde-se observar que não houve diferenças na distribuição de genótipos da eNOS entre os grupos estudados. Além disso, nossos resultados indicam ausência de associação entre os níveis de NOx e genótipos da eNOS nos quatro grupos de indivíduos. Com relação aos haplótipos da eNOS, a combinação haplotípica "C Glu b" foi mais freqüente no grupo de saudáveis do que nos grupos HT e DMT2+HT. Este mesmo haplótipo foi mais co- mum entre os indivíduos dos grupos HT e DMT2+HT com altas concentrações de NOx comparado aos indivíduos com baixas concentrações de NOx. Já o haplótipo "C Asp b" foi mais freqüente nos grupos HT e DMT2+HT. Este mesmo haplótipo também foi mais comum nos grupos HT e DMT2+HT apresentando baixos níveis de NOx do que no grupo com altas concentrações de NOx. Estes resultados fundamentam os resultados encontrados nos estudos de associação, pois indicam que o haplótipo "C Glu b" que protege contra o desenvolvimento de hipertensão está associado com altos níveis de NOx, enquanto que o haplótipo "C Asp b", associado a maior susceptibilidade ao desenvolvimento da hipertensão está associado a níveis menores destas espécies relacionadas ao NO.

\section{RESPOSTA FEBRIL INDUZIDA PELA INJEÇÃO DE STAPHYLOCCOCUS AUREUS: EFEITO DE DROGAS COM ATIVIDADE ANTIPIRÉTICA}

\section{Daniela Tagliari Longhi}

Orientadora: Profa.Dra. Glória Emília Petto de Souza

Dissertação de Mestrado apresentada em 20/06/06

Até o presente momento, estudos demonstraram que a parede celular de $S$. aureus induz febre em ratos e cabras, e que toxinas produzidas pelo $S$. $a u$ reus, como por exemplo, as enterotoxinas SEA e SEB (staphylococcal enterotoxins A e B) induzem febre em gatos e coelhos. Entretanto, nenhum estudo empregou a bactéria viva no modelo de febre. No presente estudo foi padronizado o modelo de resposta febril induzido pela injeção i.p. de Staphylococcus aureus (ATCC 25923) em ratos e posteriormente, avaliado o efeito de drogas que apresentam atividade antipirética sobre a febre induzida por esta bactéria. Verificou-se que a injeção i.p. de $S$. aureus induz aumento, duradouro e dose-dependente da temperatura corporal em ratos. Além disso, o aumento da temperatura corporal induzido por esta bactéria trata-se de febre e não hipertermia, pois foi acompanhado de redução da temperatura da pele da cauda dos animais, indicativo de vasoconstrição periférica também observado pela redução do índice de perda de calor (IPC). Demonstrou-se também, que o aumento de temperatura observado acompanha a presença de bactérias viáveis no foco infeccioso e sangue. Estudos têm apontado a enzima COX-2 como a principal isoforma de COX, responsável pela síntese de prostaglandinas durante a febre. No presente estudo, verificou-se que o celecoxibe, um inibidor seletivo para a COX-2, promoveu redução significativa e de maneira dose-dependente da resposta febril induzida pelo $S$. aureus. Além disso, o celecoxibe reverteu a vasoconstrição periférica induzida por esta bactéria. O pré-tratamento com paracetamol e dipirona reduziu significativamente a febre induzida pelo $S$. aureus sugerindo a participação de outros mediadores. Observou-se também que a administração de dexametasona, um antiflamatório esteroidal, reduziu significativamente a temperatura corporal dos animais injetados com $S$. aureus, indicando que a resposta febril induzida por este estímulo depende de neo-síntese de mediadores pirogênicos. A fim de averiguar a participação de endotelinas neste modelo, avaliou-se o efeito de antagonistas de receptores para endotelinas. Verificou-se que tanto o BQ-123, antagonista seletivo de receptor $\mathrm{ET}_{\mathrm{A}}$, quanto o $\mathrm{BQ}-788$, antagonista seletivo de receptor $\mathrm{ET}_{\mathrm{B}}$, reduziram significativamente a febre induzida pelo $S$. aureus. A IL-1 parece não estar envolvida nesta resposta, pois a injeção i.c.v. de antagonista de receptores da IL-1 (IL-1ra) não alterou a febre promovida pelo $S$. aureus. Em síntese, esses resultados sugerem que a febre induzida pela injeção i.p. de $S$. aureus depende de PGs, sintetizadas via COX-2, de endotelinas e independe da produção central de IL-1. 


\section{PARTICIPAÇÃO DAS QUIMIOCINAS CXCL1 (KC) E CXCL5 (LIX) E DO LTB NA MIGRAÇÃO DE NEUTRÓFILOS PARA A CAVIDADE ARTICULAR EM MODELO DE ARTRITE INDUZIDA POR mBSA}

\section{Renata Grespan}

Orientador:Prof. Dr. Fernando de Queiróz Cunha

Dissertação de Mestrado apresentada em 20/06/2006

Os neutrófilos estão envolvidos na resposta inflamatória aguda, e contribuem para a inflamação e destruição da articulação características da artrite reumatóide. Neste estudo, avaliamos a participação de diversos mediadores inflamatórios envolvidos no recrutamento de neutrófilos para a cavidade articular no modelo de artrite induzida por albumina bovina sérica metilada (mBSA) e o mecanismo pelo qual este recrutamento ocorre. Nós encontramos que a administração intra-articular de mBSA em animais imunizados, porém, não em animais controles, induziu um acúmulo de neutrófilos na cavidade articular de maneira dose e tempo dependentes, o qual era inibido por repertaxina (antagonista dos receptores CXCR1 e
CXCR2), por anticorpos anti-CXCL1 e anti-CXCL5, e por MK 886 (inibidor da síntese de leucotrienos), porém, não por BN 50730 (antagonista do receptor de PAF). Confirmando a participação destes mediadores, observamos que as concentrações de CXCL1, CXCL5 e leucotrieno $\mathrm{B}_{4}\left(\mathrm{LTB}_{4}\right)$ estavam elevadas no exsudato articular dos animais imunizados e desafiados com mBSA e ainda, a administração intra-articular destes mediadores quimiotáxicos induziu uma elevada migração de neutrófilos. Além disso, a repertaxina inibiu a produção de $\mathrm{LTB}_{4}$ no exsudato articular e o MK 886 reduziu a migração de neutrófilos para a cavidade articular induzida por CXCL1 e por CXCL5. Em resumo, as quimiocinas CXC (CXCL1 e CXCL5) e $\mathrm{LTB}_{4}$ atuando seqüencialmente estão envolvidos na migração de neutrófilos no modelo de artrite induzida por mBSA. Desta maneira, a inibição das quimiocinas CXCL1 e CXCL5 e de $\mathrm{LTB}_{4}$ são sugeridos como novas terapias para a artrite reumatóide.

\section{PAPEL DO PEROXINITRITO NA MIGRAÇÃO DE NEUTRÓFILOS PARA O FOCO INFECCIOSO E NA DISFUNÇÃO CARDIOVASCULAR DURANTE A SÉPSIS GRAVE}

\section{Diego Torres Dueñas}

Orientador: Prof.Dr. Fernando de Queiroz Cunha

Tese de Doutorado apresentada em 21/06/2006

A falência de migração de neutrófilos (FMN), caracterizada pela deterioração do rolamento, adesão e da migração dos neutrófilos para o foco infeccioso representa um elemento chave no cenário da sépsis. O óxido nítrico derivado da sintase induzível do óxido nítrico (iNOS) parece ser o maior mediador desses eventos, uma vez que a inibição farmacológica ou genética (-I-) da iNOS atenua a FMN.

No presente estudo demonstramos que o peroxinitrito está envolvido no efeito inibitório do NO sobre a migração de neutrófilos na sépsis grave. $\mathrm{O}$ tratamento com ácido úrico (inibidor do peroxinitrito) dos animais submetidos a sépsis polimicrobiana grave in- duzida por CLP melhora significativamente a migração de neutrófilos para o foco infeccioso. Conseqüentemente, diminuiu a contagem de bactérias no exsudato peritoneal e no sangue, reduziu a resposta inflamatória sistêmica determinada pelos níveis de citocinas circulantes e o grau de infiltração de neutrófilos no tecido pulmonar e aumentou a taxa de sobrevida dos animais. Ademais, foi observado um incremento na marcação para 3-nitrotirosina (indicador morfológico da nitração dos resíduos de tirosina pelo peroxinitrito) no mesentério e nos leucócitos da cavidade peritoneal, a qual foi significativamente diminuída com o tratamento com ácido úrico. Assim, a inibição do peroxinitrito pode constituir um novo alvo terapêutico no controle do processo séptico.

O presente trabalho também demonstra pela primeira vez que, o peroxinitrito produzido durante $\mathrm{o}$ choque séptico (induzido por CLP) é responsável pelo 
colapso cardiovascular. É bem sabido que, inúmeros mediadores como citocinas, prostaglandinas, bradicinina bem como o NO aparecem envolvidos na disfunção cardiovascular presente na sépsis grave. Contudo, na última década o peroxinitrito produzido pela reação entre o NO e o radical superoxido tem sido indicado como o responsável de alguns efeitos que eram atribuídos ao NO.

No cenário da sépsis ou da endotoxemia, tem sido observado que o peroxinitrito é produzido durante a fase inicial da endotoxemia experimental e em pacientes sépticos. O qual aparece como responsável da diminuição da reatividade vascular aos agentes vasoconstritores durante o choque endotóxico. De fato, em nosso modelo foi observado também, que o pré-tratamento dos animais submetidos à lesão séptica grave com ácido úrico, AU (inibidor do peroxinitrito) preveniu de forma significativa a hipotensão grave, melhora a resposta pressora, in vivo, à fenilefrina (agonista alfa 1 adrenérgico seletivo), diminuiu significativamente a marcação, no coração, de 3-nitrotirosina diretamente relacionada com a disfunção miocárdica dos animais em choque séptico polimicrobiano.
Observou-se também uma hiper reatividade contrátil cardíaca, basal bem como em resposta à isoprenalina durante a fase inicial do choque séptico polimicrobiano a qual foi revertida pela inibição do peroxinitrito com AU. Encontramos significativas alterações estruturais cardíacas (Incremento no diâmetro dos cardiomiócitos e lesões miocitolíticas focais, múltiplas e difusas do miocárdio) nos animais submetidos ao choque séptico polimicrobiano. A inibição do peroxinitrito reverteu significativamente o incremento do diâmetro dos cardiomiócitos dos animais submetidos ao choque séptico polimicrobiano.

Em conclusão, nossos resultados demonstram uma correlação direta entre a produção incrementada do peroxinitrito durante o choque séptico com a alteração da interação leucócito-endotélio, a falência de migração dos neutrófilos e as alterações da estrutura e função miocárdica com deterioração do perfil hemodinâmico. Ainda, a inibição do peroxinitrito durante o choque séptico polimicrobiano preserva a atividade contrátil e estrutura miocárdica evitando a profunda depressão cardiovascular durante o choque séptico polimicrobiano.

\section{INFLUÊNCIA DE HAPLÓTIPOS DA SINTASE ENDOTELIAL DO ÓXIDO NÍTRI- CO (NO) SOBRE A BIODISPONIBILIDADE SISTÊMICA DE NO}

\section{Ingrid Ferreira Metzger}

Orientador: Prof. Dr. José Eduardo Tanus dos Santos Dissertação de Mestrado apresentada em 21/06/2006

Associações entre polimorfismos no gene da eNOS e as concentrações plasmáticas de nitratos e nitritos (NOx) ainda apresentam controversias. No presente trabalho comparamos a distribuição dos haplótipos envolvendo três polimorfismos relevantes do gene da eNOS $\left(\mathrm{T}-{ }^{786} \mathrm{C}\right.$ na região promotora; $4 \mathrm{~b} / 4 \mathrm{a}$ Intron 4 e Glu298Asp no Exon 7) em indivíduos saudáveis com concentrações plasmáticos de NOx altos e baixos. Estudamos um grupo homogêneo de 154 voluntários (homens, brancos, em jejum, não fumantes, com idade entre 18-60 anos de idade, e que não faziam uso de qualquer medicamento). O DNA genômico foi extraído das amostras de sangue total, a genotipagem foi realizada por PCR seguido de digestão com enzima de restrição. O NOx circulante foi determinado pela técnica de quimioluminescência. As frequiências haplotípicas foram comparadas entre dois grupos de voluntários: os 30 indivíduos com baixas concentrações plasmáticas de NOx (grupo L) e os 30 indivíduos com altos concentrações de NOx plasmático (Grupo H). Os concentrações de NOx nos grupos $\mathrm{L}$ e $\mathrm{H}$ foram de $24,2 \pm 4,5 \mu \mathrm{M}$ e $80,9 \pm 8,9 \mu \mathrm{M}$, respectivamente. As freqüências genotípicas para os três polimorfismos não apresentaram diferenças significativas comparando-se os grupos (todos com $\mathrm{P}>0,05$, no teste $\chi 2$ ). Entretanto, o haplótipo incluindo o alelo " $\mathrm{C}$ " (promotor), 4b (intron 4) e Glu (Exon 7) mostrou-se significativamente mais comum no grupo L (16\%) do que no grupo $\mathrm{H}(4 \%)(\mathrm{P}=0,0047)$. As freqüências dos demais haplótipos não apresentaram diferenças entre os grupos. Enquanto que, ao avaliar a existência de associação entre genótipos da eNOS com NOx circulante, não encontramos diferenças entre os grupos L e H, o haplótipo específico incluindo os alelos "C", "4b" e "Glu" apresentou associação com baixas concentrações de NOx circulante. 


\section{EFEITO CARDIOVASCULAR DA MICROINJEÇÃO DE L-GLUTAMATO NO NÚ- CLEO SUPRA-ÓPTICO DE RATOS NÃO ANESTESIADOS}

\section{Cristiane Busnardo}

Orientador: Prof.Dr. Fernando M. de Aguiar Corrêa Dissertação de Mestrado apresentada em 27/06/2006

O núcleo supra-óptico do hipotálamo (NSO) contém neurônios magnocelulares que sintetizam e secretam vasopressina e ocitocina. A estimulação elétrica do NSO causa resposta pressora através da liberação de vasopressina. O L-glutamato (L-glu) é o principal neurotransmissor excitatório do Sistema Nervoso Central, estando presente no NSO. No presente trabalho relatamos os efeitos cardiovasculares da microinjeção de L-glu no NSO e identificamos os possíveis receptores e mecanismos envolvidos na gênese destes efeitos. Drogas foram microinjetadas em um volume de $100 \mathrm{~nL}$. A microinjeção de L-glu no NSO causou resposta pressora e bradicárdica em ratos nãoanestesiados. As respostas cardiovasculares foram concentração-dependente, apresentando $\mathrm{CE}_{50}$ de aproximadamente $0,1 \mathrm{M}$. As respostas cardiovasculares à injeção de L-glu no NSO foram significativamente reduzidas em ratos anestesiados com uretana. Em ani- mais não anestesiados, a resposta pressora e bradicárdica foi bloqueada pelo pré-tratamento local com NBQX $(0.02 \mathrm{M})$, um antagonista seletivo dos receptores não-NMDA, não sendo afetadas pelo pré-tratamento local com LY $(0.02 \mathrm{M})$, antagonista seletivo de receptores NMDA. Estes resultados sugerem que receptores glutamatérgicos do subtipo não-NMDA medeiam estas respostas. A resposta pressora ao L-glu foi potencializada pela injeção i.v. de pentolínio, bloqueador ganglionar, enquanto a resposta de bradicardia foi bloqueada. A resposta pressora e bradicárdica foi bloqueada pelo pré-tratamento i.v. com dTir $\left(\mathrm{CH}_{2}\right)_{5}(\mathrm{Me}) \mathrm{AVP}$, um antagonista vasopressinérgico. Os resultados sugerem ser a bradicardia de origem reflexa, bem como sugerem o envolvimento de vasopressina na gênese da resposta pressora ao L-glu no NSO.

Em conclusão, os resultados indicam que a resposta pressora à microinjeção de L-glu no NSO é dependente da ativação de receptores glutamatérgicos do subtipo não-NMDA, sendo mediada por liberação de vasopressina para a circulação periférica.

\section{FISIOLOGIA}

\section{INTERAÇÃO DO ÓXIDO NÍTRICO, SEROTONINA E CATECOLAMINAS NA ÁREA PREÓPTICA MEDIAL PARA CONTROLE DA SECREÇÃO DE HORMÔNIO LUTEINIZANTE}

\section{Fernanda Barbosa Lima}

Orientador: Prof. Dr. Celso Rodrigues Franci

Tese de Doutorado apresentada em 11/04/2006

Os neurônios produtores de hormônio liberador de gonadotrofinas $(\mathrm{GnRH})$, presentes principalmente na área preóptica medial (MPOA), constituem a via final comum para controle neural do pico de hormônio luteinizante (LH) no proestro. Entre os neuromediadores envolvidos nesse controle estão a serotonina (5-HT), a noradrenalina (NA), a dopamina (DA), o óxido nítrico (NO) e o neuropeptídeo Y (NPY). Os objetivos deste trabalho foram estudar a interação na MPOA: 1) de 5-HT, NA e DA, e o NO no controle da secreção de LH no proestro; 2) dos sistemas serotoninérgico e NPYérgico no pico de LH induzido por estrógeno $\left(\mathrm{E}_{2}\right)$ e progesterona $\left(\mathrm{P}_{4}\right)$. Ratas Wistar $(250$ $300 \mathrm{~g}$ ) após 3 ciclos regulares foram divididas em dois grupos: I) decapitadas nas diferentes fases do ciclo estral, 30 minutos após injeção i.p. de pargilina, um inibidor da monoaminaoxidase, para verificar o conteúdo de 5-HT, NA e DA na MPOA por meio de cromatografia líquida de alta performance (HPLC) e a atividade e conteúdo de sintase de NO (NOS) por dosagem de citrulina e western blotting, respectivamente; II) ovariectomizadas (OVX) com ou sem reposição hormonal submetidas à microinjeção de 5,7 
dihidroxitriptamina-5,7 DHT, droga que depleta 5-HT, na MPOA e decapitadas para verificar o conteúdo de NPY na MPOA por enzima-imunoensaio (EIA). A concentração plasmática de LH em ambos os grupos foi avaliada por radioimunoensaio. O conteúdo de 5HT, NA e DA não variou na MPOA durante o ciclo estral, mas a atividade serotoninérgica aumentou do metaestro até a tarde do proestro, e diminuiu significativamente na manhã do estro. As atividades de NA e DA aumentaram em todas as fases do ciclo estral, mas sem variação significativa entre elas. A pargilina aumentou a atividade da NOS na MPOA às $9 \mathrm{~h}$ e diminuiu às $11 \mathrm{~h}$, além de diminuir significativamente $o$ conteúdo de NOS na MPOA às $15 \mathrm{~h}$. A pargilina tam- bém bloqueou o pico de LH na tarde de proestro. A depleção de 5-HT na MPOA não alterou o conteúdo de NPY independente de tratamento com esteróides gonadais, mas aumentou a concentração plasmática de LH nas ratas tratadas com $\mathrm{E}_{2}$ e $\mathrm{P}_{4}$. Em conclusão, os resultados do presente trabalho indicam que a 5HT, mas não a NA ou a DA, pode participar dos mecanismos que limitam o pico da secreção de LH e esse efeito inibitório pode ser mediado em parte pelo NO; a MPOA parece ser um dos sítios de ação inibitória da 5-HT sobre a secreção de LH por um mecanismo dependente de $\mathrm{E}_{2}$ e $\mathrm{P}_{4}$; a 5-HT e o NPY na MPOA parecem agir por vias neurais paralelas no controle da secreção de LH.

\section{EFEITOS DA ADMINISTRAÇÃO AGUDA DA AMIODARONA SOBRE A DISTRI- BUIÇÃO REGIONAL DE FLUXO SANGÜÍNEO EM RATOS ANESTESIADOS OU ACORDADOS}

\section{Fernanda Luciano Rodrigues}

Orientador: Prof. Dr. Rubens Fazan Junior

Dissertação de Mestrado apresentada em 12/04/2006

A amiodarona é um agente antiarrítmico comumente utilizado para o tratamento de arritmias ventriculares e supraventriculares. Entretanto, os efeitos hemodinâmicos da amiodarona são relativamente pouco estudados.

O objetivo do presente estudo foi avaliar os efeitos da administração aguda de amiodarona sobre a pressão arterial (PA), freqüência cardíaca (FC), resistência vascular do trem posterior e do leito mesentérico em ratos anestesiados ou acordados.

Ratos Wistar, anestesiados com tiopental sódico $(50 \mathrm{mg} / \mathrm{kg}$ ) foram submetidos a laparotomia mediana para implante de sondas de fluxômetro Doppler ao redor da aorta abdominal (imediatamente acima das artérias ilíacas) ou da artéria mesentérica superior. Ainda, artéria e veia femoral foram canuladas para, registro PA e administração de drogas, respectivamente.

Nos ratos anestesiados, após registro basal da PA e fluxo sanguíneo mesentérico ou do trem posterior, amiodarona (50 mg/kg, i.v.) ou veículo foram administrados, e os registros se estenderam por mais 20 minutos.

Nos animais acordados, após 24 h de recuperação, PA e fluxo sanguíneo do trem posterior basais foram registrados. A seguir, foi administrada amioda- rona ou veículo, com posterior registro de 20 minutos. Em um segundo grupo de animais, prazosin $(1 \mathrm{mg} / \mathrm{kg}$, i.v.) foi administrado 20 minutos após amiodarona ou veículo, e os registros se estenderam por mais $10 \mathrm{mi}-$ nutos. Em um terceiro grupo de ratos, amiodarona foi administrada em ratos pré-tratados com losartan (10 $\mathrm{mg} / \mathrm{kg}$ ). Finalmente, um outro grupo de animais, amiodarona foi administrada em ratos pré-tratados com AVPant (10 mg/kg, i.v.).

Amiodarona promoveu hipotensão, bradicardia e vasodilatação nos animais anestesiados e acordados. A hipotensão foi máxima no primeiro minuto após amiodarona e recuperou-se parcialmente durante 20 minutos. A bradicardia instalou-se rapidamente após amiodarona e mostrou-se progressiva e duradoura, persistindo durante os 20 minutos de registro. Amiodarona promoveu vasodilatação no trem posterior e leito vascular mesentérico, imediatamente após sua administração. No trem posterior, esse efeito foi transitório, recuperando-se rapidamente. Porém, no leito vascular mesentérico, esse efeito foi duradouro, permanecendo durante os 20 minutos de registro.

A administração de prazosin promoveu hipotensão e vasodilatação nos animais tratados com amiodarona ou veículo. A hipotensão foi mais pronunciada nos animais tratados com veículo. A vasodilatação promovida pelo prazosin foi maior nos animais tratados com veículo embora, não tenham sido encontradas diferenças estatisticamente significantes entre os 
dois grupos. O pré-tratamento com losartan ou AVPant não modificou os efeitos da amiodarona sobre a PA, FC e resistência vascular do trem posterior.

O presente estudo demonstrou que a amiodarona administrada endovenosamente promove hipotensão, bradicardia e vasodilatação em animais anestesiados e acordados. O efeito vascular da amiodaro- na é transitório mas seu efeito sobre a freqüência cardíaca é duradouro, sugerindo que a hipotensão esteja sendo mantida pelas ações cardíacas da droga. A recuperação da resistência vascular do trem posterior parece ser independente de receptores adrenérgicos $\mathrm{a}_{1}$, receptores $\mathrm{AT}_{1}$ da angiotensina II e receptores $\mathrm{V}_{1}$ da vasopressina.

\section{EXPRESSÃO TEMPORO-ESPACIAL DE C-FOS EM ESTRUTURAS CEREBRAIS RELACIONADAS COM A NOCICEPÇAO E ANTINOCICEPÇÃO DURANTE MOVIMENTAÇÃO DOS INCISIVOS SUPERIOR DE RATOS}

\section{Peterson Joviliano}

Orientadora: Profa. Dra. Maria José Alves da Rocha Dissertação de Mestrado apresentada em 26/04/2006

A expressão de $c$-fos foi analisada em neurônios do complexo trigeminal e dos núcleos: Substância Cinzenta Periaquedutal (SCP), Dorsal da Rafe (DR) e Núcleo Parabraquial (PB) para revelar as mudanças temporais durante movimentação dentária experimental, produzida por um aparelho ortodôntico ativado ou não com força inicial de 70g. Ratos Wistar, machos e adultos, foram anestesiados (i.m.) com Ketamina e Xilazina e divididos em 3 grupos: animais que receberam os aparelhos ortodônticos previamente ativados (cf), animais que receberam o aparelho sem ativação (sf) e ainda, animais que receberam o aparelho previamente ativado, mas este foi removido imediatamente após a sua inserção (c). Após 6, 24, 48 e 72 horas da instalação do aparelho, os animais foram anestesiados novamente e posteriormente, perfundidos com PBS e paraformaldeído. A seguir, os encéfalos foram removidos e pós-fixados e estocados por no máximo 72 horas. Cortes encefálicos foram processados para ensaios de imunocitoquímica objetivando a análise da expressão de $c$-fos em estruturas nociceptivas e antinociceptivas. Os resultados demonstraram que a expressão de c-fos é diferente entre os três grupos analisados (cf, sf, c), sugerindo que a simples instalação do aparelho ortodôntico é suficiente para induzir ativação neuronal que se torna mais intensa quando se aplica $70 \mathrm{~g}$ de força. O trabalho demonstrou ainda que a movimentação dentária induziu expressão de $c$-fos em estruturas cerebrais envolvidas com nocicepção e antinocicepção sendo que em algumas delas esta expressão segue o padrão temporal das sensações relatadas em estudos clínicos.

\section{RESPOSTAS HEMODINÂMICAS À ESTIMULAÇÃO DO NERVO DEPRESSOR AÓRTICO EM RATOS NORMOTENSOS E ESPONTANEAMENTE HIPERTENSOS (SHR)}

\section{Alvaro Ribeiro Barale \\ Orientador: Prof. Dr. Hélio César Salgado \\ Tese de Doutorado apresentada em 18/05/2006}

As respostas barorreflexas produzidas pelas variações da pressão artéria estão atenuadas nos ratos espontaneamente hipertensos (SHR). Foi sugerida a hipótese de que as respostas reflexas à estimulação das aferências barorreceptoras do nervo depressor aórtico (NDA), efetivamente contornando a transdu- ção mecano-sensorial, estão preservadas nos SHR acordados. A pressão arterial média (PAM), frequiência cardíaca (FC) e as resistências vasculares regionais (trem posterior e mesentérica) foram medidas antes e durante a estimulação do NDA durante $5 \mathrm{~s}$ com freqüências aleatórias $(5,10,15,30,50,70$ e 90 $\mathrm{Hz})$, em SHR acordados $(\mathrm{n}=18)$ e ratos normotensos controles ( $\mathrm{RNC}, \mathrm{n}=18)$. O protocolo foi repetido após bloqueio dos receptores of $\beta_{1}$-adrenérgicos com atenolol. Os SHR apresentaram níveis basais elevados PAM ( $150 \pm 5$ vs. $103 \pm 2 \mathrm{mmHg}$ nos RNC) e FC (393 \pm 9 
vs. $360 \pm 5 \mathrm{mmHg}$ nos RNC). A latência das respostas de FC, PAM e resistências vasculares (trem posterior e mesentérica) foi a mesma em SHR e RNC. A resposta hipotensora frequência-dependente à estimulação do NDA foi preservada, ou até aumentada, nos SHR comparada com a do RNC. As maiores quedas absolutas da PAM, que ocorreram em altas frequiên-

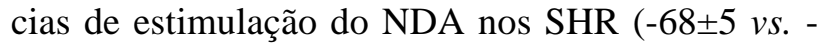
$38 \pm 3 \mathrm{mmHg}$ nos RNC com $90 \mathrm{~Hz}, \mathrm{P}<0.05)$ foram associadas com a queda preferencial de resistência vascular do trem posterior $(-43 \pm 5 \%)$ vs resistência mesentérica $(-27 \pm 3 \%)$ nestes animais. Ao contrário, a estimulação do NDA reduziu de forma equivalente as resistências do trem posterior e mesentérica nos RNC (-33 $\pm 7 \%$ e $-30 \pm 7 \%$, respectivamente). A redução frequência-dependente na FC foi também preservada nos SHR, embora o mecanismo da bradicardia tenha sido diferente. $\mathrm{O}$ atenolol atenuou significa- tivamente a bradicardia nos SHR $(-88 \pm 14$ vs. $-129 \pm 18$ bpm, com $90 \mathrm{~Hz}$ de estimulação, $\mathrm{P}<0.05)$, mas não alterou a bradicardia nos RNC (-116 \pm 16 vs. $-133 \pm 13$ $\mathrm{bpm}$ ). A bradicardia barorreflexa residual na presença de atenolol (componente parassimpático) foi significativamente reduzida nos SHR quando comparado aos RNC ( $\mathrm{P}<0.05)$. Os resultados indicam que: 1$)$ as quedas de PAM e FC em resposta à estimulação elétrica do NDA estão mantidas em SHR em comparação com os RNC acordados; 2) o mecanismo responsável pela hipotensão tem modulação diferente, sendo preferencialmente maior no trem posterior do SHR; 3) a retirada barorreflexa do tono simpático complementa a atenuação do parassimpático no controle da FC dos SHR. Pode-se concluir que, contornando a transdução mecano-sensorial, a estimulação elétrica das aferências barorreceptoras efetivamente reduz a PAM e FC nos SHR acordados.

\section{A ATUAÇÃO DO INIBIDOR DA SÍNTESE DE ÓXIDO NÍTRICO SOBRE A AÇÃO DA NEUROTOXINA 6-HIDROXIDOPAMINA É DEPENDENTE DA GRAVIDADE DA LESÃO INDUZIDA}

\section{Margarete Zanardo Gomes}

Orientadora: Profa. Dra. Elaine A. Del Bel B. Guimaraes Tese de Doutorado apresentada em 19/05/2006

O Óxido Nítrico (NO) desempenha papel no controle da atividade motora, inclusive nos circuitos dos gânglios basais. Os objetivos deste trabalho foram analisar se a inibição da enzima de síntese do NO influenciaria a lesão da via nigroestriatal causada pela toxina 6-hidroxidopamina (6-OHDA) no feixe prosencefálico medial e no neoestriado de ratos. Para analisar o efeito da inibição do NO sobre a lesão aplicação de 6-OHDA grupos de animais receberam tratamento sub-crônico com NG-nitro-L-Arginina (L-NOARG) i.p. $40 \mathrm{mg} / \mathrm{kg}$ ou salina durante 5 dias, sendo que ao segundo dia de tratamento foi realizada cirurgia para micro injeção da 6-OHDA ou veículo. Estes animais foram sacrificados 35 dias após o procedimento cirúrgico. Para analisar o efeito da inibição do NO no decurso temporal das alterações causadas pela aplicação de 6-OHDA no feixe prosencefálico medial, outro grupo de animais recebeu uma única injeção de L-NOARG na dose $100 \mathrm{mg} / \mathrm{kg}$ ou salina i.p. no dia da cirurgia e os animais foram sacrificados nos tempos 24 e 96 horas, bem como 20 e 35 dias após cirurgia. Todos os animais sacrificados aos trinta e cinco dias foram submetidos ao teste do campo aberto e teste de comportamento rotatório. Após o sacrifício foi realizada análise da imunocitoquímica para tirosina hidroxilase (TH) e da sintase do óxido nítrico (NOS). Os resultados do teste do campo aberto mostraram que ocorreu diminuição no comportamento exploratório em ambos os modelos de lesão, sendo que o tratamento com inibidor da NOS na dose $100 \mathrm{mg} / \mathrm{kg}$, concomitante à lesão do feixe prosencefálico medial, aumentou este efeito. Animais que receberam 6-OHDA em ambos os sítios manifestaram giros contra laterais à lesão, no entanto, o número de giros foi maior em animais submetidos à lesão no feixe. A imunocitoquímica para TH neste grupo evidenciou perda total de marcação na substância negra compacta, área tegmental ventral e núcleo caudado/putâmen, independente do tratamento i.p. Animais que receberam lesão no neoestriado ou não apresentaram perda de marcação para TH ou apresentaram redução apenas nas porções lateral da substância negra compacta e na porção dorso-lateral caudal no núcleo. O tratamento subcrônico com L-NOARG promoveu um aumento no número de giros aos 15 dias nos animais com lesão no feixe. Já nos animais com lesão no neoestriado observou-se que o inibidor da NOS não afetou ou diminuiu o comportamento rotatório aos trinta dias, de acordo 
com o grupo experimental. A densidade de células e terminais marcados nos animais com lesão neoestriatal que receberam L-NOARG $(40 \mathrm{mg} / \mathrm{kg}$, sub-crônico) não foi diferente da observada nos animais do grupo controle, sugerindo um efeito protetor pela inibição da NOS. Quanto à avaliação do decurso temporal da lesão causada pela toxina 6-OHDA, os resultados mostraram diminuição na imunorreatividade na área tegmental ventral e na substancia negra compacta lateral, às 24 horas e na substância negra compacta porções medial e lateral às 96 , horas apenas nos animais que receberam aplicação de 6-OHDA acompanhada de tratamento com salina i.p. Não foram observadas alterações significantes em tempos posteriores de sacrifício. Finalmente, a análise imunocitoquímica para NOS evidenciou aumento na densidade de neurônios marcados no núcleo caudado/putâmen ipsi e contra laterais e também diminuição na área tegmental ventral ipsilateral em ambos os modelos de lesão. A lesão no feixe induziu ainda uma diminuição da densidade de células marcadas para NOS no núcleo acumbens e substância negra compacta ipsi laterais à lesão. Adi- cionalmente, um aumento da densidade de neurônios marcados no núcleo caudado/putâmen foi observado já nas primeiras 24 horas após a lesão, já a diminuição ao nível dos corpos neuroniais da substância negra e área tegmental ventral foi observada apenas após 20 dias de aplicação da toxina. O tratamento sub-crônico com L-NOARG $40 \mathrm{mg} / \mathrm{kg}$ não modificou os efeitos da lesão no feixe prosencefálico medial sobre a densidade de neurônios marcados para NOS. Em contrapartida, a densidade de neurônios marcados para NOS no núcleo caudado e na área tegmental ventral em animais com lesão no neoestriado que receberam o L-NOARG não diferiu da observada nos controles. O tratamento agudo com L-NOARG $100 \mathrm{mg} / \mathrm{kg}$ também promoveu uma reversão do efeito da lesão no aumento da densidade de células marcadas no caudado/putâmen às 24 horas e também em um aumento no globo pálido interno às 96 horas. Em conclusão, estes resultados indicam que a influencia da inibição do NO na lesão da via nigroestriatal depende da extensão da lesão induzida e sugerem um possível papel tóxico do NO na evolução do processo degenerativo.

\section{MODULADORES ENVOLVIDOS NA LIBERAÇÃO DO PEPTÍDEO NATRIURÉTI- CO ATRIAL (ANP) E OCITOCINA (OT) EM RESPOSTA A ESTIMULAÇÃO OSMÓTICA DO HIPOTÁLAMO BASAL in vitro}

\section{Dayane Aparecida Gomes}

Orientador: Prof. Dr. José Antunes Rodrigues

Tese de Doutorado apresentada em 23/05/2006

Neste estudo, investigamos a participação do monóxido de carbono $(\mathrm{CO})$ e do óxido nítrico como modulador da secreção do peptídeo natriurético atrial (ANP) e ocitocina (OT) pelo hipotálamo anterior e médio basal (HB) em condições de iso e hiperosmolalidade. Os resultados demonstram que a hiperosmolalidade induz aumento significativo na liberação de ANP e OT. O uso de doador de NO, inibe tanto a liberação de ANP como de OT induzida pela hiperosmolalidade e esta resposta é mediada pela ativação da guanilato ciclase (GC) e geração de GMPc. Ainda, a inibição da heme-oxigenase com ZnDPBG e ZnPPIX determinou aumento significativo na atividade da NOS e diminuição da secreção de ANP e OT em condição isosmótica e durante a estimulação hipertônica. A inibição da secreção hormonal é bloqueada com o uso do inibidor da GC sugerindo que a ação inibitória do
ZnDPBG e ZnPPIX é em parte mediada pela ativação do sistema GC-GMPc. No presente trabalho também avaliamos a participação do glutamato como modulador da secreção de ANP e OT. Os resultados demonstram que a estimulação do receptor NMDA aumenta a atividade NOS e a secreção de ANP e OT. A inibição do receptor NMDA com o uso de um antagonista específico (CPP) bloqueou o aumento da secreção de ANP e OT induzido pela hiperosmolalidade, sugerindo que a secreção de ANP e OT é mediada pela ativação do receptor NMDA. Apresentamos também, evidências experimentais do papel do cálcio sobre a secreção de ANP. O uso de um quelante de cálcio extracelular (EGTA) diminuiu enquanto o ionóforo de cálcio (ionomicina) aumentou a secreção de ANP em condição isomótica bem como hiperosmótica pelo hipotálamo basal in vitro e em cultura de neurônios hipotalâmicos. Em conclusão, este estudo demonstra o papel dos sistemas NO/CO, cálcio e glutamato na modulação da secreção do ANP e OT pelo BH sob estimulação osmótica. 


\section{VIAS EFETORAS NO CONTROLE DA TERMOGÊNESE E TERMORREGULA- ÇÃO COMPORTAMENTAL: PARTICIPAÇÃO DO LOCUS COERULEUS E NÚ- CLEO HIPOTALÂMICO DORSOMEDIAL}

\section{Maria Camila Almeida}

Orientador: Prof. Dr. Luiz G. de Siqueira Branco

Tese de Doutorado apresentada em 08/06/2006

A presente tese está dividida em dois estudos principais, No Estudo $\boldsymbol{N}^{\boldsymbol{o}} \boldsymbol{1}$ (Participação do LC no controle da atividade termoefetora autonômica durante a resposta febril em ratos), nós estudamos o envolvimento do principal núcleo noradrenérgico do sistema nervoso central, o locus coeruleus (LC), na febre induzida por lipopolissacarídeo (LPS). Ratos Wistar tiveram o LC completamente destruído por lesões eletrolíticas ou os neurônios catecolaminérgicos destruídos pela lesão química seletiva com 6-hidroxidopamina (6-OHDA); os controles foram submetidos à lesão fictícia do LC. Tanto a lesão eletrolítica quanto a lesão com 6-OHDA resultou em atenuação da resposta febril induzida pelas doses de 1 e $10 \mu \mathrm{g} / \mathrm{kg}$ de LPS, em ratos expostos à temperatura ambiente $\left(\mathrm{T}_{\mathrm{a}}\right)$ de $23^{\circ} \mathrm{C}$. Como as lesões química e eletrolítica produziram resultados semelhantes, os experimentos subseqüentes foram realizados em animais com lesão eletrolítica. Os níveis de prostaglandina $(\mathrm{PG}) \mathrm{E}_{2}$, mediador final da sinalização aferente durante a febre, aumentaram de maneira semelhante na região anteroventral do terceiro ventrículo de ratos controle e com lesão do LC, indicando que este núcleo não está envolvido nos mecanismos de sinalização aferente durante a febre. A fim de investigar a participação do $\mathrm{LC}$ na via termorregulatória eferente, a resposta termorregulatória à $\mathrm{PGE}_{2}$ (25 ng, i.c.v.) foi estudada em ratos expostos a $\mathrm{T}_{\mathrm{a}}$ subneutra $\left(23^{\circ} \mathrm{C}\right.$, quando a febre ocorre devido à ativação da termogênese) ou neutra $\left(28^{\circ} \mathrm{C}\right.$, quando a febre ocorre devido à vasoconstrição periférica). $\mathrm{O}$ aumento no consumo de oxigênio (índice de termogênese) e $\mathrm{T}_{\mathrm{c}}$ induzidos por $\mathrm{PGE}_{2}$ foram atenuados em ratos com lesão do $\mathrm{LC}$ expostos à $\mathrm{T}_{\mathrm{a}}$ subneutra $\left(23^{\circ} \mathrm{C}\right)$. A febre induzida por $\mathrm{PGE}_{2}$ (que foi acompanhada de vasoconstrição periférica), foi semelhante em ratos controle e com lesão do LC expostos à $\mathrm{T}_{\mathrm{a}}$ de $28^{\circ} \mathrm{C}$. Os ratos com lesão do LC mostraram-se perfeitamente capazes de aumentar o consumo de oxigênio em resposta a infusão de norepinefrina e manter a $T_{c}$ em resposta a exposição ao frio. Nossos resultados mostram que os neurônios catecolaminérgicos do LC fazem parte de uma via neuronial termoefetora que é especificamente ativada por pirogênios (como LPS e $\mathrm{PGE}_{2}$ ) para aumentar a termogênese e desenvolver febre.
No Estudo $\boldsymbol{N}^{\boldsymbol{o}} 2$ (Efeito das lesões de áreas hipotalâmicas na termorregulação comportamental em ratos), o envolvimento de três estruturas hipotalâmicas - área pré-óptica (POA), núcleo paraventricular $(\mathrm{PVN})$ e núcleo dorsomedial (DMH) - no comportamento de seleção da temperatura ambiente $\left(\mathrm{T}_{\mathrm{a}}\right)$ de preferência foi estudado em ratos em um gradiente de temperatura $\left(\mathrm{T}_{\mathrm{a}}\right.$ de 15 a $\left.30^{\circ} \mathrm{C}\right)$. Os ratos foram extensivamente habituados ao aparato e sofreram lesão eletrolítica bilateral da POA, PVN e DMH. Outro grupo de animais sofreu lesão bilateral química (com ácido ibotênico) do PVN e DMH. Para injeção das drogas foi implantado um cateter na veia jugular; para medidas de temperatura corporal $\left(\mathrm{T}_{c}\right)$ foi implantado um datalogger de temperatura na cavidade abdominal dos ratos. Mudanças na $T_{c}$ e $T_{a}$ de preferência foram avaliadas em ratos que sofreram estímulo térmico (exposição ao frio e calor), químico [injeção de resiniferatoxina (RTX, agonista TRPV1; $0,5 \mu \mathrm{g} / \mathrm{kg}$ I.V.) ou mentol (agonista TRPM8; $50 \mu \mathrm{g} / \mathrm{kg}$, I.V.)], ou inflamatório [injeção de lipopolissacarídeo (LPS nas doses de 10 ou $5.000 \mu \mathrm{g} / \mathrm{kg}$, I.v.)]. Nos animais controle (lesão fictícia) a exposição ao frio, injeção de mentol e LPS na dose de $10 \mu \mathrm{g} / \mathrm{kg}$ induziram comportamento de procura por calor, enquanto que exposição ao calor, injeção de RTX e LPS na dose de $5.000 \mu \mathrm{g} / \mathrm{kg}$ induziram comportamento de procura por frio. As respostas comportamentais induzidas por exposição ao frio e calor, injeção de mentol e RTX e LPS na dose de $10 \mu \mathrm{g} / \mathrm{kg}$ não foram afetadas em animais com lesão eletrolítica da POA, PVN, ou DMH, embora ratos com lesão eletrolítica da POA apresentaram deficiência termorregulatória autonômica durante exposição ao frio e calor e ratos com lesão do DMH apresentaram deficiência termorregulatória autonômica durante exposição ao frio. O comportamento de procura por frio e hipotermia induzidos por LPS na dose de $5.000 \mu \mathrm{g} / \mathrm{kg}$ foi praticamente abolido em animais com lesão eletrolítica do PVN e DMH (mas não da POA). $\mathrm{O}$ comportamento de procura por frio induzido por LPS foi atenuado em animais com lesão química do DMH, mas não do PVN. Esses resultados mostram que os corpos celulares localizados no DMH e fibras de passagem do PVN participam do comportamento de procura por frio induzido por estímulo inflamatório forte, como alta dose de LPS. Confirmando vários estudos anteriores, mostramos que a POA é importante para o desenvolvimento de respostas termorregulatórias autonômicas, mas não comportamentais. 


\section{MECANISMOS ANGIOTENSINÉRGICOS ENVOLVIDOS NA MODULAÇÃO DO COMPONENTE SIMPATO-EXCITATÓRIO DO QUIMIORREFLEXO NO BULBO VENTROLATERAL E NO NÚCLEO DO TRATO SOLITÁRIO DE RATOS}

\section{Luciano Gonçalves Fernandes}

Orientador: Prof. Dr. Benedito Honorio Machado

Tese de Doutorado apresentada em 14/06/2006

A ativação do quimiorreflexo promove, dentre outras respostas, aumento da atividade eferente simpática que se traduz em aumento da pressão arterial. Vários estudos na literatura mostram que diversas áreas do sistema nervoso central, como o núcleo do trato solitário (NTS) e o bulbo rostral-ventrolateral (RVLM) estão envolvidas na neurotransmissão e/ou resposta neuromodulação da simpato-excitatória do quimiorreflexo. Estudos de nosso laboratório têm demonstrado que a resposta pressora à ativação do quimiorreflexo foi ser bloqueada pelo antagonismo de receptores do neurotransmissor L-Glutamato no NTS ou no RVLM. Diversos estudos têm demonstrado que a angiotensina participa da neurotransmissão excitatória dos núcleos que fazem parte das vias neurais do quimiorreflexo. No presente estudo avaliamos a participação de mecanismos angiotensinérgicos na neuromodulação do componente simpato-excitatório do quimiorreflexo no NTS e no RVLM, utilizando diferentes abordagens metodológicas: 1) Estudos de microinjeções do Sartran (antagonista dos receptores de angiotensina) no RVLM de animais acordados, onde observamos que o bloqueio bilateral dos receptores de angiotensina do RVLM atenuou a resposta pressora à ativação do quimiorreflexo em animais acordados, mostrando uma participação destes receptores na neuromodulação da via simpato-excitatória do quimiorre- flexo no RVLM. Observamos também que o bloqueio bilateral dos receptores de angiotensina do RVLM não promoveu queda da pressão arterial basal em animais acordados; Este conjunto de resultados nos permite concluir que a angiotensina e seus receptores participam da neuromodulação da resposta simpato-excitatória do quimiorreflexo no RVLM; 2) estudos eletrofisiológicos em neurônios do NTS dissociados mecanicamente, onde documentamos que a aplicação exógena de angiotensina II promove aumento, redução ou ausência de alteração tanto na amplitude quanto na freqüêencia correntes excitatórias e inibitórias póssinápticas espontâneas; e 3) experimentos eletrofisiológicos em neurônios do NTS contidos em fatias horizontais do tronco cerebral, os quais sugerem que a aplicação exógena de angiotensina II promove três padrões de respostas eletrofisiológicas para os eventos excitatórios espontâneos e para eventos excitatórios evocados pela estimulação elétrica do Trato Solitário: excitação, inibição ou ausência de alteração. Os resultados dos experimentos de eletrofisiologia documentaram a presença e diferentes padrões de respostas à ativação dos receptores de angiotensina no NTS, nos permitindo sugerir que a angiotensina pode promover uma grande diversidade de efeitos nos neurônios do NTS. 4) Experimentos em animais acordados sugerem que os receptores de angiotensina do NTS não participam da resposta simpato-excitatória do quimiorreflexo em ratos acordados, pois o bloqueio dos receptores de angiotensina nesse núcleo não alterou a resposta pressora do quimiorreflexo.

\section{EFEITOS DA EXPANSÃO DO VOLUME EXTRACELULAR SOBRE A ATIVAÇÃO NEURONAL E SECREÇÃO HORMONAL: MODULAÇÃO PELO EIXO HIPOTÁLAMO-HIPÓFISE-ADRENAL}

\section{Silvia Graciela Ruginsk}

Orientador: Prof. Dr. José Antunes Rodrigues

Dissertação de Mestrado apresentada em 29/06/2006

A manutenção constante do volume e da composição dos líquidos corporais, definida como homeostase hidreletrolítica, é essencial para a sobrevida dos organismos. Quando ocorre alguma alteração no meio interno, o organismo promove ativação de mecanismos e vias neurais seletivas para o controle da ingestão e excreção de água e eletrólitos, visando manter a composição e o volume dos líquidos corporais compatíveis com a adequada manutenção das funções orgânicas. Os neurônios magnocelulares, localizados nos núcleos paraventricular (NPV) e o supra-óptico (NSO) do hipotálamo, estão sabidamente envolvidos nos meca- 
nismos que controlam a homeostase hidreletrolítica. Estes núcleos hipotalâmicos são responsáveis pela síntese e liberação dos hormônios vasopressina (AVP) e ocitocina (OT) que, juntamente com o peptídeo natriurético atrial (ANP), estão envolvidos nas respostas renais a alterações do volume ou da osmolalidade do líquido extracelular (LEC). Além disso, estudos desenvolvidos anteriormente em nosso laboratório sugeriram que essas alterações são estímulos potencialmente estressores, capazes de levar à ativação do eixo hipotálamo-hipófise-adrenal (HHA). Portanto, o presente trabalho visou avaliar o padrão de resposta hormonal e ativação dos neurônios magnocelulares do NPV e NSO no modelo experimental que utiliza a expansão do volume extracelular (EVEC), procurando destacar a participação do eixo HHA na mediação destas respostas. Os resultados apresentados mostram que a EVEC isotônica $(\mathrm{NaCl} 0,15 \mathrm{M}, 2 \mathrm{ml} / 100 \mathrm{~g}$ p.c., e.v.) promoveu aumento na secreção de OT, ANP e corticosterona, e diminuição na secreção de AVP, enquanto que a EVEC hipertônica $(\mathrm{NaCl} 0,30 \mathrm{M}, 2 \mathrm{ml} /$ $100 \mathrm{~g}$ p.c., e.v.) promoveu aumento nas concentrações plasmáticas de AVP, OT, ANP e corticosterona. Ambos os tipos de EVEC também promoveram aumento na ativação de neurônios magnocelulares ocitocinér- gicos localizados no NPV e NSO. O pré-tratamento com dexametasona ( $1 \mathrm{mg} / \mathrm{kg}$ i.p.), um glicocorticóide sintético, foi capaz de inibir a secreção de OT, bem como a ativação neuronal desencadeada pela EVEC isotônica e hipertônica. A adrenalectomia prévia (5-7 dias antes do experimento), contudo, foi capaz de potencializar a secreção de OT observada em resposta a ambos os tipos de EVEC. Os resultados mostram ainda que a administração prévia de dexametasona não alterou a secreção de AVP em resposta à EVEC isotônica ou hipertônica, apesar de ter exercido um efeito aparentemente inibitório sobre a ativação dos neurônios magnocelulares vasopressinérgicos do NPV e NSO. A adrenalectomia preveniu a queda na secreção de AVP normalmente observada em resposta à EVEC isotônica, não alterando os valores observados em resposta à EVEC hipertônica. Por sua vez, a secreção do ANP não foi modificada pelo prétratamento com dexametasona ou pela adrenalectomia prévia. Em conjunto, esses dados sugerem que a ativação do eixo HHA exerce um controle diferenciado sobre a síntese e secreção dos hormônios neuro-hipofisários OT e AVP e que esta ativação não influi no controle da secreção de ANP em resposta à EVEC.

\section{GENÉTICA}

\section{ANÁlISE DA EXPRESSÃo GÊNICA NO PISTILO DE NICOTIANA TABACUM: IDENTIFICAÇÃO DE GENES ESPECÍFICOS POR HIBRIDIZAÇÃO SUBTRATIVA E CARACTERIZAÇÃO TEMPORAL E CELULAR}

\section{Henrique Cestari De Paoli}

Orientadora: Profa.Dra.Maria Helena Souza Goldmann Dissertação de Mestrado apresentada em 11/04/2006

O sucesso da reprodução das plantas depende da função do pistilo em receber e discriminar os grãos de pólen, tanto quanto proporcionar as condições apropriadas para o crescimento do tubo polínico. Identificar e caracterizar genes especificamente expressos no pistilo são a chave para um melhor entendimento desses processos ao nível molecular. Com esse propósito, foi construída uma biblioteca subtrativa suprimida (SSH1) utilizando cDNA de estigma/estilete como "tester" e cDNA de raiz, caule, folha, sépala e pétala como "driver". Para validar a biblioteca, utilizou-se uma sonda para o gene de uma metiltransferase, específico de pistilo, previamente identificado e caracterizado por nosso grupo de trabalho (ANGELO, 2001). Após esta validação, foram seqüenciados 1651 clones, gerando 984 ESTs com valor de Phred/Phrap $>20$. Estas, foram agrupadas pelo CAP3, resultando em 147 singlets e 81 contigs. Alguns desses agrupamentos eram redundantes entre si, totalizando 192 transcritos distintos. A análise dessas sequiências, usando os programas BlastX e BlastN, mostrou que 128 sequiências eram similares a outras já caracterizadas 
e depositadas em bancos de dados internacionais. Por outro lado, 21 seqüências codificavam proteínas hipotéticas e 43 não tinham similaridade significativa, resultando em 33,3\% de seqüências novas. Uma análise adicional no banco de dados TOBEST (TOBacco ESTs), que é constituído de 4.930 transcritos de estigma/estilete de Nicotiana tabacum, demonstrou identidade com somente 100 transcritos, enquanto que as 92 sequiências restantes $(47,9 \%)$ não haviam sido ainda identificadas no estigma/estilete dessa planta e, talvez, correspondam a transcritos de baixa abundância. A análise in silico de sublocalização celular, feita a partir da tradução dos transcritos, revelou que a maioria das proteínas $(24,16 \%)$ estava sendo direcionada para o meio extracelular/membrana plasmática, além das proteínas que estavam sendo direcionadas para o citoplasma, vacúolo, núcleo, mitocôndria, cloroplasto e retículo endoplasmático. Para confirmar a expressão diferencial dos genes identificados na biblioteca, cinco clones foram selecionados para a análise por RT-PCR em tempo real, validando a expressão preferencial de estigma/estilete de quatro transcritos, e preferencial de órgão reprodutor dos cinco genes. Dentre estes, o transcrito (NtHT) com homologia ao gene da proteína HT de $N$. alata, se mostrou específico de pistilo e tem uma expressão mais de 50 vezes maior no estigma/ estilete quando comparado ao ovário. Ao mesmo tempo, o estigma/estilete de plantas transgênicas STIG1:
Barnase, nas quais a zona secretória do estigma está ausente, demonstrou uma expressão significativamente menor que a das plantas selvagens. Isto sugere a presença deste transcrito, de uma forma preferencial, nas células que compõem este tecido deletado. Adicionalmente, a análise da expressão deste gene, durante os doze estágios do desenvolvimento floral, exibiu um padrão transcricional desde o estágio 6 até o estágio 12, com um nível máximo de expressão no estágio 10. Paralelamente, foram realizados experimentos de hibridização in situ e detectou-se a presença deste transcrito nos tecidos especializados do pistilo, atravessados pelo tubo polínico durante seu crescimento em direção ao óvulo. Similarmente, visualizou-se um forte sinal nas células do tegumento externo do óvulo, próximo à micrópila, que interagem com a superfície do tubo polínico, além do funículo e da parede do carpelo, de papel principalmente estrutural.

Dessa forma, foi proposta uma direção, em função dos mecanismos que coordenam a interação pólen-pistilo, principalmente no estigma úmido. Além disso, foi feita a caracterização molecular do gene NtHT, homólogo ao gene NaHT, previamente proposto como envolvido na auto-incompatibilidade em $N$. alata. Entretanto, nossos resultados sugerem uma função mais geral do produto desse gene na reprodução de plantas, assim como para a reprodução de $N$. tabacum, uma espécie auto-compatível.

\section{ESTUDOS MOLECULARES DE TUMORES E PROCESSOS PRÉ-NEOPLÁSICOS DA MAMA HUMANA}

\section{Nacibe Abutrab}

Orientadora: Profa. Dra. Cacilda Casartelli

Dissertação de Mestrado apresentada em 02/05/2006

O câncer de mama é o mais freqüente em incidência e mortalidade no sexo feminino. O número de casos novos de câncer de mama esperados para o Brasil em 2006 é de 48.930, com um risco estimado de 52 casos a cada 100 mil mulheres. A carcinogênese constitui-se um processo de múltiplos passos, caracterizado pela ocorrência ou acúmulo de alterações genéticas e epigenéticas. O perfil particular dessas alterações em cada tumor é responsável pela heterogeneidade no comportamento tumoral e pelas diferentes respostas ao tratamento, observadas em cada paciente. $\mathrm{O}$ conhecimento das alterações moleculares específicas será crucial para a identificação de novos alvos terapêuticos e estratégias de prevenção. Os objetivos do trabalho foram analisar o espectro mutacional da região codificadora do gene PTEN em quarenta amostras de tumores e processos pré-neoplásicos da mama humana, bem como avaliar o perfil de metilação da região promotora do gene MLH1 nas mesmas amostras. Para análise do gene PTEN os nove éxons foram amplificados por PCR e posteriormente analisados por SSCP, porém não foram encontradas alterações no padrão de migração. Para avaliar o perfil de metilação do MLH1, foi utilizado o método de PCR por metilação específica. Nosso resultado apresentou metilação em quatro amostras do grupo de processos pré-neoplásico e três amostras de carcinomas ductais infiltrantes. Desta forma, pode- 
mos sugerir que mutações no gene PTEN não representam pontos críticos para a gênese e evolução no câncer de mama esporádico, e que a hipermetilação da região promotora do gene MLH1, além de participar da progressão pode também estar envolvida na gênese do câncer de mama.

\section{ESTUDOS GENÉTICOS E EPIGENÉTICOS EM ADENOCARCINOMA GÁSTRICO}

\section{Eleonidas Moura Lima}

Orientadora: Profa.Dra. Cacilda Casartelli

Tese de Doutorado apresentada em 03/05/2006

Em princípio, o câncer origina-se através de alterações genéticas e epigenéticas que ocorrem em genes específicos em determinado tipo celular. A ocorrências dessas alterações envolve ganho de função, se acometem oncogenes, perda, se ocorrem em genes supressores de tumor, e comprometimento da manutenção da integridade genômica, caso os genes afetados sejam os genes de reparo do DNA. O câncer gástrico é o terceiro mais freqüente tumor maligno no mundo. No Brasil, estima-se que em 2006 ocorrerão aproximadamente 23.200 casos novos. Segundo a classificação de Laurén, eles são divididos em: adenocarcinoma gástrico tipo intestinal e tipo difuso. Estudos sugerem que há duas vias para a carcinogênese gástrica humana envolvendo classes de genes que sofrem alterações genéticas e epigenéticas: a via mutadora, que envolve genes relacionados direta ou indiretamente com mecanismo de reparo do DNA, e a via supressora, que engloba genes relacionados com mecanismo de supressão tumoral. O presente estudo avaliou alterações genéticas e epigenéticas em câncer gástrico de prováveis genes envolvidos tanto na via mutadora quanto na via supressora. A avaliação genética consistiu na triagem mutacional por PCRSSCP do gene PTEN e posterior confirmação da mutação por seqüenciamento. Como o gene PTEN é considerado um gene supressor de tumor, ele provavelmente participaria da via supressora na carcinogênese gástrica. Porém nossos resultados corroboram a hipótese, que alterações somáticas no gene PTEN são eventos raros em câncer gástrico. A avaliação epigenética foi realizada por meio do estudo do padrão de metilação do DNA dos genes DNMT3A, DNMT3B, DNMT3L, MLH1, PMS2, MSH2, MSH6, ANAPC1, RUNX, TP53 e P16 por Metilação PCR específica e seqüenciamento para controle positivo. Analisamos e correlacionamos o perfil de metilação das DNAmetiltransferases de novo com alteração no padrão de metilação do DNA dos demais genes em estudo, pois geralmente as regiões de ilha CpG são "protegidas" do processo de metilação nos tecidos normais e "desprotegidas" em tecido tumoral. As DNAmetiltransferases de novo metilam DNA livre de radical metil. Nossos resultados sugerem a ausência da associação entre o perfil de metilação das DNA-metiltransferases de novo e o perfil de metilação dos genes em estudo. Outro ponto em nosso estudo foi analisar prováveis genes participantes da via mutadora e via supressora para testar a aplicabilidade desse modelo em relação ao fenômeno epigenético. Sugerimos que não há distinção entre adenocarcinoma gástrico tipo intestinal e tipo difuso em relação aos prováveis genes participantes da via mutadora. Em relação à via supressora, sugerimos que o gene RUXN3 deve ser utilizado como marcador genético na distinção entre adenocarcinoma gástrico tipo intestinal e tipo difuso. Assim, o entendimento da caracterização das alterações genéticas e epigenéticas nos genes envolvidos na carcinogênese gástrica é relevante, pois a aquisição desses conhecimentos poderá ser útil na elaboração de intervenções terapêuticas. Por esse motivo, faz-se necessária uma melhor compreensão desses genes e suas vias na carcinogênese gástrica.

\section{EXPRESSÃO GÊNICA DAS PROTEÍNAS VITELOGENINA E LIPOFORINA E SEUS RECEPTORES NAS FASES VITELOGÊNICAS E NÃO VITELOGÊNICAS DE APIS MELLIFERA}

\section{Karina Rosa Guidugli Lazzarini}

Orientadora: Profa.Dra. Zilá Luz Paulino Simões

Tese de Doutorado apresentada em 03/05/2006
As proteínas vitelogenina (Vg) e lipoforina (Lp), e seus respectivos receptores (VgR e LpR) estão envolvidos nos processos reprodutivos. Em alguns in- 
setos, tanto a Vg quanto a Lp são incorporadas através de endocitose mediada por receptores, e estocadas como proteínas do ovo pelos ovócitos em crescimento. O presente trabalho teve como objetivo analisar a expressão dos genes $v g$, lp, lpr e $v g r$ em operárias de Apis mellifera com enfoque na reprodução. Inicialmente, os genes $l p, l p r$ e $v g r$ foram identificados e caracterizados. Além disso, aspectos da síntese e regulação da $\mathrm{Vg}$ também foram investigados. Em relação ao gene $v g$, os nossos resultados indicam que este apresentou uma cópia única no genoma das abelhas melíferas. O mRNA de $v g$ foi encontrado apenas nos ovários de rainhas. Larvas de ambas as castas e sexos também expressaram $v g$, o que sugere que a $\mathrm{Vg}$ pode desempenhar funções adicionais além de seu papel reprodutivo. Tratamentos hormonais in vivo mostraram que um acréscimo das concentrações de 20-hidroxiecdisona promoveram uma diminuição dos níveis do mRNA de $v g$. Em operárias adultas, o silenciamento do gene $v g$ causou um significante aumento dos títulos de hormônio juvenil, o que indica que a Vg pode participar na dinâmica hormonal. Em relação a Lp, verificamos que o mRNA de $l p$ apresentou um tamanho de cerca de $10 \mathrm{~kb}$ e que foi expresso no corpo gorduroso e em vários tecidos. O mRNA de $l p$ também foi detectado em todas as fases do desenvolvimento pré-imaginal de operárias. A proteína Lp foi encontrada em ovários e embriões, o que sugere que Lp pode funcionar como uma proteína do ovo nas abelhas melíferas. Adicionalmente, o anticorpo anti - Lp de Apis mellifera foi capaz de reconhecer as subunidades da Lp de diversas espécies de abelhas brasileiras sem ferrão. Os efeitos de fatores nutricionais sobre a expressão de $v g$ e $l p$ mostraram que uma dieta sem proteínas causou uma diminuição dos níveis do mRNA de $v g$. Por outro lado, não alterou os níveis de expressão de $l p$ em operárias adultas. $\mathrm{O}$ gene $l p r$ apresentou duas formas variantes que diferiram quanto ao domínio $O$-linked sugar. A forma variante menor $(l p r-)$ foi encontrada apenas no cérebro, enquanto que a forma variante maior $(l p r+)$ foi detectada em todos os outros tecidos e ao longo de todo o desenvolvimento pré-imaginal de operárias. A expressão tecido-específica de $v g r$ mostrou que este está presente apenas nos ovários e glândulas hipofaríngeas de operárias. Finalmente, os níveis do mRNA de $v g, l p, l p r$ e $v g r$ foram avaliados no corpo gorduroso e/ou ovários de operárias órfãs durante o processo de ativação de seus ovários. O aumento dos títulos de $\mathrm{Vg}$ na hemolinfa de operárias que apresentaram ovários ativados está relacionado com um aumento dos níveis do mRNA de $v g$ no corpo gorduroso. O mRNA de $l p$ e de $v g r$ foram detectados em maiores níveis nos ovários ativados. Já, não foram observadas diferenças nos níveis do mRNA de lpr tanto no corpo gorduroso quanto nos ovários, independente da ativação dos ovários. Assim, os nossos resultados esclarecem novas funções da Vg e abrem novas possibilidades de estudar Lp, LpR e VgR na reprodução e nos demais processos biológicos em Apis mellifera.

\section{AVALIAÇÃO MOLECULAR DO GENE_SUPRESSOR DE TUMOR PTEN EM TUMORES DE SISTEMA NERVOSO}

Aline Cuadurin Custódio

Orientadora: Profa. Dra. Cacilda Casartelli

Dissertação de Mestrado apresentada em 04/05/2006

O câncer é uma doença potencialmente letal. Os tumores se desenvolvem em células que estão se dividindo. Sua iniciação ou progressão está associada com o acúmulo de alterações genéticas. Essas alterações podem ser aberrações cromossômicas, mutações, polimorfismos e modificações epigenéticas. O câncer se desenvolve quando mecanismos de defesa do organismo sofrem alterações. Os tumores do sistema nervoso representam aproximadamente $2 \%$ de todos os tipos de câncer. O papel central do sistema nervo- so e as conseqüências funcionais da perda de neurônios podem explicar a severidade dos tumores cerebrais. A formação dos tumores do cérebro humano é um processo complexo, envolvendo um acúmulo de alterações genéticas. Os genes supressores de tumor estão envolvidos na formação de tumores. Sua perda, inativação ou disfunção leva a célula a se dividir desordenadamente, surgindo assim tumores e neoplasias no local onde elas ocorrem. O objetivo deste trabalho foi fazer uma triagem de ocorrência de polimorfismos conformacionais no gene supressor de tumor PTEN em 50 amostras de tumores de Sistema Nervoso. Nenhuma alteração mutacional foi encontrada. Nossos resultados se assemelham aos da literatura 
em relação à ausência de alterações no gene PTEN em tumores benignos; em relação aos glioblastomas, a literatura cita uma alta freqüência de alterações no gene PTEN, mas não encontramos nenhuma altera- ção nas 9 amostras estudadas. Outro mecanismo como por exemplo a metilação da região promotora, poderia estar envolvido na inativação desse gene nos tumores analisados.

\section{GENÉTICA DA DETERMINAÇÃO DE CASTAS EM MELIPONA QUADRIFASCIA- TA (HYMENOPTERA: APOIDEA)}

\author{
Gustavo Rodrigues Makert dos Santos \\ Orientador: Prof. Dr. Klaus Hartfelder \\ Tese de Doutorado apresentada em 04/05/2006
}

A participação do componente genético na determinação de castas em Melipona é motivo de muita controvérsia, mesmo meio século após sua descoberta. Como a hipótese de determinação genética de castas em Melipona ainda não havia passado por um teste experimental criterioso (suporte apenas por evidências circunstanciais), adaptamos a metodologia de AFLP para tentar solucionar esta questão intrigante. Após otimizarmos os parâmetros da metodologia para Melipona, resultados de AFLP ( 630 marcadores por colônia) revelaram um alto grau de polimorfismo genético (44\%) nas colônias, sendo que, o polimorfismo intracolonial variou de $27-38 \%$. Como a monoginia e monandria foram comprovadas em nossos experimentos por análise de microssatélites, este alto grau de polimorfismo intracolonial poderia ser resultado de uma elevada freqüência de recombinação, conforme observado em Apis mellifera.

Como conclusão principal propomos um novo modelo para determinação de castas no gênero Melipona, baseado nos resultados da análise de AFLPs com três combinações de primers, em 580 abelhas de
4 colônias de Melipona quadrifasciata. A análise dos resultados revelou a existeência de fêmeas ( 25\%) que possuem somente marcadores "ligados à casta rainha", fêmeas $(\sim 15 \%)$ que apesar de possuírem marcadores "ligados à casta rainha", possuem também marcadores "ligados à casta operária", fêmeas $(\sim 30 \%)$ que somente possuem marcadores "ligados à casta operária", e por fim, fêmeas $(\sim 30 \%)$ que não possuem nenhum marcador "ligado à casta". Apenas as fêmeas $(\sim 25 \%)$ que possuem somente marcadores "ligados à casta rainha" podem, sob condições adequadas (fatores tróficos), tornarem-se rainhas. Todas as outras fêmeas ( 75\%) tornar-se-ão operárias. Então "gene(s) ligado(s) à casta das operárias", juntamente com "gene(s) ligado(s) à casta da rainha", fariam parte de um sistema de ações pleiotrópicas, ou seja, seus produtos teriam atuações múltiplas sobre diversos tecidos e contextos, inclusive sobre outros genes (silenciamento de genes, por exemplo), onde um dos resultados seria a determinação genética de castas em Melipona quadrifasciata. Portanto, nossos resultados indicam que um modelo envolvendo vários loci (sistema multilocus) explicaria melhor o processo de determinação de castas em Melipona quadrifasciata, que o tradicional modelo genético Mendeliano de dois-loci-dois-alelos.

\section{ALTERNATIVAS PARA SELEÇÃO DE TOUROS DA RAÇA NELORE CONSIDE- RANDO CARACTERÍSTICAS MULTIPLAS DE INTERESSE ECONÔMICO}

\section{José Eduardo do Val}

Orientadora: Profa.Dra. Maria Armênia R.de Freitas

Tese de Doutorado apresentada em 25/05/2006

Este estudo foi desenvolvido a partir de informações das avaliações genéticas de touros pertencentes a rebanhos participantes do Programa de Melhoramento Genético da Raça Nelore (PMGRNNelore Brasil), que desenvolve, desde 1995, um teste de progênie denominado Reprodução Programada (RP), o qual tem como finalidade principal de disponibilizar animais com valores genéticos mais confiáveis no mercado de reprodutores. Assim, as Diferenças Esperadas nas Progênies (DEPs) de 234 touros participantes da RP no período de 1996 a 2003 foram analisadas com os seguintes objetivos: 1- Avaliar o mérito genético dos touros ao longo dos anos, utilizando regressão linear entre a DEP e ano de participação do 
touro na RP para as características, peso aos 120 e 210 dias, efeitos direto e materno (DDPP120, DDPP210, DMPP120 e DMPP210); peso e perímetro escrotal aos 365 e 450 dias, efeito direto (DDP365, DDP450, DDPE365 e DDPE450) e idade ao primeiro parto (DDIPP); 2- Identificar, por meio de abordagens multivariadas, grupos de animais cujas DEPs apresentem padrões de semelhança, assim como discriminar as variáveis que mais influenciam na divisão dos grupos, numa tentativa de auxiliar a tomada de decisão nos sistemas de produção de bovinos de corte, com vistas a maximizar a produtividade. Os procedimentos multivariados de análises de agrupamento e componentes principais foram aplicados às DEPs de sete características (DMPP120, DMPP210, DDPP365, DDPP450, DDPE365, DDPE450 e DDIPP). As análises foram processadas com o auxílio do software Statistica (STATSOFT, 2004). As tendências genéticas das DEPs relacionadas com as características de fertilidade, DDPE365, DDPE450 e DDIPP, mostraram progressos genéticos de 0,051 e $0,061 \mathrm{~cm}$ e $-0,026$ mês por ano respectivamente, enquanto que DDPP450 foi à característica que obteve maior ganho genético den- tre as DEPs de crescimento, 1,467 kg/ano. Com referência às abordagens multivariadas, a análise de agrupamento k-médias foi aplicada e o resultado envolvendo três grupos foi o melhor obtido, dos quais dois se destacaram quanto aos valores médios das DEPs. A importância desses dois grupos de touros foi confirmada pela análise de componentes principais que associou a eles valores superiores de DEPs diretas de peso e perímetro escrotal. A quantidade de variabilidade original retida pelos dois primeiros componentes principais foi de $70,22 \%$. Foram observados progressos genéticos nos touros da Reprodução Programada para todas as características durante o período estudado, indicando que a estratégia de seleção praticada vem sendo efetiva e evidenciando a importância da contribuição dos touros da RP para o melhoramento das características reprodutivas e de crescimento da raça Nelore. Neste estudo pode-se verificar o poder classificatório e discriminatório das análises de agrupamentos e componentes principais, o que muito pode contribuir na classificação de touros, facilitando a seleção de animais em Programas de Melhoramento Genético.

\section{CARACTERIZAÇÃO DA ESTRUTURA DO GENE DO microRNA miR-223: UM microRNA AMPLAMENTE EXPRESSO EM CÉLULAS HEMATOPOÉTICAS}

\section{Kelson Roberto Kodama}

Orientador: Prof. Dr. Wilson Araújo da Silva Jr. Tese de Doutorado apresentada em 06/06/2006

Os dados iniciais deste trabalho foram gerados a partir de análises computacionais (in silico) preliminares. Foi realizada a anotação dos grupos gênicos (clustrers) oriundos de um banco de seqüências ORESTES de leucemia mielóide crônica (LMC) e leucemia mielóide aguda (LMA). Uma das análises identificou um cluster de três ORESTES alinhando em Xq12, com a possibilidade de se tratar de um novo gene, em uma etapa posterior, foram desenhados primers nas extremidades da região de predição para a validação experimental por meio de RT-PCR. Com o seqüenciamento dos fragmentos gerados a partir do RT-PCR foram identificadas duas formas alternativas do gene. Foi encontrada uma homologia com seis seqüências de primatas depositadas no genebank denominadas miR-223, com identidade absoluta de $37 \mathrm{nu}-$ cleotídeos contendo a região referente ao microRNA maduro. Os microRNAs são uma família de pequenos (em torno de 22 nucleotídeos) RNAs não codificadores de proteínas encontrados em diferentes organismos. Esses pequenos RNAs atuam regulando negativamente a expressão gênica no nível pós-transcrição. Os microRNAs têm papel importante em diversas vias regulatórias, incluindo o controle do desenvolvimento, diferenciação de células hematopoéticas, apoptose, proliferação celular e organogênese. A análise da estrutura secundária mostrou o Harpin-Stem Loop, estrutura característica do pré-microRNA. A validação experimental usando PCR em tempo real detectou a presença do microRNA maduro em medula óssea normal, baço e leucemias agudas e crônicas, e ausência em outros tecidos. O PCR em tempo-real dos transcritos primários, usando sondas específicas para as duas isoformas, demonstrou uma expressão mais elevada em uma delas. Usando o método de RACE (Rápida Amplificação das Extremidades do cDNA) foi definida a região 5' e 3' do gene do microRNA miR-223. Neste trabalho nós caracterizamos a estrutura do gene do microRNA miR-223 e seus possíveis sítios de regulação de transcrição da região promotora. 


\section{GINECOLOGIA E OBSTETRÍCIA}

\section{ULTRA-SONOGRAFIA TRIDIMENSIONAL PARA ANÁLISE DE VOLUME ENDOMETRIAL DE PACIENTES SUBMETIDAS À FERTILIZAÇÃO in vitro UMA SEMANA APÓS A TRANSFERÊNCIA DE EMBRIÕES}

\section{Wellington de Paula Martins}

Orientador: Prof. Dr. Rui Alberto Ferriani

Dissertação de Mestrado apresentada em 10/04/2006

Objetivo: Determinar se, uma semana após a transferência de embrião (TE), a medida da espessura ou volume endometrial através da ultra-sonografia tridimensional (US3D) pode predizer gravidez.

Métodos: A espessura e o volume endometrial foram medidos de 40 pacientes, uma semana após a TE. O volume endometrial foi obtido pelo software VOCAL $^{\mathrm{TM}}$. Estes resultados foram comparados com o teste de detecção da fração beta da gonadotrofina coriônica humana ( $\beta$-hCG) no soro, executado uma semana após.

Resultados: Uma diferença significante entre os dois grupos foi notada tanto para a espessura quanto para o volume endometrial: grávida $(\mathrm{n}=18): 11.15 \pm$ $2.75 \mathrm{~mm} ; 6.49 \pm 1.97 \mathrm{~mL}$, não grávida $(\mathrm{n}=22): 9,77 \pm$
$1,85 \mathrm{~mm} ; 3,40 \pm 1,11 \mathrm{~mL}$ (média \pm desvio padrão). A análise da curva ROC (receiver operating characteristic) mostrou que o melhor ponto de corte para a espessura endometrial foi de $10.3 \mathrm{~mL}$ (sensibilidade de $72,2 \%$ e especificidade de $77,3 \%$ ) e para o volume endometrial foi de $3,48 \mathrm{~mL}$ (sensibilidade de $100 \%$ e especificidade de $68.2 \%$ ). A área sob a curva ROC foi significativamente mais alta $(\mathrm{p}=0,027)$ para o volume de endometrial. Nenhuma gravidez foi encontrada em mulheres que tiveram um volume de endometrial abaixo de $3,8 \mathrm{~mL}$ (15 pacientes) ou espessura abaixo de 7,9 $\mathrm{mm}$ (3 pacientes).

Conclusões: O volume e a espessura endometrial uma semana após a TE são significativamente maiores em mulheres grávidas, e esta diferença foi mais evidente para o volume de endometrial. É provável que esta diferença ocorra devido ao ingurgitamento endometrial que ocorre no período próximo à implantação.

\section{EFEITOS DA CINESIOTERAPIA NA FUNÇÃO MUSCULAR DO ASSOALHO PÉLVICO E NA QUALIDADE DE VIDA DE MULHERES COM INCONTINÊNCIA URINÁRIA DE ESFORÇO POR HIPERMOBILIDADE URETRAL}

Elaine Cristine Lemes Mateus de Vasconcelos
Orientador: Prof.Dr. Maurício M. Sabino de Freitas
Dissertação de Mestrado apresentada em 28/04/2006

Introdução: A cinesioterapia do assoalho pélvico constitui uma forma recomendada de tratamento conservador para a incontinência urinária, porém os seus efeitos na função muscular e na qualidade de vida não estão bem estabelecidos.

Objetivos: Avaliar o efeito da cinesioterapia na função muscular do assoalho pélvico, na qualidade de vida e na queixa clínica de mulheres com inconti- nência urinária de esforço por hipermobilidade uretral. Avaliar o grau de satisfação com o tratamento e verificar se a função muscular do assoalho pélvico influencia na qualidade de vida e no grau de satisfação com o tratamento.

Pacientes e Métodos: Vinte e cinco mulheres com idade entre 26 e 50 anos (média: 41,04 $\pm 5,85$ anos) e incontinência urinária de esforço por hipermobilidade uretral foram submetidas à cinesioterapia do assoalho pélvico por um período de seis meses. Utilizamos a avaliação funcional do assoalho pélvico por meio da palpação digital transvaginal e do peri- 
neômetro digital, e o questionário de qualidade de vida "Incontinence Quality of Life (I-QOL)" para avaliar o efeito do tratamento na qualidade de vida das mulheres estudadas. As avaliações foram feitas no início, e após três e seis meses de tratamento. A melhora clínica e o grau de satisfação com o tratamento foram avaliados subjetivamente.

Resultados: Na avaliação funcional do assoalho pélvico pela palpação digital, as médias de contração foram 3,12 $\pm 1,05$ graus na avaliação inicial, $3,84 \pm 1,03$ graus na avaliação de 3 meses e $3,80 \pm 1,12$ graus na avaliação de 6 meses; e na avaliação com o perineômetro, as médias de contração foram $21,88 \pm$ 14,39 Sauers na avaliação inicial, 27,88 $\pm 15,11$ Sauers na avaliação de 3 meses e 28,52 $\pm 14,36$ Sauers na avaliação de 6 meses. Na avaliação da qualidade de vida, as médias do escore total foram $55,82 \pm 23,78$ na avaliação inicial, 73,77 $\pm 26,25$ na avaliação de 3 meses e $80,59 \pm 27,75$ na avaliação de 6 meses. Tanto na análise da função muscular do assoalho pélvico como do escore total de qualidade de vida, houve um aumento estatisticamente significativo entre a avaliação inicial e a avaliação de 3 meses, e entre a avaliação inicial e a avaliação de 6 meses. Entretanto, não observamos uma diferença significativa entre as avaliações de $3 \mathrm{e}$ 6 meses. A cura ou melhora subjetiva da sintomatologia associada à satisfação com o tratamento foi constatada em $72 \%$ das mulheres na avaliação de 3 meses e em $76 \%$ na avaliação de 6 meses, não sendo encontrada diferença estatisticamente significativa entre estas duas avaliações. A função muscular do assoalho pélvico influenciou na qualidade de vida e no grau de satisfação com o tratamento.

Conclusão: A cinesioterapia melhora a função muscular do assoalho pélvico, a qualidade de vida e a queixa clínica de mulheres com incontinência urinária de esforço por hipermobilidade uretral, com conseqüente elevada satisfação com o tratamento. O período de três meses parece suficiente para a obtenção de boa resposta terapêutica.

\section{IMUNOLOGIA BÁSICA E APLICADA}

\section{GRANULOMA PARACOCCIDIOIDOMICÓTICO : IMUNIDADE PROTETORA DEPENDE DA INTERAÇÃO ENTRE RESPOSTAS CELULAR E HUMORAL NA INFECÇÃO POR Paracoccidioides brasiliensis}

\section{Luciano Aparecido Panagio}

Orientador: Prof. Dr. João Santana da Silva

Tese de Doutorado apresentada em 28/04/2006

A resposta do tipo Th1 e a formação de granulomas são fundamentais na proteção contra $P$. brasiliensis, fungo causador da paracoccidioidomicose (PCM). A citocina de maior relevância durante a PCM é o INF- $\gamma$, responsável pelo aumento da produção de óxido nítrico pelos macrófagos. Durante a PCM a produção de IFN- $\gamma$ depende principalmente de IL-12, estruturalmente semelhante à IL-18, que induz IFN- $\gamma$ em algumas doenças infecciosas. Nossos estudos demonstraram que IL-18 não é essencial para proteção na PCM sistêmica e nem para indução de FasL. A expressão de Fas/FasL em linfócitos pulmonares aumen- tou durante a PCM, mas de maneira semelhante entre animais deficientes de IL-18 e animais selvagens. Inesperadamente, animais defectivos do receptor Fas (lpr) infectados por $P$. brasiliensis apresentaram carga fúngica maior que animais selvagens (WT). Pensávamos que a taxa de apoptose de leucócitos seria menor em lpr, o que seria favorável à eliminação do fungo. Analisamos a composição do infiltrado inflamatório na PCM e observamos similaridade entre lpr e WT. Avaliamos a migração de leucócitos em reposta a estímulo por tioglicolato e verificamos uma igual migração entre lpr e WT, mas leucócitos de animais lpr apresentam menor aderência ao endotélio. Houve maior produção das quimiocinas KC e MIP- $1 \alpha$ em pulmões de animais lpr infectados, que pode ter contribuído para migração de neutrófilos em lpr. Verificamos produção 
semelhante de mieloperoxidase por neutrófilos pulmonares, óxido nítrico e IFN- $\gamma$ em animais WT e lpr infectados por $P$. brasiliensis. Surpreendentemente, encontramos maior número de células pulmonares apoptóticas em animais lpr infectados por P. brasiliensis, a despeito da menor expressão de Fas nessas células, significando que $P$. brasiliensis pode induzir apoptose por diferentes vias. Encontramos diminuição de linfócitos B em animais lpr durante PCM, que poderia contribuir para maior susceptibilidade de lpr. Descobrimos que animais deficientes de linfócitos B são mais susceptíveis ao P. brasiliensis, mostrando que essas células participam ativamente da proteção na PCM.
A transferência de soro imune para animais deficientes de linfócitos B protegeu parcialmente contra $P$. brasiliensis, o que nos permite sugerir que tanto a presença de células B quanto de anticorpos é fundamental na defesa contra o P. brasiliensis. Nossos resultados nos permitem afirmar que na PCM sistêmica murina IL-18 não é essencial, suscitando cautela na utilização de IL-18 como adjuvante terapêutico nessa micose. A via de sinalização Fas/FasL é importante na resistência contra $P$. brasiliensis, através de mecanismo independente de indução de apoptose e de alterações funcionais de neutrófilos, mas possivelmente ligado à resposta de linfócitos $\mathrm{B}$.

\section{BIODISTRIBUIÇÃO DAS MICROESFERAS DE PLGA (CO-POLÍMERO DERIVADO DOS ÁCIDOS LÁTICO E GLICÓLICO) CARREANDO O PLASMÍDEO pCDNA Hsp65, E DETERMINAÇÃO DO TRÁFEGO INTRACELULAR DESSA FORMULA- ÇÃO E DO PLASMÍDEO: INFLUÊNCIA NA INDUÇÃO DA RESPOSTA IMUNE}

\author{
Ana Paula Fávaro Trombone \\ Orientadora:Profa.Dra. Arlete A.M. Coelho-Castelo \\ Tese de Doutorado apresentada em 02/05/2006
}

Os dados apresentados neste trabalho demonstraram que as microesferas, utilizadas como veiculo para imunização com DNA-Hsp65/DMT, foram amplamente distribuídas pelo organismo após a administração intramuscular. Essas partículas, em geral, foram capturadas por células apresentadoras de antígenos, como macrófagos e células dendríticas através de fagocitose. Além disso, os resultados demonstraram que as células dos linfonodos drenantes provenientes de animais que receberam a formulação contendo DNA-Hsp65/DMT apresentaram aumento significativo na expressão de moléculas superficiais CD80, CD86 e MHC de classe II, quando comparadas com as formulações controle (vetor/DMT e vazia). Em relação ao tráfego intracelular, as microesferas permaneceram nos endossomos tardios e/ou lisossomos por até 15 dias, sugerindo que essas construções foram hidrolisadas nessas vesículas para liberação do DNA, não ocorrendo assim escape da formulação para o compartimento citoplasmático.

Por outro lado, os resultados apresentados sobre o tráfego intracelular do DNA plasmideal demons- traram que o DNA (DNA-Hsp65) foi capturado por células dendríticas e macrófagos da linhagem J774 pelos processos de macropinocitose e endocitose mediada por clatrina, respectivamente. Após a captura, o DNA plasmideal localizou-se nos endossomos tardios e/ou lisossomos sendo capaz de inibir a acidificação das mesmas, provavelmente como mecanismo de escape da degradação enzimática. Além disso, não houve co-localizaçao do DNA com Rab5 e Lamp I, sugerindo que a inibição da acidificação pode ter interferido com o recrutamento desses marcadores. Adicionalmente, a alteração da acidificação dessas vesículas inibiu a apresentação do antígeno KLH pela via de classe II, quando as células foram previamente tratadas com DNA plasmideal, porém, não alterou o recrutamento de MyD88 para as vesículas. A cinética do tráfego intracelular do DNA nu sugere que o DNA plasmideal permaneça em vesículas até alcançar a região perinuclear. Assim sendo, os resultados apresentados neste trabalho sobre a biodistribuição e tráfego intracelular das microesferas, e, principalmente, do DNA plasmideal, trazem novas contribuições para os esclarecimentos dos mecanismos de ativação celular em vacinas de DNA. Além disso, abrem perspectivas para o uso de DNA no controle de células do sistema imune e terapia gênica. 


\section{ANÁlISE dA CINÉTICA DE EXPRESSÃO DE GENES PARA CITOCINAS, QUI- MIOCINAS E SEUS RECEPTORES, MOLÉCULAS DE ADESÃO E FATOR DE TRANSCRIÇÃO NA PELE E LINFONODOS DE CAMUNDONGOS INFESTADOS POR CARRAPATOS}

\section{Cláudia Espósito Passoni}

Orientadora: Profa.Dra. Beatriz Rossetti Ferreira

Dissertação de Mestrado apresentada em 02/05/2006

Carrapatos são artrópodes hematófagos de grande importância médica e veterinária devido aos efeitos deletérios diretos por eles causados ao se fixarem e sugarem seus hospedeiros, além de serem importantes vetores de microorganismos patogênicos. Durante o processo de repasto, carrapatos estimulam a resposta imune e inflamatória dos hospedeiros. No entanto, são capazes de suprimir elementos da imunidade natural e adquirida através de fatores presentes na saliva inoculada durante o repasto. No atual estudo realizou-se análise da cinética de expressão de genes de citocinas, quimiocinas e seus receptores, moléculas de adesão e fator de sinalização intracelulares relacionados à resposta imune /inflamatória induzida na pele e linfonodos de camundongos durante infestações com carrapatos Rhipicephalus sanguineus. Após sucessivas infestações, a saliva dos carrapatos foi capaz de modular a resposta imune do hospedeiro para o padrão Th2, induzindo aumento na expressão de IL-4 na pele em 35 vezes e de 6,2 vezes nos linfonodos. Adicionalmente observou-se a inibição da expressão de IFN- $\gamma$ e IL-12 na pele (em 28 e 93 vezes respectivamente) no terceiro dia de infestação. Foi também observada inibição da expressão do gene de CCR4, importante receptor responsável pela migração de células T para a pele, enquanto outras moléculas como ICAM-1 e LFA-1, relacionadas à adesão celular, não apresentaram expressão alterada. Por outro lado, o hospedeiro foi capaz de responder ao estímulo do parasita induzindo o aumento de mensagem para as quimiocinas MIP-1 $\alpha$ e MIP-1 $\beta$, produção esta confirmada pela detecção destas quimiocinas na pele por imunoistoquímica. MIP- $1 \alpha$ e MIP- $1 \beta$ exercem função quimioatraente para as células CD11b+ (macrófagos e neutrófilos), presentes no sítio de fixação dos carrapatos. Os resultados obtidos neste estudo permitem uma melhor compreensão da interação parasitahospedeiro e dos fatores que garantem ao parasita o controle da resposta imunológica do hospedeiro, a fim de favorecer a sua sobrevivência.

\section{SALIVA DE CARRAPATOS RHIPICEPHALUS SANGUINEUS (LATREILLE, 1806) MODULA A MIGRAÇÃO E FUNÇÃO DE CÉLULAS DENDRÍTICAS}

\section{Carlo José Freire de Oliveira}

Orientadora: Profa. Dra. Beatriz Rossetti Ferreira

Dissertação de Mestrado apresentada em 15/05/2006

Carrapatos são artrópodes hematófagos parasitas de vertebrados que causam inúmeros prejuízos aos animais domésticos, silvestres e ao homem, resultado da espoliação direta e da transmissão de doenças. Diversos trabalhos vêm mostrando que substâncias ativas presentes na saliva de carrapatos modulam a atividade de células e/ou moléculas relacionadas com a resposta imune. Um exemplo seria uma proteína isolada da saliva de algumas espécies de carrapatos com atividade anti-IL-8 humana. Uma das células críticas envolvidas na modulação e indução de resposta imune a diversos patógenos é a célula dendrítica (CDs). Estudos prévios do nosso grupo demonstram que a saliva de carrapatos $R$ sanguineus inibe a diferenciação e maturação de CDs de camundongos. Assim, o presente trabalho procurou elucidar o efeito da saliva de carrapatos na migração e função de CDs (CD11c+) diferenciadas na presença de GM-CSF e IL-4 a partir de células da medula óssea. A saliva inibiu mais de $50 \%$ a função quimiotática de MIP- $1 \alpha$ para CDs, mas não a de RANTES, MIP-1 $\beta$, SDF-1 $\alpha$ e MCP-1. Também verificou-se que CDs pré-incubadas com saliva por 24 ou 48 h reduziram em cerca de $60 \%$ a migração induzida por quimiocinas associadas com a migração de CDs imaturas (MIP-1 $\alpha$ e RANTES). Por outro lado, a saliva não alterou a migração de $\mathrm{CDs}$ amadurecidas com lipopolissacarídio (LPS) em direção a MIP-3 $\beta$, uma quimiocina relevante na indução de migração de CDs maduras. A redução da migração de CDs imaturas devido à ação da saliva pode resultar num menor repovoamento de CDs no sítio de fixação dos carrapatos, processo essencial para a vi- 
gilância imune nos tecidos periféricos. Nos ensaios de migração in vivo, a inoculação de saliva de carrapatos na pele em conjunto com aplicação tópica de isotiocianato de fluoresceína (FITC) não alterou a migração de CDs CD11c+FITC+ da pele para os linfonodos drenantes. Esses achados corroboram nossos resultados in vitro, indicando que a saliva não altera a migração de CDs maduras e sustentam a teoria que apenas CDs com fenótipo maduro migram para os órgãos linfóides secundários. Procurando avaliar o efeito da saliva sobre a capacidade das CDs sensibilizarem células $\mathrm{T}$ naive in vivo, $\mathrm{CDs} \mathrm{CD} 11 \mathrm{c}+$ foram incubadas com saliva, pulsadas com hemocianina (KLH) e inoculadas em camundongos, sendo estes sacrificados após 5-6 dias para avaliação da ativação imune específica das células dos linfonodos. Os resultados mostraram que apesar da saliva não inibir as CDs a induzirem uma proliferação de células T específicas ao antígeno KLH (sensibilização de células T naive), a produção de IFN- $\gamma$ e TGF- $\beta$ por essas células foi praticamente extinguida, enquanto que a sínte- se de IL-10 mostrou-se significativamente menor que a observada para camundongos que receberam CDs pulsadas com KLH sem saliva. Linfócitos com estas características podem ser enquadrados num estágio semelhante ao de energia celular, uma vez que a estimulação antigênica específica dos linfócitos T naive não induziu diferenciação destes num padrão Th1 ou $\mathrm{Th} 2$ de resposta imune. Finalmente, ao se caracterizar o fenótipo das CDs pulsadas com KLH na presença de saliva verificou-se uma reduzida expressão das moléculas CD80 e CD86, embora a expressão de MHCII, CD54 e CD40 tenham se mostrado similar às CDs pulsadas apenas com KLH. A deficiência da expressão de CD80 e CD86 em CDs pode levar a indução de células $\mathrm{T}$ anérgicas, hipótese anteriormente sugerida para explicar os resultados encontrados nos ensaios de apresentação de antígenos. Tomados em conjunto, os achados destacam um novo mecanismo pelo qual a saliva de carrapatos possa estar comprometendo a montagem da resposta imune adquirida a carrapatos e/ou a patógenos por eles transmitidos.

\section{FATORES DETERMINANTES DA RESISTENACIA DISTINTA DE MACHOS E FÊMEAS À INFECÇÃO EXPERIMENTAL POR Paracoccidioides brasiliensis}

\section{Camila Figueiredo Pinzan}

Orientadora:Profa.Dra. Maria Cristina R. A. Barreira Dissertação de Mestrado apresentada em 17/05/2006

Paracoccidioides brasiliensis (P. brasiliensis) é o agente causador da paracoccidioidomicose, micose sistêmica endêmica na América Latina, caracterizada por uma desigual distribuição entre os sexos. Homens manifestam mais a doença clínica do que mulheres, sugerindo que fatores hormonais têm importante papel na patogênese da doença (RESTREPO et al., 1984).

Paracoccina é uma lectina isolada a partir de preparação de exoantígenos de P. brasiliensis avaliada em nosso laboratório como possível fator de virulência do fungo. A proposta do presente estudo foi comparar a resposta imunitária de camundongos machos e fêmeas à infecção por P. brasiliensis, enfatizando o papel exercido por paracoccina nas eventuais diferenças observadas.

Avaliamos o perfil de citocinas e óxido nítrico produzidos pelos grupos de camundongos machos e fêmeas infectados experimentalmente por $P$. brasiliensis. O estímulo in vitro com paracoccina de célu- las de camundongos fêmeas infectados resultou em maior produção de citocinas que caracterizam o padrão Th1 de resposta (protetor contra a infecção) e óxido nítrico (dotado de atividade fungicida), enquanto células de machos produziram IL-10 (citocina de padrão Th2) em concentrações muito superiores às produzidas por fêmeas.

A avaliação da proliferação de células esplênicas de camundongos machos e fêmeas infectados mostrou que a supressão da resposta proliferativa de células esplênicas, característica da infecção por $P$. brasiliensis, foi mais prolongada em machos.

Macrófagos ativados são essenciais na defesa contra a infecção por $P$. brasiliensis, razão pela qual avaliamos a capacidade fagocítica e microbicida de macrófagos de camundongos de ambos os sexos. Macrófagos de camundongos machos e fêmeas são dotados de capacidade fagocítica similar, mas diferiram quanto à capacidade microbicida, mais acentuada em fêmeas, fato presumivelmente associado a maior produção de óxido nítrico por seus macrófagos.

O papel de hormônios sexuais nos fenômenos observados foi avaliado utilizando- se procedimentos de gonadectomia e reposição hormonal inversa. Célu- 
las de machos castrados tratados com estradiol passaram a produzir elevadas concentrações de IFN\&\#61543; e reduziram a produção de IL-10 em resposta ao estímulo com paracoccina. Fêmeas castradas tratadas com testosterona mostraram resposta antagônica, com aumento na produção de IL-10 e diminuição de IFN-\&\#61543. Esses dados comprovam que o microambiente hormonal exerce influência na produção de citocinas por células de animais infectados por P. brasiliensis, o que sabidamente pode levar ao aumento ou a diminuição na susceptibilidade à infecção.

Nossos resultados demonstram haver claras diferenças entre as respostas imunitárias de machos e fêmeas na paracoccidiodomicose experimental e revelam o primordial papel desempenhado pelos hormônios sexuais. Sugerem ainda que antígenos fúngicos, como a paracoccina, possam interferir na determinação de respostas imunitárias distintas de machos e fêmeas infectados com P.brasiliensis.

\section{AVALIAÇÃO DA RECONSTITUIÇÃO IMUNOLÓGICA EM PACIENTES COM DIABETE MELITO DO TIPO 1 E ESCLEROSE MÚLTIPLA APÓS TRANS- PLANTE AUTÓlOGO DE CÉlULAS TRONCO HEMATOPOÉTICAS}

\author{
Kelen Cristina Ribeiro Malmegrim de Farias \\ Orientador: Prof. Dr. Júlio César Voltarelli \\ Tese de Doutorado apresentada em 17/05/2006
}

Ensaios clínicos têm demonstrado que a imunoablação seguida de transplante autólogo de células tronco hematopoéticas (TACTH) é capaz de suprimir a atividade inflamatória em pacientes com doenças auto-imunes (DAIs) e pode induzir remissões clínicas prolongadas nesses pacientes, mas o mecanismo de ação do TACTH ainda não é bem esclarecido. $\mathrm{O}$ racional do TACTH em DAIs baseia-se na idéia de que a imunoablação intensa possa eliminar as células autoreativas e que o novo sistema imune reconstituído dos precursores hematopoéticos possa restabelecer tolerância. O objetivo deste trabalho foi avaliar a reconstituição imunológica em pacientes com diabete melito tipo $1(\mathrm{DM}, \mathrm{N}=11)$ e pacientes com esclerose múltipla (EM, N=18), seqüiencialmente após o TACTH. A reconstituição imunológica observada nos pacientes com DM (um ano de seguimento pós-transplante) e nos pacientes com EM (dois anos de seguimento pós-transplante), foi caracterizada por mecanismos periféricos timo-independentes. Após o transplante, houve uma predominância de células $\mathrm{T}$ de memória central, memória efetora e também de células $\mathrm{T}$ efetoras diferenciadas, principalmente de linfócitos T CD8+. Essas células provavelmente se originam da expansão homeostática periférica de linfócitos $\mathrm{T}$ de memória residuais que sobreviveram ao regime de condicionamento ou foram re-infundidos com as células tronco no momento do transplante. Os números de linfócitos $\mathrm{T} \mathrm{CD}^{+}{ }^{+}$e $\mathrm{CD}^{+}$naive, incluindo as células $\mathrm{T}$
$\mathrm{CD} 4{ }^{+} \mathrm{CD} 45 \mathrm{RA}^{+} \mathrm{CD} 31^{+}$recém-imigrantes do timo, não recuperaram os níveis basais durante o período póstransplante analisado. Após o TACTH, houve uma predominância de células $\mathrm{T} \mathrm{CD} 4^{+}$e $\mathrm{CD} 8^{+}$produtoras de citocinas do padrão $T_{H} 1$ (INF- $\gamma$ e TNF- $\alpha$ ). Por outro lado, foi observado um aumento da porcentagem de células $\mathrm{T} \mathrm{CD}^{+}$e $\mathrm{CD} 8^{+}$produtoras de citocinas do padrão $\mathrm{T}_{\mathrm{H}} 2$ (IL-4, IL-5 e IL-10) no pré-condicionamento e em alguns períodos após o TACTH. Análises espectrais do repertório da cadeia $\mathrm{V} \beta$ dos receptores de células T (TCRs), por TCRBV CDR3 spectratyping, identificaram quatro padrões básicos de reconstituição do repertório. O padrão que consistiu na reconstituição da diversidade a partir de um repertório pré-transplante diverso, foi o mais dominante em todos os pacientes analisados. Para algumas famílias $\mathrm{V} \beta$ foi observado um padrão de reconstituição que consistiu na recuperação da diversidade a partir de um repertório pré-transplante restrito, o que sugere um aumento da diversidade do repertório de células $\mathrm{T}$ após o transplante. Foram observadas mudanças na composição do repertório de células $\mathrm{T}$ após o TACTH, evidenciadas por alterações qualitativas e quantitativas dos picos de CDR3 das famílias V $\beta$, que poderiam explicar a indução da remissão da doença auto-imune observada na maioria dos pacientes. Foi observada uma rápida reconstituição de células $\mathrm{T}$ $\mathrm{CD} 4^{+} \mathrm{CD} 25^{\text {high }}$ e um aumento na expressão do gene Foxp3, marcador molecular específico para células $\mathrm{T}$ reguladoras $\mathrm{CD} 4{ }^{+} \mathrm{CD} 25^{\text {high }}$, na maioria dos pacientes avaliados. Esses resultados sugerem uma melhora de mecanismos reguladores que podem contribuir para o restabelecimento da tolerância imunológica nos pacientes com DM e EM submetidos ao TACTH. 


\section{MODULAÇÃO DA RESPOSTA IMUNE PELA SALIVA DE CARRAPATOS Rhipicephalus sanguineus: ESTUDO DO ENVOLVIMENTO DE CÉLULAS T REGULATÓRIAS}

\author{
Daniela Dantas Moré \\ Orientadora: Profa.Dra. Beatriz Rossetti Ferreira \\ Dissertação de Mestrado apresentada em 22/05/2006
}

Carrapatos são artrópodes hematófagos de distribuição cosmopolita que têm grande importância médica e veterinária devido ao efeito deletério direto causado por se fixarem e sugarem seus hospedeiros, como também por serem importantes vetores de doenças para o homem e para os animais domésticos. Sabendo que carrapatos permanecem fixos em seus hospedeiros por longos períodos de tempo sem serem rejeitados, é possível inferir que esses ácaros possuam um arsenal de mecanismos que atuem no controle da resposta imune do hospedeiro. De fato, diversos trabalhos têm demonstrado que carrapatos são capazes de modular a resposta imune de seus hospedeiros através de componentes presentes na saliva, que são inoculados durante o repasto sangüíneo. Assim, este trabalho procurou investigar se carrapatos exercem a modulação da resposta imune do hospedeiro através do recrutamento de células $\mathrm{T}$ regulatórias CD4+ CD25+ (Tregs), com a intenção de conter uma resposta inflamatória / imune prejudicial à sua alimentação. Para isso, células isoladas de amostras de pele e linfonodos de camundongos BALB/c infestados com carrapatos Rhipicephalus sanguineus foram analisadas quanto à expressão das moléculas de superfície CD4, CD25, CTLA-4, CD45RB, GITR e CD103 (fe- nótipo de células Tregs), por citometria de fluxo. Adicionalmente, as células obtidas dos linfonodos foram avaliadas quanto à expressão de mensagem para o fator de transcrição Foxp3 (característico da função regulatória), por PCR quantitativo. Paralelamente, saliva de R. sanguineus foi inoculada na orelha de animais da mesma linhagem, a fim de se comparar o infiltrado celular com o obtido na pele dos camundongos infestados com carrapatos. Os resultados mostraram que as infestações não alteraram a percentagem de células T CD4+CD25+ nem a expressão de moléculas associadas ao fenótipo de células Tregs nas células infiltradas na lesão de fixação dos carrapatos ou nos linfonodos comparação a camundongos controles. Também não se verificou aumento da expressão do gene para Foxp3 nos linfonodos em nenhum dos grupos analisados. Por outro lado, a inoculação de saliva na orelha de camundongos induziu um aumento significativo da população de células T CD4 +, porém estas também não apresentavam fenótipo regulatório, sugerindo que o mecanismo de imunomodulação exercido pelos carrapatos sobre seus hospedeiros não é mediado por essas células. Resultados adicionais mostraram que a saliva de carrapatos reduziu significativamente a percentagem de células dendríticas nas orelhas dos camundongos, sugerindo que carrapatos podem estar modulando a resposta imune de seus hospedeiros por diminuírem o repovoamento da pele com células dendríticas, as quais são essenciais na vigilância imune dos tecidos periféricos.

\section{PARTICIPAÇÃO DAS METALOPROTEASES MMP-2 E MMP-9 NA PATOGÊNE- SE DA MIOCARDITE DURANTE A FASE AGUDA DA INFECÇÃO POR Trypano- soma cruzi}

\section{Fredy Roberto Salazar Gutierrez}

Orientador: Prof.Dr. João Santana da Silva

Dissertação de Mestrado apresentada em 22/05/2006

Durante a infecção por Trypanosoma cruzi, uma forte resposta inflamatória ocorre no miocárdio. Tal processo é parcialmente modulado por citocinas e quimiocinas produzidas pelos leucócitos e cardiomiócitos. Recentemente, as metaloproteases da matriz (MMP) têm sido encontradas como novos moduladores da inflamação em vários modelos. Para investigar in vivo a participação da MMP-2 e MMP-9 na miocardite experimental induzida por T. cruzi, nós realizamos ensaios de imunohistoquímica, zimografia em ge- 
latina, ELISA e PCR em tempo real para MMP-2 e MMP-9 no tecido cardíaco de camundongas C57BL/ 6 fêmeas infectadas ou não com 1000 formas tripomastigotas de T. cruzi (cepa Y). Adicionalmente, um grupo de animais foi tratado com doxiciclina, na dose de $30 \mathrm{mg} / \mathrm{kg} /$ day V.O. (uma dose que sabidamente inibe as MMP) na água de beber, e o grupo controle recebeu o mesmo volume de água. Foi detectado um aumento da imunoreatividade para MMP-2 e MMP-9, e da atividade enzimática de MMP-9 no tecido cardíaco de camundongos por volta das 2 semanas de infecção, comparado aos camundongos não infectados. Foi detectado também um aumento de mRNA para a pro-
MMP9 nos dias 14 e 20 da infecção, coincidindo com a fase mais intensa da miocardite. Quando tratados com o inibidor de MMPs, os animais apresentaram um leve retardo no pico da parasitemia, melhora na sobrevivência, e redução no índice inflamatório no coração, comparados ao grupo controle. Níveis reduzidos de NO sérico, e de TNF- $\alpha$ e INF- $\gamma$ no coração, foram também detectados. Esses resultados indicam um papel determinante para as MMP na patologia da miocardite chagásica, sugirindo novas opções terapêuticas. No entanto, são necessários estudos adicionais sobre a regulação de MMPs por moléculas do sistema immune e/ou do parasito durante esta infecção.

\section{PARTICIPAÇÃO DE CÉlULAS T REGULADORAS NO CONTROLE DA RESPOS- TA IMUNE DURANTE A PARACOCCIDIOIDOMICOSE HUMANA}

\author{
Karen Angélica Cavassani de Souza \\ Orientador: Prof.Dr. João Santana Silva \\ Tese de Doutorado apresentada em 26/05/2006
}

Assim como em diversas infecções de caráter crônico, na paracoccidioidomicose (PCM) há uma dinâmica interação entre parasita e hospedeiro. Estudos pertinentes demonstram claramente a participação de células $\mathrm{T}$ reguladoras $\mathrm{CD} 4+\mathrm{CD} 25+$ naturais (Tregs) no controle das respostas imunes a diversos patógenos, contribuindo para a persistência dos mesmos e o estabelecimento da infecção crônica. É sabido que as Tregs suprimem a proliferação de células $\mathrm{T}$ efetoras, utilizam a IL-2 produzida, produzem citocinas tais como TGF- $\beta$ e IL-10 e expressam de maneira constitutiva CTLA-4. De forma interessante, tais fenômenos podem ser observados nos leucócitos de pacientes com PCM. Assim, nós investigamos o possível envolvimento dessa população celular no controle da resposta imune no sangue periférico e nas lesões cutâneas e de mucosa mediadas por P. Brasiliensis durante a PCM. Não observamos diferenças na frequiência de leucócitos no sangue periférico de pacientes com PCM e indivíduos controles, exceto na população de células dendríticas CD11 c+CD1a+ (7,2 e $1,8 \%$, respectivamente). No entanto, uma maior percentagem de células T CD4+CD25+ co-expressando CTLA-4, GITR, TGF- $\beta$ de membrana ou Foxp3 com forte atividade supressora foi observada nos pacientes quando comparada às células de indivíduos controles $(94.0$ x $67.5 \%$, da inibição da resposta proliferativa de células $\mathrm{T}$ alogeneicas). Adicionalmente, nossos resultados mostraram que células T CD4+CD25+ co-expressando marcadores fenotípicos, CTLA-4, GITR, CD103, CD45RO, TGF- $\beta$ de superfície, Foxp3 e receptores de quimiocinas, CCR4 e CCRS, acumulam-se nas lesões. De fato, a expressão de CCL17 e CCL22, ambos associados com a migração de Tregs para os sítios periféricos, foi detectada nas biópsias cutâneas dos pacientes. Além disso, 78\% das células T CD4+CD25+ derivadas das lesões foram TGF- $\beta+$. Na proporção 1:10, as células T CD4+CD25+ isoladas das lesões de cinco dos oito pacientes analisados foram capazes de suprimir a resposta proliferativa de células T alogeneicas mediada por PHA (a percentagem de inibição variou de 51 a $81 \%$ ) e essas lesões apresentaram granulomas compactos e organizados. De forma contrária, as células T CD4+CD25+ incapazes de inibir a resposta proliferativa foram isoladas de pacientes cujas lesões apresentaram um processo granulomatoso que condiz com a forma aguda e subaguda da PCM. Em conjunto, os dados apresentados neste estudo revelam a presença de Tregs em pacientes infectados por P. brasiliensis, contribuindo para uma melhor compreensão dos fatores que modulam a resposta imune sistêmica e local durante a PCM humana. 


\section{ESTUDO DA REPLICAÇÃO DO VÍRUS DENGUE-2 SOB A AÇÃO DE DROGAS INIBIDORAS DO METABOLISMO CELULAR}

\section{Kleber Juvenal Silva Farias}

Orientador: Prof.Dr. Benedito A. Lopes da Fonseca

Tese de Doutorado apresentada em 26/05/2006

Os vírus dengue representam o mais importante arbovirus transmissor de doença em humanos, resultando em progressivas manifestações clínicas tais como febre da dengue, febre hemorrágica da dengue e síndrome do choque da dengue. $\mathrm{O}$ controle desta infecção é feito apenas pelo controle do vetor, pois não existe até o momento, nenhuma vacina que proteja os indivíduos desta infecção e nenhum antiviral para o controle da replicação viral. Na tentativa de se entender se poderia haver interferência de drogas na replicação do vírus dengue, células C6/36 e Vero foram cultivadas e as monocamadas confluentes foram infectadas com vírus dengue-2, a uma multiplicidade de infecção (MOI) de 0,1. Para confirmação da replicação viral, um ensaio de imunofluorescência indireta foi realizado sobre células infectadas. A análise da inibição da replicação viral pelas drogas que interferem na homeostase celular foi realizada em monocamadas de células Vero e C6/36 tratadas, concomitante e após a infecção viral, com cloroquina (aumenta o pH endossomal), brefeldina A (inibe o fluxo vesicular de proteínas) e citocalasina B (desestabiliza os filamentos de actina). Sobrenadantes de células infectadas foram coletados após períodos de $0,6,12,24,48,72,96,120$, 144 e 168 horas da infecção viral. Foi realizada a extração do RNA total do sobrenadante e a replicação viral foi analisada através da quantificação dos vírus produzidos pela detecção do número de cópias de RNA do vírus dengue-2. Esta quantificação foi realizada através da PCR em tempo real onde a região 3 ' não-codificadora do genoma dengue- 2 foi analisada utilizando primers específicos para o vírus dengue-2 e usandose o SYBR GREEN® One-Step RT-PCR Master Mix Reagents Kits (Applied Biosystems). Para verificar a ação das drogas in vivo no sentido de investigar o seu possível uso em humanos, grupos de cinco camundongos Swiss de 4 semanas de idade foram desafiados com uma injecção intracerebral de uma cepa virulenta do dengue-2, e tratados ou não 2 horas ou 3 dias após a infecção com as drogas por via intraperitoneal. A cloroquina foi administrada em intervalos de 24 horas durante sete dias, enquanto que a brefeldina A e a citocalasina $\mathrm{B}$ foram dose única. Os animais foram observados durante 21 dias. A porcentagem de sobrevivência no grupo de camundongos infectados com vírus e tratados com cloroquina 2 horas após infecção foi melhor do que nos outros grupos (tratadas ou com brefeldina A ou com citocalasina B ou cloroquina 3 dias após infecção) já que houve um desvio da curva de sobrevivência e um deles sobreviveu enquanto nos outros grupos, todos morreram. Todos os animais que não foram tratados morreram por volta do $10^{\circ}$ dia. A transcrição reversa por PCR em tempo real mostrou que, comparado as células controle, houve uma diminuição estatisticamente significante na replicação viral em células Vero quando tratadas com cloroquina, brefeldina A e citocalasina $\mathrm{B}$; resultados que foram confirmados por ensaio de placa (PFU). Em células C6/36, a cloroquina induziu um aumento estatisticamente significante na replicação viral a partir de 12 horas quando comparado as células controle, mostrando que este vírus usa uma via diferente de penetração nessas células onde o resultado foi confirmado por ensaio de placa (PFU). A cloroquina mostrou-se eficiente na inibição da replicação do vírus dengue- 2 in vivo (camundongos) 2 horas após infecção e in vitro (Vero), enquanto que com a brefeldina $\mathrm{A}$, citocalasina $\mathrm{B}$ e cloroquina 3 dias após infecção não tivemos resultados satisfatórios in vivo, porém in vitro essas drogas mostraram-se eficientes. Este trabalho mostra que algumas drogas poderão ter um papel importante no tratamento da dengue em um futuro próximo.

\section{MODULAÇÃO DA RESPOSTA IMUNE POR ANTÍGENOS ALIMENTARES: CA- RACTERIZAÇÃO DE UM NOVO MODELO DE INFLAMAÇÃO INTESTINAL CRÔNICA}

Cristina Ribeiro de Barros Cardoso

Orientador: Prof. Dr. João Santana da Silva

Tese de Doutorado apresentada em 23/06/2006
Os processos inflamatórios intestinais envolvem diversas patologias associadas ao trato gastrointestinal (TGI), como a alergia alimentar, a doença de Crohn 
e colite ulcerativa. A utilização de modelos animais como fonte de estudo dessas doenças inflamatórias de mucosa tem sido relatada há vários anos; no entanto, em tais modelos, tanto as vias de administração, como as substâncias utilizadas para indução da inflamação, não reproduzem de maneira ideal a indução da doença que pode ocorrer no homem após a quebra da homeostasia de mucosa por antígenos alimentares. Deste modo, desenvolvemos um novo modelo de inflamação intestinal induzida por amendoim, alimento comumente presente na alimentação, altamente alergênico e já relatado como provável causa de alergia inflamatória, reproduzindo dessa forma, com mais fidelidade, o quadro patológico que ocorre no homem. Neste modelo, observamos que após as imunizações e ingestão contínua das sementes de amendoim, os camundongos perderam peso e desenvolveram inflamação intestinal crônica evidente, localizada principalmente no intestino delgado. Esta inflamação foi caracterizada por aumento do infiltrado inflamatório de células $\mathrm{CD}^{+}$, células $\mathrm{NK}$, linfócitos $\mathrm{B}$, células dendríticas, eosinófilos e mastócitos, além de edema, congestão e alterações morfológicas nas vilosidades intestinais. Observou-se, ainda, aumento da produção das imunoglobulinas IgG1 e IgE em detrimento a IgG2a nos animais selvagens imunizados com as proteínas de amendoim, associado a um padrão de resposta imune com produção de RNAm para citocinas tipo Th2. Em contrapartida, camundongos deficientes de IL-4 ganharam peso e demonstraram ausência de inflamação intestinal possivelmente devida à diminuição de produção de anticorpos tipo Th2 juntamente à menor ex- pressão de TNF- $\alpha$ e maior produção de transcritos para citocinas reguladoras e IFN- $\gamma$, na suposta tentativa de modulação do perfil de resposta Th2 patológico que é induzido nos animais selvagens. Nesse sentido, observamos também a diminuição do processo inflamatório intestinal nos animais B KO, demonstrando novamente que a inflamação em questão é mediada, em parte pela produção de anticorpos IgG1 e IgE específicos a amendoim. Além disso, houve diminuição de expressão das citocinas IL-4 e TNF- $\alpha$ e aumento de IL-12, IFN- $\gamma$ e IL-10 nesses animais quando comparados aos WT. Surpreendentemente, camundongos IFN- $\gamma$ KO ou IL-10 KO também apresentaram lesões intestinais menos evidentes, sugerindo mais uma vez o relevante papel das citocinas TNF- $\alpha$ e IL-4, diminuídas nesses animais em relação camundongos WT imunizados e desafiados. A produção de imunoglobulinas nesses camundongos, principalmente IFN- $\gamma$ $\mathrm{KO}$, foi similar aos selvagens. Dessa forma, concluímos que a inflamação intestinal observada é mediada por mecanismos alérgicos Th2 altamente dependentes da produção de anticorpos "patogênicos" alérgeno-específicos, como na alergia alimentar, com a participação evidenciada de eosinófilos, mastócitos e linfócitos B, além de plasmócitos. Finalmente, foi estabelecido um novo modelo animal para estudo, entendimento e desenvolvimento de novas terapias para processos inflamatórios intestinais, principalmente aqueles onde há o envolvimento de antígenos alimentares no desequilíbrio da homeostasia do sistema imune de mucosa, como em várias doenças humanas do sistema gastrintestinal.

\section{EXPRESSÃO DE FRAGMENTOS DE ANTICORPOS HUMANOS RECOMBINAN- TES CAPAZES DE INIBIR A ATIVIDADE FOSFOLIPÁSICA E DE INFLUENCIAR ATIVIDADES FARMACOLÓGICAS DO VENENO DE Crotalus durissus terrificus}

\section{Juliana Garcia de Oliveira}

Orientador: Prof.Dr. José Elpidio Barbosa

Dissertação de Mestrado apresentada em 28/06/2006

No Brasil são notificados cerca de 20.000 acidentes ofídicos anualmente ao Ministério da Saúde, sendo que as serpentes do gênero Crotalus são responsáveis por apenas $7 \%$ desses envenenamentos. Apesar da freqüência destes acidentes ser inferior à de acidentes com serpentes do gênero Bothrops, eles se tornam importantes não apenas pela alta incidência em certas regiões, mas por possuírem um potencial de produzir quadros clínicos graves, até mesmo fatais. No entanto, há mais de um século, a única terapia específica para envenenamento são os antivenenos constituídos de soro eqüino. Embora a imunoterapia tenha provado a sua eficácia na redução da mortalidade e morbidade em casos de picadas de serpentes, um dos maiores problemas no uso de soros hiperimunes de eqüinos como antivenenos, é que alguns indivíduos podem fi- 
car sensibilizados às proteínas de eqüinos. Portanto, têm-se buscado alternativas para a produção destes antivenenos, e uma delas é a produção de fragmentos de anticorpos humanos pela tecnologia de "phage display". Neste trabalho, buscou-se a produção de anticorpos monoclonais capazes de inibir a atividade fosfolipásica do veneno de Crotalus durissus terrificus, utilizando-se a biblioteca de fragmentos de anticorpos humanos (scFv) "Griffin.1", produzida no "Medical Research Council" - MRC, Cambridge, Reino Unido. O protocolo adotado para a seleção dos fagos-anticorpos contra o veneno bruto foi o de imobilização das proteínas em superfície sólida. Foi realizado um total de quatro turnos de seleção, sendo que os fagos-anticorpos selecionados foram analisados por ELISA para a escolha do turno com o maior título de fagos específicos para o veneno. O quarto turno de seleção foi escolhido para a produção de quatro placas de cultura de 96 poços de fagos-anticorpos monoclonais. Como o ELISA demonstrou que a maioria dos clones monoclonais foi capaz de reconhecer as proteínas do veneno, foi constituida uma placa com os clones mais positivos para a realização dos ensaios de inibição de hemólise. Dois clones produtores de fagos-anticorpos selecionados foram utilizados para a produção de frag- mentos de anticorpos solúveis. Dada a ausência de marcadores que facilitam a detecção destes anticorpos, a purificação total do scFv não foi obtida, optando-se por uma purificação parcial por gel filtração em resina Sephadex G-75. Após a obtenção de uma fração enriquecida de scFv, confirmou-se a capacidade de inibição da atividade enzimática por estes anticorpos. Resolveu-se, então, verificar a influência desta atividade em atividades farmacológicas causadas pelo veneno. Para isso, foram realizados ensaios de neutralização das atividades miotóxica, de indução de edema, anticoagulante e, por fim, da letalidade. Os ensaios de neutralização foram feitos com a subunidade CB da crotoxina, principal componente tóxico do veneno de Crotalus durissus terrificus, sendo responsável por $90 \%$ de sua toxicidade. Apenas no ensaio de letalidade testamos a atividade dos clones produtores de scFv contra crotoxina e veneno bruto. Os clones selecionados foram capazes de inibir parcialmente a atividade miotóxica e a indução de edema num período mais tardio, mas não tiveram nenhum efeito na atividade anticoagulante de CB. Nos ensaios de letalidade da crotoxina e do veneno bruto houve um aumento da sobrevida dos animais com os dois clones selecionados, sendo este aumento mais efetivo para a toxina isolada.

\section{NEUROLOGIA}

\section{DESENVOLVIMENTO DE SOFTWARE PARA PROCESSAMENTO DE IMAGENS QUANTITATIVAS EM RESSONÂNCIA MAGNÉTICA}

\section{Luciano Albuquerque Lima Saraiva}

Orientador: Prof. Dr. Antônio Carlos dos Santos

Dissertação de Mestrado apresentada em 19/05/2006

O uso de análise quantitativa em radiologia médica tem sido de grande valia na detecção de alterações não acessíveis à análise visual simples, dita qualitativa, seja por serem muito sutis, seja por não estarem presentes nas técnicas de imagem de ressonância magnética convencional. Porém, certos tipos de quantificação exigem a aquisição de softwares e de plataformas computacionais de alto custo, além de mão de obra especializada com conhecimento técnico em computação para operar em ambientes não intuitivos. Neste cenário o objetivo deste trabalho foi a implementação de um software para análise de transferência de magnetização em imagens de ressonância magnética nuclear que funcionasse na plataforma IBM$\mathrm{PC}$ e em sistemas operacionais livres como GNU/ Linux. Com este intuito foi elaborado um algoritmo para leitura de imagens codificadas no padrão DICOM 3.0, um algoritmo para a construção dos mapas de Razão de Transferência de Magnetização do volume adquirido e um visualizador com interface amigável para a segmentação e análise dos resultados. Ao fi- 
nal, software possibilitou a abertura da imagem DICOM. Também construiu de maneira eficiente, os mapas de diferença de porcentagem entre as imagens sem e com o pulso de transferência de magnetização (MTR), possibilitando, inclusive, correções de artefatos de movimentos, quando pouco intensos. Permitiu o delineamento de regiões de interesse irregular, com boa visibilidade dos resultados. Como controle padrão, os resultados foram comparados com o conjunto de ferramentas da Universidade McGill (Brain Imaging Center, McGuill University, Montreal, Quebec, Canadá), amplamente testado em artigos publicados.

\section{ESTUDO DE ASSOCIAÇÃO ENTRE O VOLUME CEREBELAR E A PRESENÇA DE ALELOS VARIANTES PARA O GENE QUE CODIFICA O PRÍON CELULÁR EM PACIENTES PORTADORES DE EPILEPSIA DE LOBO TEMPORAL MESIAL}

\section{Michelle Nave Valadão}

Orientador: Prof. Dr. Roger Walz

Dissertação de Mestrado apresentada em 23/05/2006

Objetivo: A atrofia do cerebelo tem sido observada em pacientes com epilepsias refratárias ao tratamento farmacológico. Recentemente demonstrou-se a associação entre a epilepsia do lobo temporal mesial associada à esclerose do hipocampo(ELTM-EH) e a presença de alelos variantes nos códons 129 e 171 do gene Prnp, que codifica a proteína prion celular $(\mathrm{PrPc})$ em pacientes brasileiros. Um estudo mostrou que a homozigose para a metionina no códon 129 do Prnp estava associada à redução no volume de substância branca e aumento no volume ventricular em voluntári- os saudáveis e pacientes com esquizofrenia.

Métodos: Nós investigamos a associação entre o genótipo do Prnp nos códons 129 e 171 do DNA obtido dos leucócitos de sangue periférico de 48 pacientes consecutivos com ELTM-EH e seus volumes normalizados do cerebelo.

Resultados: Após uma regressão múltipla para controlar o efeito de interações de variáveis clínicas, demográficas, eletrofisiológicas e o ajuste para múltiplas comparações, não se evidenciou associação entre o genótipo do Prnp nos códons 129 e 171 e o volume do cerebelo de pacientes com ELTM-EH.

Conclusão: A presença de alelos variantes do Prnp nos códons 129 e 171 não está associada ao volume do cerebelo em pacientes com o ELTM-EH.

\section{OFTALMOLOGIA}

\section{PREVALÊNCIA DAS AMETROPIAS NA CIDADE DE BORBA - AMAZONAS}

\section{Luciana Herculano Cattebeke}

Orientador: Prof. Dr. Antonio Augusto Velasco e Cruz Tese de Doutorado apresentada em 20/04/2006

Introdução: Este estudo foi feito para determinar a prevalência dos erros refrativos e doenças oculares em escolares de Borba, pequena cidade do Amazonas, Brasil, onde não existem informação sobre saúde ocular.

Métodos: Um total de 730 crianças, com 381 de sexo masculino e 349 do sexo feminino, da peque- na cidade de Borba, Amazonas, com idade média de 7 a 15 anos, de 4 escolas foram entrevistados com um protocolo ocular específico.

Os exames incluíram teste da acuidade visual e refração sob cicloplegia por auto-refrator, feita em todas as crianças. Também foi realizado exame ocular externo.

Os dados encontrados foram submetidos a análises estatísticas com teste de qui-quadrado, análise de variância unifatorial ANOVA) e teste de Tukey que permitiram o cálculo total da prevalência dos 
erros refrativos e a distribuição de acordo com idade e série.

Resultados: $\mathrm{O}$ astigmatismo foi o erro refrativo mais prevalente nas crianças examinadas $(3,9 \%)$. Na primeira série, $91,6 \%$ das crianças apresentaram astigmatismo, na segunda $89,9 \%$ e $3,85 \%$ na terceira.

A prevalência de miopia foi $0,5 \%$, valor significativamente baixo. A prevalência de hipermetropia também foi muito baixa $(0,6 \%)$.

Entre as 730 crianças somente 38 necessitaram correção óptica $(5,2 \%)$.

Pterígio foi encontrado em 3 crianças $(0,4 \%)$. Um caso de ptose foi detectado entre as crianças nesse estudo. Nenhuma criança foi considerada legal ou economicamente cega após a correção refrativa.

Conclusão: A prevalência de erros refrativos é muito baixa entre escolares da cidade de Borba. Em Borba, da primeira a terceira série, a refração ocular não foi dependente do nível da criança na sua escola.

As análises de variância unifatoriais (ANOVA) e o teste de Tukey não foram significativamente diferentes entre as três séries.

As taxas de análise da variância unifatorial encontradas de anisometropias esféricas e cilíndricas também não variaram significativamente considerando as três séries.

\section{INCISÕES RELAXANTES - COM DISSECÇÃO LAMELAR - NA CORREÇÃO DO ASTIGMATISMO APÓS CERATOPLASTIA PENETRANTE}

\section{Gleiton Carlos Mendonça Silva}

Orientador: Prof. Dr. Sidney Júlio de Faria e Sousa

Dissertação de Mestrado apresentada em 12/05/2006

Objetivos: avaliar a eficiência e previsibilidade de incisões relaxantes - com dissecção lamelar - na correção do astigmatismo após ceratoplastia penetrante. Avaliar ainda a influência do sexo, idade e patologias pré-operatórias no resultado cirúrgico final.

Materiais e Métodos: trinta pacientes, dezessete homens e treze mulheres, com idades variando entre dezoito e setenta e nove anos, foram submetidos a incisões relaxantes - com dissecção lamelar entre abril de 2003 e setembro de 2005. Dezenove pacientes eram portadores de ceratocone e onze apresentavam ceratopatia bolhosa. As incisões relaxantes foram realizadas no semimeridiano de maior curvatura na interface doador-receptor, com profundidade de 80 a $90 \%$ da espessura da córnea e $60^{\circ}$ a $90^{\circ}$ de arco de extensão; em seguida, foram realizadas dissecções das lamelas corneanas perpendiculares à incisão, com cerca de $2 \mathrm{~mm}$ em direção ao centro e ao limbo.
Resultados: a média de astigmatismo pré-operatório era de $8,69 \pm 2,42 \mathrm{D}$ e a média pós-operatória de 5,15 $\pm 2,46 \mathrm{D}$. A mudança astigmática em números absolutos no estudo foi de $3,49 \pm 2,30 \mathrm{D}$ ou $44,06 \% \mathrm{e}$ a mudança corrigida por análise vetorial foi de 6,74 \pm $2,97 \mathrm{D}$, o que corresponde a 78,55\% de correção do astigmatismo inicial. Não foram observadas diferenças estatisticamente significativas entre os resultados cirúrgicos comparados por sexo, idade ou patologia pré-operatória. Um paciente apresentou perfuração corneana, necessitando de sutura, e 20 pacientes permaneceram com astigmatismo superior a quatro $\mathrm{D}$ ao final do seguimento.

Conclusões: embora altamente seguras e eficientes na correção do astigmatismo após ceratoplastia penetrante, as incisões relaxantes apresentam baixa previsibilidade. A introdução das dissecções lamelares à técnica de incisões relaxantes aparentemente não torna seus resultados superiores a outros procedimentos para o mesmo fim; contudo, sua facilidade técnica pode representar uma vantagem, quando comparada a outros métodos de correção do alto astigmatismo após ceratoplastia penetrante.

\section{ESTUDO DESCRITIVO PARA DAWSON, TRICK E LITZKOW (DTL) EM ELETRORRETINOGRAMA DE CAMPO TOTAL PARA HUMANOS}

\section{Alexandre dos Reis Ráo}

Orientador: Prof. Dr. Rodrigo Jorge

Dissertação de Mestrado apresentada em 19/05/2006
Objetivos: A proposta deste estudo é descrever os valores obtidos em eletrorretinograma de campo total para humanos quando da utilização de um 
modelo específico de eletrodo, o Dawson, Trickn and Litzkow (DTL).

Métodos: Participaram desse estudo 19 voluntários normais com idades variando de 12 a 46 anos, sendo 12 mulheres e 07 homens. Os exames foram obtidos utilizando-se como aparelho o EPIC 2000 (LKC Technologies, inc., Gaithersburg, EUA), com o programa UTAS versão 3.10 e cúpula semi-automática de Ganzfield, com protocolo recomendado pela (ISCEV), rotina standard e utilizando o DTL como eletrodo ativo em ambos os olhos. Foram registrados a amplitude $\mu \mathrm{V}$ ) e o tempo implícito (ms) de resposta das cinco fases do exame. Realizou-se assim, o estudo descritivo dos dados obtidos.

Resultados: A média dos valores de amplitude $(\mu \mathrm{V})$ e tempo implícito $(\mathrm{ms})$ respectivamente:

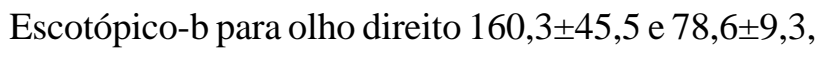
para o olho esquerdo $152,7 \pm 36,2$ e 79,4 $\pm 9,1$ : Onda-A para o olho direito $188,7 \pm 48,3$ e $18,0 \pm 2,8$, para o olho esquerdo $174,6 \pm 42,7$ e 17,4 42,5 ; Onda B para o olho direito $311,5 \pm 85,3$ e $45,2 \pm 3,4$, para o olho esquerdo 301,6 $6 \pm 74,2$ e 45,0 $0 \pm 3,0$; Potenciais Oscilatórios para olho $190,8 \pm 41,3$ e para olho esquerdo $192,6 \pm 43,8$; Fotópico b para o olho direito $134,7 \pm 35,0$ e $29,9 \pm 1,4$, para olho esquerdo $130,1 \pm 37,0$ e 29,7 $\pm 1,5$; Flicker para o olho direito $101,9 \pm 23,1$ e $26,8 \pm 1,6$, para olho esquerdo $96,1 \pm 22,6$ e $27,2 \pm 1,9$.

Conclusões: Esse estudo registra os valores obtidos em ERG de campo total utilizando-se DTL como eletrodo ativo. Essas informações possibilitam novos estudos comparativos e contribuem para futuras padronizações desse modelo de eletrodo.

\section{COMPARAÇÃO DOS RESULTADOS DA PERIMETRIA DE ONDAS CURTAS E DA PERIMETRIA DE DUPLA FREQÜENCIA EM PACIENTES COM SUSPEITA DE GLAUCOMA E HIPERTENSOS OCULARES DE ACORDO COM OS DIAGRAMAS DE BRUSINI}

\section{Marília Bastos Quirino Brasil}

Orientador: Prof. Dr. Argemiro Lauretti Filho

Tese de Doutorado apresentada em 02/06/2006

O glaucoma é uma neuropatia óptica progressiva com alterações típicas do campo visual, podendo ou não ser acompanhada por aumento de pressão intra-ocular. A necessidade do diagnóstico precoce desta doença se impõe pela irreversibilidade das alterações causadas pela doença e pelo fato de que esta pode permanecer assintomática até que sejam atingidos estágios avançados.

Em nosso estudo foram estudados trinta e cinco voluntários normais, vinte e nove pacientes com suspeita de glaucoma, treze pacientes com hipertensão ocular e trinta e dois pacientes com diagnóstico de glaucoma. Para o estudo, foi incluído um olho de cada paciente.

Todos os indivíduos foram submetidos à avaliação oftalmológica completa, seguida dos exames perimétricos (perimetria acromática, perimetria de ondas curtas e perimetria de dupla frequiência). Para avaliação da perimetria acromática e de dupla freqüência, considerou-se a escala proposta por Brusini (Glaucoma Staging System- GSS- e FDT Staging System - FDT-SS). Para análise da condordância dos resultados entre os métodos, foi utilizado o coeficiente de concordância Kappa.

Para o GSS observou-se sensibilidade de $100 \%$ e especificidade de $66 \%$. Para o FDT-SS observou-se sensibilidade de $100 \%$ e especificidade de $63 \%$. Em relação à perimetria de ondas curtas obteve-se uma sensibilidade de 59,37\% com especificidade de 85,7\%.

Pela análise do coeficiente Kappa, o GSS mostrou boa concordância quando considerados o grupo de normais $(\mathrm{K}=0,48 ; \mathrm{p}<0,001)$ e os grupos estudados como um todo $(\mathrm{K}=0,51 ; \mathrm{p}<0,001)$. Mostrou concordância moderada no grupo de glaucoma inicial $(\mathrm{k}=0,24$; $\mathrm{p}=0,26)$ e concordância quase perfeita no grupo de glaucoma moderado $(k=0,88 ; \mathrm{p}<0.001)$.

No grupo de suspeitos e hipertensos oculares, o FDT-SS foi o método com maior positividade para a doença $(55,17 \%$ e $53,85 \%$ respectivamente), tendo sido este índice maior que o índice de falsos positivos do mesmo exame $(37,14 \%)$.

O FDT-SS mostrou moderada concordância no grupo de normais $(\mathrm{K}=0,38 ; \mathrm{p}=0,017)$, de iniciais $(\mathrm{K}=0,26 ; \mathrm{p}=0,294)$ e nos grupos como um todo $(\mathrm{K}=0,35$; $\mathrm{p}=0,003)$. No grupo com glaucoma moderado, observou-se boa concordância $(K=0,43 ; p=0,092)$.

O FDT-SS e o GSS mostraram ótimos índices de sensibilidade (100\%). No entanto, a especificidade 
observada foi inferior àquela reportada em outros estudos (63 e $66 \%$ respectivamente).

A perimetria de ondas curtas mostrou maior especificidade que os outros dois métodos em estudo $(85,7 \%)$, mas provavelmente em detrimento da sensibilidade $(59,37 \%)$.
Os achados do estudo apontam para a perimetria de dupla frequiência pelo método FDT-SS como exame mais sensível que a perimetria de ondas curtas para o diagnóstico de glaucoma, com índice de positividade maior também nos grupos de hipertensos oculares e suspeitos de glaucoma.

\section{ORTOPEDIA}

\section{LESÃO POR ESMAGAMENTO DO NERVO ISQUIÁTICO DE RATOS: ESTUDO DA VASCULARIZAÇÃO}

\author{
Célia Aparecida Stellutti Pachioni \\ Orientador: Prof. Dr. Nilton Mazzer \\ Tese de Doutorado apresentada em 30/05/2006
}

Este trabalho teve como objetivo estudar as alterações microvasculares intraneurais agudas em nervo isquiático de rato submetido à esmagamento por diferentes cargas. Foram utilizados sessenta ratos machos da linhagem Wistar, distribuídos em dois grupos experimentais de acordo com o protocolo de injeção de vasos e subdivididos de acordo com a carga de esmagamento. Os nervos isquiáticos direitos de cada grupo experimental foram isolados e submetidos ao esmagamento com diferentes cargas $(0,5 \mathrm{Kg}, 1,0 \mathrm{Kg}$, $5,0 \mathrm{Kg}, 10,0 \mathrm{~kg}$ e $15,0 \mathrm{~kg}$ ) por 10 minutos e os nervos isquiáticos esquerdos foram utilizados como controle. Após o esmagamento, 30 animais foram submetidos ao Protocolo I, que constou de: cateterização da aorta abdominal, perfusão manual da solução composta de tinta da China e gelatina 5\% em formol 10\%, dissecação e retirada dos nervos direitos e esquerdos, desidratação e diafanização para análise longitudinal dos vasos intraneurais. Os outros trinta animais foram sub- metidos ao Protocolo II, que constou de: cateterização da aorta abdominal e perfundidos com solução composta de tinta da China e gelatina $5 \%$ em soro fisiológico e, após, mantidos em freezer $-20^{\circ} \mathrm{C}$ por uma hora. Em seguida os nervos foram dissecados e retirados em toda a sua extensão, cortados em 3 fragmentos, congelados em isopentano em gelo seco e armazenados em freezer $-70^{\circ} \mathrm{C}$, seccionados em cortes transversais semi-seriados em criostato para análise e contagem dos vasos intraneurais. Os resultados mostraram regiões de hematoma endoneural e epineural nas diferentes cargas utilizadas indicando que as forças de esmagamento foram suficientes para lesar os vasos intraneurais do nervo isquiático, especialmente com cargas elevadas. A análise morfométrica mostrou um comportamento diferente nas três regiões estudadas, constatando menor número de vasos na região do esmagamento e não nas regiões acima e abaixo da mesma. Estes resultados sugerem lesão localizada dos vasos intraneurais que foi proporcional à carga de esmagamento, causando hematoma endoneural e epineural, o que criará um microambiente desfavorável para a regeneração das fibras nervosas que também foram lesadas nesse modelo.

\section{ESTABILIZAÇÃO PRIMÁRIA DA DIÁFISE UMERAL: ESTUDO EXPERIMENTAL DE DIFERENTES MÉTODOS DE OSTEOSSÍNTESE}

Vilson Ulian

Orientador: Prof. Dr. Nilton Mazzer

Tese de Doutorado apresentada em 31/05/2006
Este estudo experimental foi idealizado com o objetivo de avaliar a estabilização relativa primária da diáfise umeral com três diferentes métodos de oste- 
ossíntese, representados por uma placa tipo DCP aplicada com técnica em ponte e que já está sendo utilizada na prática clínica apesar de não ter sido encontrada referência em literatura sobre estudos experimentais com placas em ponte. $\mathrm{O}$ segundo material utilizado foi uma síntese elástica, também incomum, denominada de SPS ${ }^{\circledR}$, também aplicada em forma de ponte e que não foi encontrado similar na literatura. Um terceiro material utilizado foi uma haste intramedular com um incomum método de bloqueio proporcionado por um parafuso cortical distalmente e por um fio do tipo Ender proximalmente. Para esse fim foram coletados 21 pares de úmeros humanos de cadáveres a fresco, respeitando-se a normalização bioética da doação e coleta de material humano, bem como as normas de funcionamento do CEMEL-Centro de Medicina Legal da FMRP. Os espécimes coletados foram preparados e adequadamente armazenados no laboratório de bioengenharia da FMRP, onde também foram realizados os procedimentos de osteotomia e aplicação das técnicas cirúrgicas para montagem das sínteses ósseas, obedecendo as especificações técnicas próprias de cada material. Com a utilização de uma máquina universal de ensaios EMIC® DL 10000, os três grupos foram submetidos a ensaios não destrutivos de flexo-compressão e de torção, com limites de carga de $200 \mathrm{~N}$ e $100 \mathrm{~N}$ respectivamente, que numa primeira fase foram denominados de experimentos primários e num mecanismo de "crossing" foram submetidos secundariamente a novos ensaios, amparados por análise estatística. Os resultados obtidos para o grupo da placa DCP em ponte mostraram boa resistência às cargas aplicadas, comportamento este seguido pelo grupo da síntese elástica que apesar de mostrar índices maiores de deflexão, apresentou grande capacidade elástica. $\mathrm{O}$ grupo da haste intramedular mostrou bons resultados nos ensaios de flexocompressão devido ao mecanismo de tutor das hastes intramedulares, mas não mostrou resistência às cargas de torção.

\section{AVALIAÇÃO DA DOR PÓS-OPERATÓRIA DURANTE A FISIOTERAPIA EM CRIANÇAS SUBMETIDAS À CIRURGIA CARDÍACA}

\section{Adriana Sanches Garcia \\ Orientador: Prof.Dr. Jyrson Guilherme Klamt \\ Dissertação de Mestrado apresentada em 09/06/06}

O objetivo deste estudo foi mensurar a dor, e as alterações fisiológicas (pressão arterial (PA), freqüência cardíaca (FC), freqüência respiratória (FR), e saturação arterial de oxigênio $\left.\left(\mathrm{SpO}_{2}\right)\right)$ durante a fisioterapia respiratória no período pós-operatório em crianças submetidas à cirurgia cardíaca, e correlacionar as variáveis fisiológicas com os escores da escala de dor. As 18 crianças, submetidas à cirurgia cardíaca com indicação de fisioterapia pós-operatória, foram avaliadas pré-fisioterapia quanto à pressão arterial sistólica (PAS) e diastólica (PAD), FC, $\mathrm{SpO}_{2}$, FR , e aplicada escala de dor FLACC. Os parâmetros fisiológicos foram medidos imediatamente antes, após cinco e dez minutos do início da fisioterapia, ao término e após cinco minutos do término da fisioterapia. A Dor foi avaliada imediatamente antes, dez minutos do início da fisioterapia e após cinco minutos do término. As variáveis FC, FR e PA aumentaram significativamente em todos os momentos avaliados quando comparados com os valores observados antes do início da fisioterapia. $\mathrm{A} \mathrm{SpO}_{2}$ reduziu em todos os momentos, sem atingir significância. Houve aumento da intensidade da dor nos dois momentos avaliados, sendo significativo apenas no momento cinco minutos do término da fisioterapia. A correlação entre os valores da escala de dor e as varáveis fisiológicas foi negativa no momento dez minutos do início da fisioterapia para FC e FR. A fisioterapia respiratória no pós-operatório de cirurgia cardíaca em crianças pode causar alterações fisiológicas decorrentes da dor, como também, estas alterações podem ser decorrentes de regulação hemodinâmica.

\section{AVALIAÇ̃̃o QUALITATIVA E QUANTITATIVA DAS LESÕeS AGUDAS POR ESMAGAMENTO DO NERVO ISQUIÁTICO DO RATO}

\section{Patrícia Yumi Cantalejo Nagima Mazzer}

Orientador: Prof.Dr. Claúdio Henrique Barbieri

Tese de Doutorado apresentada em 29/06/2006
Um estudo morfológico e morfométrico das lesões agudas por esmagamento do nervo isquiático foi realizado em ratos. Vinte e cinco ratos Wistar machos 
foram utilizados e divididos em cinco grupos de cinco animais cada, de acordo com a carga de esmagamento. O nervo isquiático direito foi exposto por uma incisão cutânea longitudinal na face lateral da coxa e submetido a uma lesão por esmagamento, em um segmento intermediário, de $5 \mathrm{~mm}$ de comprimento durante 10 minutos, utilizando um dispositivo de peso-morto especialmente projetado e construído para este propósito, com cargas de $500 \mathrm{~g}, 1.000 \mathrm{~g}, 5.000 \mathrm{~g}, 10.000 \mathrm{~g} \mathrm{e}$ $15.000 \mathrm{~g}$, de acordo com grupo. Os animais foram mortos com uma dose excessiva de anestésico, 72 horas após o procedimento de esmagamento e submetidos, imediatamente, à perfusão com uma solução fixadora injetada na aorta abdominal. Ambos os nervos isquiáticos, direito (esmagado) e esquerdo (controle), foram então pós-fixados com a mesma solução durante 24 horas e preparados por técnicas histológicas convencionais. Secções transversais de $5 \mu \mathrm{m}$ de espessura foram obtidas e coradas com azul de toluidina a $1 \%$ e analisadas em um microscópio de luz equipado com uma câmera de vídeo acoplada a um micro computador carregado com um programa gráfico (KS 400). Foram realizados estudos morfológicos qualitativos e morfométricos quantitativos, para calcular parâmetros como densidade de fibras normais e alteradas, área e diâmetro mínimo da fibra, área e diâmetro mínimo do axônio e razão G. Os resultados mostraram que a lesão produzida às fibras neurais e ao tecido neural foi diretamente proporcional à carga aplicada e que uma carga de $500 \mathrm{~g}$ é suficiente para produzir um dano severo, com lesão importante das estruturas do endoneuro.

\section{INDUÇÃO DE ÚLCERA CUTÂNEA NA REGIÃO DORSAL DE RATOS WISTAR POR MEIO DE INOCULAÇÃO SUBCUTÂNEA DE FORMALDEÍDO A $40 \%$. ESTUDO EXPERIMENTAL}

\section{João Fabio Rodrigues Siqueira}

Orientador: Prof.Dr. Claúdio Henrique Barbieri

Dissertação de Mestrado apresentada em 30/06/2006

O presente trabalho tem como objetivo desenvolver um protocolo experimental de indução de úlcera cutânea, por meio de inoculação subcutânea de formaldeído $40 \%$, e estudar a evolução de suas características histológicas, na epiderme, derme, tecido muscular, através da análise do espectro de cor. Considerando os mecanismos de evolução de uma úlcera pressão como parâmetro, para desenvolvimento da úlcera cutânea. Utilizamos 72 ratos Wistar, macho. Os animais. foram divididos em três grupos denominados: GRUPO I (controle - composto de 24 animais, induzido 24 úlceras cutânea com inoculação de solução salina $0,9 \%$ na dosagem de $30 \mu \mathrm{l}$, por via subcutânea), GRUPO II (experimental 1 - composto de 24 animais, induzido 24 úlceras cutânea com inoculação de solução formaldeído $40 \%$ na dosagem de $50 \mu \mathrm{l}$ por via subcutânea), GRUPO III (experimental 2 - composto de 24 animais, induzido 24 úlceras cutâneas com aplicação de solução formaldeído $40 \%$ na dosagem de 30 $\mu 1$ por via subcutânea). No procedimento de indução da úlcera, os animais sofreram anestesia geral, administrada com associação dos anestésicos Ketamina (90mg/Kg) associado com Xilasina $(10 \mathrm{mg} / \mathrm{Kg})$, por via intra-peritoneal, e 1/3 desta dose foi utilizada como forma de manutenção dos níveis de anestesia durante o experimento, com um tempo médio de ação de 4 minutos, não causando nenhuma alteração nos parâmetros fisiológicos e demais funções vitais. O procedimento de indução da úlcera cutânea foi realizado conforme o grupo induzido, ambos sendo realizados por via subcutânea, na região dorsal do animal envolvido neste experimento. Os animais foram monitorados por um período de 72 horas, ocorrendo retirada de material para análise histológica em todos os grupos, no seguinte momento: seis animais de cada grupo - 6 horas após indução da úlcera cutânea, seis animais de cada grupo - 24 horas após indução da úlcera cutânea, seis animais de cada grupo - 48 horas após indução da úlcera cutânea, seis animais de cada grupo - 48 horas após indução da úlcera cutânea, seis animais de cada grupo - 72 horas após indução da úlcera cutânea. Após a retirada da amostra histológica, os segmentos foram fixados em formol a $10 \%$ por 24 horas, e corados pela técnica hematoxilina-eosina (HE). Utilizou-se o software Ks $400 \mathrm{GmbH}$, para análise morfométrica da área de epiderme, área de derme, área de tecido muscular e espessura média da epiderme. Os resultados obtidos por inoculação demonstram que a indução da úlcera cutânea por meio de inoculação de formaldeído é um protocolo confiável e de fácil exe- 
cução. Os dados obtidos das amostras retiradas a $6^{a}$, $24^{\mathrm{a}}, 48^{\mathrm{a}}$ e $72^{\mathrm{a}}$ horas pós-indução para o percentual de área lesada de derme, epiderme e tecido muscular, foram tratados estatisticamente por análise de variância
(ANOVA) fixou-se em 0,05 ou 5\% o nível de significância. Podemos concluir que: o protocolo de indução é um método satisfatório quanto ao desenvolvimento de uma lesão que não cicatrize espontaneamente.

\section{OTORRINOLARINGOLOGIA}

\section{AVALIAÇÃO VESTIBULAR POR MEIO DE VIDEONISTAGMOGRAFIA DE PA- CIENTES PORTADORES DE DEFICIÊNCIA CRÔNICA DE ZINCO POR SÍN- DROME DO INTESTINO CURTO}

\section{Gustavo Duarte Paiva Ferreira}

Orientadora: Profa.Dra. Maria Cristina L. Cury Féres Dissertação de Mestrado apresentada em 20/04/2006

A presença do elemento químico zinco na via auditiva e a sua provável participação na gênese de alguns tipos de disacusia e tinnitus estão bem documentadas, porém não há estudos funcionais que mostrem o impacto da deficiência sistêmica de zinco no sistema vestibular, nem estudos anatômicos descritivos comprovando a existência do íon nas estruturas da via vestibular. Este estudo foi realizado com o ob- jetivo de relacionar a alteração na homeostase do zinco com anormalidades do funcionamento da via vestibular. Nove indivíduos portadores de deficiência crônica de zinco, entre outros distúrbios nutricionais, conseqüentes à síndrome de má absorção, foram submetidos à avaliação vestibular. Os resultados foram comparados com os de um grupo controle considerado normal. A comparação entre os grupos mostrou diferenças significativas em diversos parâmetros da análise vestibular e chamou a atenção para uma possível participação das alterações disabsortivas na origem das desordens vestibulares.

\section{POTENCIAIS EVOCADOS AUDITIVOS DE TRONCO ENCEFÁLICO EM PACIEN- TES COM SÍNDROME DE MÁ ABSORÇÃO POR SÍNDROME DO INTESTINO CURTO, ANTES E APÓS REPOSIÇÃO PẢRENTERAL DE OLIGOELEMENTOS}

\section{Júlio Cláudio Sousa}

Orientadora: Profa. Dra. Maria Cristina L. Cury Féres Dissertação de Mestrado apresentada em 20/04/2006

O elemento químico zinco tem sido muito estudado recentemente. Sabe-se hoje que, além de seu importante papel no equilíbrio nutricional do organismo, o zinco está presente em várias e diferentes estruturas do sistema nervoso central (SNC), atuando como co-fator em sinapses excitatórias glutamatérgicas. Acredita-se que o zinco module a sensibilidade de receptores pós-sinápticos de glutamato, do tipo $\mathrm{N}$ Metil-D-Aspartato (NMDA). Este trabalho visa estudar um grupo de pacientes com hipozincemia crônica, decorrente da Síndrome do Intestino Curto (SIC), an- tes e após a reposição parenteral desse oligoelemento, através de Potenciais Evocados Auditivos de Tronco Encefálico (PEA), e compará-lo a um grupo de pacientes controle, sem queixas otológicas, sem doença nutricional, para avaliar a possível presença de alterações funcionais da via auditiva, assim como o efeito da reposição parenteral de zinco sobre essa função. Os pacientes do grupo hipozincêmico foram recrutados na Unidade Metabólica do Hospital das Clínicas da Faculdade de Medicina de Ribeirão Preto da Universidade de São Paulo (HCFMRP-USP), Disciplina de Nutrologia. Todos foram submetidos à anamnese, exame físico otorrinolaringológico, dosagem de zinco, glicemia e hormônios tireoideanos, Audiometria Tonal Liminar, Imitanciometria, Índice Percentual de Reco- 
nhecimento de Fala e, em seguida, ao exame de PEA. Os pacientes do grupo hipozincêmico foram submetidos a novo exame de PEA vinte quatro horas após a reposição parenteral de zinco. Os resultados dos dois grupos foram compilados e submetidos à análise estatística. Observou-se um aumento significativo no intervalo inter-pico I-V, entre o grupo controle e os pacientes hipozincêmicos, ao exame de PEA. No grupo hipozincêmico, antes e após a reposição parenteral de zinco, não se detectaram diferenças significativas. Conclui-se que os pacientes com desequilíbrio nutricional, o qual compreende deficiência de zinco, apresentaram alteração funcional do sistema auditivo, detectável eletrofisiologicamente ao PEA, e que a reposição parenteral aguda de zinco não alterou o perfil eletrofisiológico auditivo desses pacientes.

\section{DACRIOCISTORRINOSTOMIA ENDOCANALICULAR COM LASER DE DIODO}

\section{Pedro Paulo Vivacqua da Cunha Cintra} Orientadora: Profa. Dra. Wilma T. Anselmo-Lima Tese de Doutorado apresentada em 15/05/2006

Nos últimos anos a procura por métodos cirúrgicos menos invasivos e com resultados que fossem semelhantes aos utilizados tem sido a norma na medicina. Assim, surgiram os lasers cirúrgicos, possibilitando, a nós médicos, procedimentos de uma precisão inimaginável há alguns atrás.

Neste trabalho, o nosso objetivo foi avaliar e comparar os resultados da dacriocistorrinostomia endocanalicular (DCR ECN) com laser de diodo e a técnica tradicional de dacriocistorrinostomia endonasal DCR EDN realizadas em pacientes selecionados, portadores de estenose comprovada por dacriocistografia das vias lacrimais.

Realizamos 28 cirurgias de DCR ECN com laser de diodo Diomed 15 e 24 cirurgias de DCR EDN no período de fevereiro de 2002 a julho de 2005.

Em nossos resultados o tempo cirúrgico com a DCR ECN foi de 29 minutos, e da DCR EDN 86 minutos, estatisticamente significativo.

No grupo DCR ECN, 25 (88\%), apresentavam- se sem queixas após o procedimento e três (12\%) apresentaram ausência de melhora dos sintomas após o procedimento cirúrgico, ao passo que no grupo DCR EDN 19 pacientes $(79 \%)$ apresentaram resultados positivos e 5 pacientes (21\%) mantiveram os seus sintomas iniciais, não havendo diferença significativa no percentual entre os grupos.

O tempo de silicone dos pacientes do grupo DCR ECN (55 dias) foi significativamente inferior ao tempo de tubo dos pacientes do grupo DCR EDN (117 dias).

Nos parâmetros avaliados somente na DCR ECN verificamos que a quantidade de energia variou de 289 a 523J, a anestesia local associada à sedação foi bem suportada por todos os pacientes. O sangramento intra-operatório foi classificado como ausente em dois procedimentos $(7,14 \%)$, leve em dezessete pacientes $(60,71 \%)$, moderado em nove pacientes $(32,14 \%)$ e em nenhum paciente foi necessário interromper o procedimento por sangramento.

Concluímos que as duas técnicas apresentaram bom índice de resolutibilidade, sem diferença significativa entre elas. Destacamos as facilidades oferecidas pela DCR ECN apesar da desvantagem que é o custo alto do equipamento.

\section{ALTERAÇÕES HISTOLÓGICAS PRODUZIDAS POR SUBSTÂNCIAS ESCLERO- SANTES E RADIOFREQÜÊENCIA NO PALATO MOLE EM MODELO ANIMAL}

\section{Ralph Silveira Dibbern}

Orientador: Prof. Dr. Denilson S. Fomin

Dissertação de Mestrado apresentada em 17/05/2006

Objetivos: Este estudo foi realizado para comparar as mudanças histológicas no palato mole em modelo canino após o uso de Radiofrequiência e substâncias esclerosantes, verificando as alterações estruturais de mucosa e submucosa, assim como os tipos de colágeno. Estas técnicas cirúrgicas são usadas no tratamento do ronco e apnéia leve do sono para aumentar a tensão e reduzir o palato mole. 
Métodos: Dezesseis animais foram divididos em 5 grupos: grupo 1, cães submetidos à injeção de oleato de etanolamina, grupo 2, cães submetidos à injeção de glicose 50\%, grupo 3, cães submetidos à Radiofreqüência-Coblation, grupo 4, com cães submetidos à redução volumétrica do palato mole com Radiofreqüência-Somnoplastia e o grupo 5 como controle. Após 5 semanas, os animais foram sacrificados. A porção de mucosa e submucosa foi analisada com coloração picrosirius e observada com microscopia de polarização. As análises estatísticas foram feitas pelos modelos lineares de efeitos mistos (efeitos aleatórios e fixos), através do procedimento PROCMIXED do software SAS, versão 8.02.
Resultados: A análise histológica demonstrou o aumento do colágeno tipo I em relação ao tipo III em todos os grupos submetidos à Radiofreqüência e substâncias esclerosantes, quando comparados ao grupo controle.

Conclusões: Os tipos de colágeno mais evidentes no palato mole foram os tipos I e tipo III, após o procedimento, sendo o colágeno tipo I presente em maior quantidade naqueles submetidos ao oleato de etanolamina e Radiofreqüência-Somnoplastia. A análise histológica também demonstra ausência de processos inflamatórios crônicos ou necrose de mucosa e submucosa.

\section{AVALIAÇÃO DOS POTENCIAIS EVOCADOS AUDITIVOS RELACIONADOS A EVENTOS EM PACIENTES PORTADORES DE DOENÇA DE ALZHEIMER}

\section{Camila de Giacomo Carneiro}

Orientadora: Profa. Dra. Maria Cristina L.Cury Féres Dissertação de Mestrado apresentada em 18/05/2006

A Doença de Alzheimer é a doença neurodegenerativa mais comum e a causa mais prevalente de demência no idoso.

O componente $\mathrm{P} 300$ dos potenciais evocados relacionados a eventos tem sido usado na avaliação dos distúrbios cognitivos, em várias doenças do Sistema Nervoso Central.

O presente trabalho teve como objetivo avaliar o comportamento dos potenciais evocados auditivos de longa latência em pacientes portadores de Doença de Alzheimer. Foram analisadas as latências e as amplitudes dos componentes N1, P2, N2 e P300 desse tipo de potencial.

Detectou-se diferença estatisticamente significativa na latência e na amplitude do $\mathrm{P} 300$ nos pacientes com Doença de Alzheimer, em relação ao grupo controle.

Concluiu-se que o P300 pode ser utilizado na avaliação complementar desse tipo de desordem cognitiva.

\section{ANÁlISE HISTOLÓGICA DA FORMAÇÃO DE COLÁGENO DO PALATO MOLE APÓS UTILIZAÇÃO DE BISTURI ULTRASSÔNICO E ELETROCAUTÉRIO EM MODELO ANIMAL}

\section{Fernando Arruda Ramos}

Orientador: Prof. Dr. Denilson S. Fomin

Dissertação de Mestrado apresentada em 22/05/2006

Objetivos: Analisar a quantidade média do colágeno total produzido e o tipo predominante de colágeno no palato mole animal, após a utilização do Bisturi Ultrassônico e Eletrocautério, em relação à análise histológica do palato mole do animal suíno controle.

Métodos: Foram incluídos neste estudo onze suínos. Dez foram submetidos à retirada da úvula ao nível do bordo inferior do pilar anterior do palato mole e incisões laterais verticais à úvula, a meia distância entre a margem lateral da úvula à parede lateral da faringe e um utilizado como controle. Em cinco foi utilizado o Bisturi Ultrassônico e em cinco o Eletrocautério Monopolar, com incisões laterais verticais aproximadas de $0,5 \mathrm{~cm}$ no palato mole e redução da úvula. O palato mole dos animais suínos foi retirado após cinco semanas do procedimento. Os cortes foram corados em uma solução de 0,1g de Sírius Red, em 100ml de solução de ácido pícrico saturado de pH 
2.0, método Picrosírius. As lâminas contendo os cortes corados com o Sírius Red foram observadas e fotografadas por microscopia de luz em microscópio sob polarização. Foram preparados quatro blocos de cada animal, cada bloco foi cortado quatro vezes, sendo analisado os três primeiros cortes e descartado o último corte, correspondente a porção mais interna do bloco. Cada corte foi fotografado seis vezes, sendo seguido o critério pré-determinado para todos os cortes. Cada bloco foi fotografado dezoito vezes, totalizando 72 fotos por animal.

Resultados: Houve aumento na quantidade média de colágeno total após a utilização do Bisturi Ultrassônico em relação ao animal controle, porém, redução na quantidade média de colágeno total com o uso do Eletrocautério. Houve aumento do colágeno tipo III e diminuição do colágeno tipo I utilizando Eletrocautério e diminuição do colágeno tipo III e aumento do colágeno tipo I utilizando Bisturi Ultrassônico. O tipo de colágeno predominante nas duas técnicas foi colágeno Tipo I.

Conclusão: $O$ procedimento com Eletrocautério diminuiu a quantidade média de colágeno total e do tipo I e aumentou a do tipo III. O procedimento com Bisturi Ultrassônico aumentou a quantidade média de colágeno total e do tipo I. Para o futuro o uso do Bisturi Ultrassônico poderá ser utilizado para tratamentos que exijam aumento do colágeno tipo I para melhoria dos sintomas, porém, novos estudos devem ser realizados para comprovarem nossos achados.

\section{COMPARAÇÃO DE TIREOIDECTOMIAS PARCIAIS REALIZADAS SOB A AÇÃO DE ANESTESIA GERAL E BLOQUEIO DO PLEXO CERVICAL SUPERFICIAL}

\section{Helder Raful}

Orientador: Prof. Dr. Rui C. Martins Mamede

Dissertação de Mestrado apresentada em 22/05/2006

Introdução: A tireoidectomia ao agregar ao seu arsenal o que há de mais moderno em termos de técnica e instrumentais, passou de ato temido a uma das cirurgias mais freqüentemente realizadas na área de Cirurgia de Cabeça e Pescoço. No entanto, a sua realização sob efeito do bloqueio do plexo cervical superficial tem encontrado resistência.

Objetivo: Comparar duas técnicas anestésicas (anestesia geral e bloqueio do plexo cervical superficial) em pacientes submetidos à hemitireoidectomia de acordo com: tempo cirúrgico, anestésicos, de reversão e de recuperação anestésica, complicações, necessidade de analgesia, tamanho da tumoração ressecada, grau de satisfação e custos do tratamento.

Materiais e Métodos: Foram analisados 42 pacientes submetidos à hemitireoidectomia sob o efeito de duas diferentes técnicas anestésicas. Eram pacientes com indicação cirúrgica baseada nos dados ultrasonográficos e de PAAF, sendo que 21 receberam anestesia geral (A.G.) e outro tanto o bloqueio do plexo cervical superficial (B.P.C.S.), de forma intercalada. Todos receberam meperidina e prometazina com o intuito de sedar os pacientes. No grupo submetido ao B.P.C.S., usou-se marcaína a $0,5 \%$ com vasoconstrictor, no ponto de ERB, e quando necessário, lidocaína a $2 \%$ com vasoconstrictor para complementação anestésica intra-operatória. Sedação intra-operatória com diazepam endovenoso foi administrada, conforme a necessidade, e metoprolol para controle da pressão arterial (PA) e frequiência cardíaca (FC) intra-operatória. O grupo submetido à A.G. foi anestesiado segundo técnica padronizada pelo grupo de anestesistas do hospital onde se desenvolveu o estudo. Para isso receberam: ar, oxigênio, óxido nitroso, etomidato, eflurano, fentanil, pancuron, droperidol, prostigmine e atropina.

Resultados: Tivemos resultado significante $(\mathrm{p}<0,05)$ para o tempo de cirurgia (A.G.111, 4: B.P.C.S.125,5min.), tempo de anestesia (A.G.154,1: B.P.C.S.488,6min), tempo de reversão anestésica (A.G.15:B.P.C.S.1min.) e custos do tratamento (A.G.203,2:B.P.C.S.87,4R \$) e resultado não significativo (p>0,05) para tempo de internação (A.G.17,3: B.P.C.S.15,1h), sangramento intra-operatório (A.G.41,9:B.P.C.S.47,6g), tamanho do tumor ressecado (A.G.52,1: B.P.C.S.93,69 $\mathrm{cm}^{3}$ ), tempo de permanência na sala de recuperação anestésica (A.G.110,5: B.P.C.S.91,0min.) e grau de satisfação dos pacientes (A.G.3,8:B.P.C.S.3,9).

Conclusão: Levando-se em conta os resultados obtidos nesse estudo, os valores significantes, foram: o tempo cirúrgico foi maior com B.P.C.S. 
(14,1 min.); o tempo de reversão em sala cirúrgica foi maior com A.G. (14 min.), o tempo anestésico foi maior com B.P.C.S. (334,5 min.), porém, este fato não implicou em redução do uso de analgésico no pós- operatório imediato; houve trauma laringo-traqueal em $51 \%$ dos A.G. e bradicardia em $23,8 \%$ do B.P.C.S., houve custo menor do tratamento com B.P.C.S. $(\mathrm{R} \$ 115,8)$.

\section{NISTAGMO OPTOCINÉTICO EM INDIVÍDUOS COM ALTERAÇÕES CEREBE- LARES}

Alexandre Truite Alves

Orientador: Prof. Dr. José Fernando Colafêmina

Dissertação de Mestrado apresentada em 23/05/2006

Parte integrante de testes da oculomotricidade, o nistagmo optocinético representa um movimento ocular involuntário de acompanhamento visual à objetos em movimento. É constituído por um movimento ocular suave em direção ao estímulo visual móvel sucedido de movimentação rápida em direção oposta. Sua função é de ajudar na estabilização da cena visual na retina, para compensar o movimento do campo visual. As vias neurais geradoras deste possui conexões importantes com o cerebelo. Sabe-se que lesões cerebelares, dos mais diversos tipos, podem provocar alterações qualitativas no nistagmo optocinético. Neste estudo, à princípio, foi realizada uma revisão de literatura com ênfase nas relações entre o cerebelo e o nistagmo optocinético. Foram constituídos 2 grupos distintos de indivíduos: um grupo de 6 indivíduos com diversos tipos de patologia do cerebelo, com idade vari- ando entre 35 e 46 anos, e um grupo controle, constituído por 17 indivíduos voluntários com idade variando entre 18 e 50 anos. O nistagmo optocinético foi analisado em ambos os grupos, utilizando-se como parâmetro quantitativo a variável ganho e como parâmetro qualitativo a morfologia dos registros. A comparação da variável ganho foi realizada entre os dois grupos e a seguir entre ambos os sexos. O aparelho utilizado foi um eletronistagmógrafo computadorizado de 4 canais da marca Micromedical Technologies. Não foram encontradas diferenças no parâmetro quantitativo (ganho) nos dois grupos (controle e patológico). Sexo também não exerceu influência nesta comparação. A morfologia das respostas, porém, apresentou profundas diferenças entre os dois grupos, sendo que o grupo com doenças cerebelares apresentou assimetria nas respostas entre olho esquerdo e olho direito. Assim, conclui-se que o cerebelo possui relações importantes neurais com o nistagmo optocinético e que novos estudos sobre as relações, envolvendo eletronistagmografia devem ser realizados.

\section{PATOLOGIA}

\section{EFEITOS DO ORLISTAT NA PROLIFERAÇÃO CELULAR DA MUCOSA COLÔNICA E NA FORMAÇÃO DE FOCOS DE CRIPTAS ABERRANTES INDUZIDOS POR DIMETILHIDRAZINA EM RATOS}

\section{Luane Taísa da Costa Barros}

Orientador: Prof. Dr. Sérgio Britto Garcia

Dissertação de Mestrado apresentada dia 24/04/2006

O Orlistat é um membro de uma classe de drogas usadas como tratamento para obesidade. No entanto, a segurança de seu uso em longo prazo ainda não é conhecida. O Orlistat exerce sua atividade no lúmen do trato gastrintestinal inibindo a enzima lipase pancreática, responsável pela hidrólise dos triacilglicerídeos normalmente ingeridos com a dieta. Esse medicamento, quimicamente sintetizado, é um derivado da lipstatina, inibidora natural da lipase produzida pelo Streptomyces toxytricini. Assim, a excreção de gordura fecal fica significativamente aumentada com o uso do Orlistat. Estudos epidemiológicos e 
em modelos experimentais, sugerem que o aumento das dietas hipergordurosas tem efeito promotor para o câncer colorretal. Tal efeito deve ser relacionado, pelo menos parcialmente, às mudanças intra-colônicas causadas pela ação direta da gordura nas células da mucosa do cólon, os colonócitos. O estudo atual tem como objetivo verificar os efeitos do Orlistat na formação colônica de focos de criptas aberrantes (FCA) e na proliferação celular epitelial da mucosa gastrintestinal.

Ratos Wistar machos receberam dieta padrão ou dieta com aumento de gordura, suplementada ou não com Orlistat (200 mg / kg), e duas doses semanais do carcinógeno químico Dimetilhidrazina (DMH) $(25 \mathrm{mg} / \mathrm{kg}$ ). Após 30 dias, nos animais tratados com $\mathrm{DMH}$, o Orlistat foi associado a um aumento significativo no número de FCAs colônicos e na proliferação celular epitelial da mucosa do cólon, independentemente da dieta. Os achados obtidos neste trabalho permitem concluir que o aumento do teor de gordura na luz do cólon distal, em decorrência da ação do Orlistat, pode potencializar a ação da DMH na formação de FCAs e no aumento da proliferação celular epitelial da mucosa colônica.

\section{A INTERFERÊNCIA DOS HORMÔNIOS SEXUAIS NO TEMPO DE ESQUELETI- ZAÇÃO. ESTUDO EXPERIMENTAL EM RATOS WISTAR}

\section{Ricardo Marcelo Abrão}

Orientadora: Profa. Dra. Carmen Cinira Santos Martin Tese de Doutorado apresentada em 17/05/06

Pesquisas têm documentado como é variável a decomposição corporal e o intervalo de tempo verificado entre as diversas fases do processo de decomposição do cadáver e o momento em que se verificou a morte. Fatores ambientais como temperatura, umidade, condições aeróbica e anaeróbica, presença de microrganismos e condições do solo são considerados como fatores que interferem no processo que envolve a preservação ou não do cadáver. As circunstâncias que detêm a putrefação, uma vez iniciada, estão representadas pelos processos naturais conservadores dos cadáveres. A formação da adipocera foi investigada para confirmar a sua relação com o tempo de esqueletização relacionado ao sexo. $\mathrm{O}$ trabalho teve os seguintes objetivos: 1) registrar e comparar as variáveis ambientais temperatura, umidade relativa do ar, chuvas e as variáveis corporais peso e teor de gordura dos animais; 2) investigar se o processo de esqueletização sofre interferência hormonal, descrevendo, macroscopicamente, a esqueletização comparando-se os grupos conforme o sexo e a fase hormonal e 3) identificar a composição da massa cadavérica dos restos da decomposição corpórea através do método da cromatografia gasosa. Trata-se de trabalho experimental com ratos Wistar sendo utilizados 30 ratos divididos em três grupos: 10 machos castrados sem reposição de testosterona (MCST), 10 machos castrados com reposição de testosterona (MCCT) e 10 machos controles da testosterona (MCoT). Para a formação do grupo das fêmeas foram utilizadas 60 ratas divididas em seis grupos: 10 fêmeas controles na fase diestro (FCoD), 10 fêmeas controles na fase estro (FCoE), 10 fêmeas controles na fase proestro (FCoP), 10 fêmeas castradas sem reposição de hormônio (FCSH), 10 fêmeas castradas com reposição de estrógeno (FCCE) e 10 fêmeas castradas com reposição de progesterona (FCCP). Estes animais foram cuidados até atingirem o peso entre 350 e $450 \mathrm{~g}$, quando foram mortos em câmara de $\mathrm{CO} 2$ e depois envolvidos individualmente em gaze e algodão e colocados em urnas de madeira e depois sepultados dentro de uma caixa de cimento enterrada no solo. As análises realizadas para verificar a variação dos fatores ambientais e dos fatores corporais não interferiram no processo de esqueletização. Após as exumações, apenas o grupo MCoT apresentou esqueletização completa com o esqueleto visível livre de quaisquer restos remanescentes. Os grupos MCST e MCCT apresentaram esqueletização mínima com massa cadavérica recobrindo todo o corpo e alguns ainda apresentando órgãos e vísceras conservados. Todos os grupos das fêmeas apresentaram esqueletização parcial. Toda massa cadavérica analisada confirmou ser adipocera. Considerando-se que os dois grupos de animais foram sepultados no mesmo local, sob as mesmas condições ambientais e corporais, simultaneamente durante o mesmo intervalo de tempo, foi possível apontar a variável hormônio como o fator responsável pela diferença observada na decomposição corpórea. 


\section{SAÚDE DA CRIANÇA E DO ADOLESCENTE}

\section{VIGILÂNCIA EPIDEMIOLÓGICA DA INFECÇÃO HOSPITALAR NAS UNIDADES DE TERAPIA INTENSIVA PEDIÁTRICA DO HOSPITAL DAS CLÍNICAS DA FA- CULDADE DE MEDICINA DE RIBEIRÃO PRETO - USP}

\section{Alessandra Kimie Matsuno}

Orientadora: Profa.Dra. Marisa Márcia Mussi Pinhata Dissertação de Mestrado apresentada em 13/04/2006

Objetivo: Descrever o perfil epidemiológico de infecção nosocomial em crianças assistidas nas Unidades de Terapia Intensiva Pediátrica (UTIP) da Unidade de Emergência (UE) e Campus (CA) do Hospital das Clínicas da Faculdade de Medicina de Ribeirão Preto da Universidade de São Paulo (HCFMRP-USP).

Métodos: Estudo observacional, prospectivo, de todas as crianças admitidas nas UTIPs durante o período de 01 de março de 2004 a 28 de fevereiro de 2005 e cujas internações duraram $\geq 24$ horas. Utilizando-se a metodologia "National Nosocomial Infection Surveillance System" (NNISS) registraram-se o número de pacientes-dia, caracteres-dia, ventiladores-dia e sondas vesicais-dia, as características dos pacientes em cada unidade, a frequiência e os sítios das infecções, o perfil microbiológico dos agentes causadores, a evolução dos pacientes e ocorrência de óbitos, calculando-se os indicadores de ocorrência de infecção. Realizou-se análise univariada e multivariada para identificação dos correlatos de infecção nosocomial.

Resultados: Observaram-se 401 crianças, 163 $(40,6 \%)$ na UE e $238(59,4 \%)$ no CA. Considerandose as características dos pacientes assistidos, classificou-se a UTIP-UE em geral e a UTIP-CA em cirúrgica. Um ou mais episódios de infecção nosocomial incidiram em 23/163 (14\%) na UE e em 57/238 (23,9\%) no CA. Taxas de incidência acumulada e de densidade de incidência de infecção foram, respectivamente, $12,7 \%$ e $23,1 \% ; 16,28$ por 1000 pacientes-dia e 47,01 por 1000 pacientes-dia. Em ambas as unidades observaram-se índices de ventilação mecânica de 0,60 respiradores-dia por pacientes-dia e altas taxas de pneumonia associada à ventilação mecânica (10,8 por 1000 ventiladores-dia na UTIP-UE e 42,6 na UTIP-CA). Índices de utilização de cateter vascular central foram de 0,28 e de 0,65 por pacientes-dia, e ocorreram 5,91 e 7,21 infecções de corrente sangüínea por 1000 cateteres-dia respectivamente na UTIPUE UTIP-CA. Detectaram-se índices de utilização de sondas vesicais (SV) por pacientes-dia de 0,15 na UTIP-UE e 0,29 na UTIP-CA, ocorrendo 5,06 infecções do trato urinário por SVD-dia nesta última unidade e nenhuma na primeira. Com relação aos sítios envolvidos, pneumonia foi o diagnóstico mais freqüente, identificado em $62,8 \%$ dos episódios de infecções na UTIP-UE e em 66,6\% na UTIP-CA. Destaca-se a alta incidência de infecção de ferida operatória na unidade do Campus (18,5\% dos episódios de infecções). Os agentes etiológicos mais freqüentemente identificados nas unidades foram Staphylococcus coagulase-negativo e Staphylococcus aureus. A internação > 4 dias associou-se, independentemente, à ocorrência de infecção em ambas as unidades (OR ajustado: 9,36 (UE); 17,33 (CA). Adicionalmente, nas crianças da UTIP-UE o uso de transfusões múltiplas e traqueostomia também foram identificados como fatores de riscos para infecções. Enquanto que nas crianças da UTIP-CA a alimentação parenteral, as cirurgias cardíacas e o índice prognóstico PRISM > 10 associaram-se a infecções. As taxas de mortalidade em ambas foram de $11 \%$, sendo que a ocorrência de óbito foi aproximadamente 3 vezes maior entre as crianças diagnosticadas com infecção hospitalar do que entre aquelas não acometidas.

Conclusão: Este estudo evidencia alarmantes taxas de infecção hospitalar na unidade de terapia intensiva pediátrica do Campus, destacando-se a elevada freqüência de pneumonia e o predomínio dos Staphylococcus como causa de infecção. A infecção aumenta a morbi-mortalidade dos pacientes ali assistidos. Portanto, medidas urgentes de controle e prevenção de infecção devem ser planejadas e implementadas. 


\section{AVALIAÇÃO DO PROGNÓSTICO NEUROPSICOLÓGICO DE CRIANÇAS APÓS TRAUMA CRANIOENCEFÁlICO E SUA ASSOCIAÇÃO COM A GRAVIDA- DE DO TRAUMA E OS ACHADOS TARDIOS DE RESSONÂNCIA MAGNÉTICA DO ENCÉFALO}

\section{Luciano Lemos Mega}

Orientadora: Ana Paula de Carvalho Panzeri Carlotti Dissertação de Mestrado apresentada em 19/04/2006

O Traumatismo Cranioencefálico (TCE) constitui a principal causa de retardo do desenvolvimento neuropsicomotor adquirido em crianças. Os objetivos do presente estudo foram avaliar o prognóstico neuropsicológico de longo prazo após TCE e sua associação com a gravidade do trauma e os achados tardios de ressonância magnética (RM) do encéfalo. Tratase de estudo de coorte de todas as vítimas de TCE, de 1 mês a 14 anos e 11 meses de idade no momento do trauma, internados no Centro de Terapia Intensiva Pediátrico (CTIP) da Unidade de Emergência do Hospital das Clínicas da Faculdade de Medicina de Ribeirão Preto - Universidade de São Paulo, no período de setembro de 1999 a agosto de 2002. Trinta e oito de 60 pacientes com TCE, admitidos no CTIP no período de estudo, foram incluídos; $66 \%$ eram do sexo masculino. Os critérios de exclusão foram morte em 8 pacientes, retardo do desenvolvimento neuropsicomotor prévio em 2, recusa em participar em 1 e endereço desconhecido em 11. A gravidade do quadro inicial após o trauma foi avaliada pela análise do prontuário e, 2 a 5 anos após o trauma, os pacientes foram submetidos a avaliação neurológica pela Glasgow Outcome Scale (GOS), Extended Glasgow Outcome Scale (GOSE) e King's Outcome Scale for Childhood Head Injury
(KOSCHI), avaliação neuropsicológica pela Escala Stanford-Binet e exame de RM do encéfalo. O prognóstico neurológico associou-se com a idade no trauma, a Escala de Coma de Glasgow (ECG) com 72 horas de internação, o Injury Severity Score (ISS) e o Pediatric Risk of Mortality na chegada ao hospital, o tempo de ventilação mecânica e o tempo de internação no CTIP. Não se associaram com o prognóstico neurológico o tempo decorrido entre o trauma e a chegada no hospital, o sexo, a pressão arterial sistólica e média, a presença de alteração pupilar, a ECG e a melhor resposta motora no momento da chegada ao hospital e as imagens de tomografia computadorizada da fase aguda. O prognóstico neurológico de longo prazo associou-se com o Quociente de Inteligência (QI) e seu componente Memória Imediata (MI). O QI correlacionou-se positivamente com a ECG 72 horas após a chegada no hospital e, negativamente, com o ISS na chegada ao hospital, o tempo de ventilação mecânica e o tempo de internação no CTIP. O componente MI correlacionou-se negativamente com o ISS na chegada ao hospital e com o tempo de internação no CTIP. Houve associação das alterações tardias de RM do encéfalo com o prognóstico, avaliado pela GOS, GOSE e KOSCHI e com o QI e a MI. São importantes o estudo da evolução neuropsicológica e a identificação precoce de crianças sob o risco de ficarem com seqüelas, para que seja instituído, precocemente, tratamento de reabilitação.

\section{ESTADO NUTRICIONAL RELATIVO AO FERRO, ALGUNS INDICADORES NU- TRICIONAIS E DESEMPENHO COGNITIVO E COMPORTAMENTAL, NA FASE PRÉ ESCOLAR, DE UMA COORTE DE CRIANÇAS NASCIDAS PREMATURA- MENTE}

\section{Gisele Maria Couto \\ Orientador: Prof. Dr. Arthur Lopes Gonçalves \\ Tese de Doutorado apresentada em 05/05/2006}

Objetivos: avaliar, na idade pré-escolar, o estado nutricional global e relativo ao ferro, o desempenho cognitivo e comportamental de 2 grupos de crian- ças nascidas pré-termo e que apresentaram ou não anemia ferropriva aos 12 meses de idade, e comparálas entre si e com grupo controle.

Casuística e Métodos: a amostra foi constituída de 56 crianças, com idade de 5 anos \pm 6 meses de idade, distribuídas em 3 grupos: "grupo 1" - 19 exprematuros que apresentaram anemia ferropriva no primeiro ano de vida; "grupo 2" - 18 ex-prematuros 
sem anemia nesta idade e "grupo 3" (controle) - 19 nascidos a termo, saudáveis e sem anemia ferropriva pregressa ou atual. Foi avaliado o estado nutricional global, por índices antropométricos (peso e estatura para a idade; e relação peso/estatura); e índices bioquímicos (proteínas totais, albumina e colesterol); o relativo ao ferro (ferro sérico, TIBC, ferritina, hemoglobina e saturação do TIBC); desempenho cognitivo e comportamental, por testes psicométricos padronizados e apropriados para a idade: Escala de Inteligência Não Verbal de RAVEN, Desenho da Figura Humana, Avaliação Cognitiva Assistida (CATM) e Escala de Comportamento Infantil A2 de RUTTER. Foram também avaliados fatores de risco social, como o estrato socioeconômico, a escolaridade materna e o tempo de freqüência das crianças a escolas.

Resultados, Discussão e Conclusões: peso, estatura e relação peso/estatura nos 3 grupos não apresentaram diferenças estatisticamente significantes $(\mathrm{p}>0,05)$ e seus valores individuais se situaram predominantemente entre os percentis 10 e 50 das curvas do $\mathrm{CDC}$, indicando bom estado nutricional, confirmado pelos índices bioquímicos, pois a proteinemia total, a albuminemia e os níveis de colesterol se situaram dentro dos limites da normalidade para pré-escolares bem nutridos e sem diferenças estatisticamente significantes entre os 3 grupos ( $p>0,05)$. O estado nutricional relativo ao ferro dos 3 grupos foi normal, pois seus indicadores principais (saturação do TIBC, ferritina e hemoglobina) estavam acima do limite infe- rior da normalidade e não houve diferenças estatisticamente significantes entre os grupos $(\mathrm{p}>0,05)$. A estratificação socioeconômica demonstrou diferença altamente significante entre os dois grupos de ex-prematuros e o Grupo Controle, pois 54\% dos ex-prematuros eram das classes sociais mais baixas (D e E) e 0\% no Grupo Controle. A escolaridade materna e das crianças foram significativamente maiores no Grupo Controle em comparação com os ex-prematuros, cujos grupos se equivaleram. As avaliações psicológicas revelaram que, embora não tivessem sido observadas diferenças estatisticamente significante entre os grupos, na Escala de Inteligência Não Verbal de RAVEN, os ex-prematuros da coorte com anemia ferropriva aos 12 meses de idade apresentaram-se funcionalmente piores, com $37 \%$ dos seus componentes com desempenho intelectual abaixo da média; o Teste de Modificabilidade do Raciocínio Analógico para Crianças (CATM), foi nitidamente prejudicado nos 2 grupos de ex-prematuros, pois 54\% deles não sabiam "cor e forma de objetos" e não conseguiram realizar o teste, o que foi mais acentuado nas crianças do grupo 1 (ex-prematuros com anemia ferropriva aos 12 meses). No desempenho comportamental, avaliado pela escala A2 de RUTTER, não demonstraram diferenças estatisticamente significantes entre os grupos, embora houvesse nítido predomínio de indivíduos com escore $>16$, que indica maior necessidade de atendimento clínico psicológico ou psiquiátrico, nos prematuros com carência de ferro aos 12 meses de idade.

\section{AVALIAÇÃO DA RESPOSTA SOROLÓGICA À VACINA CONTRA INFLUENZA NO ANO DE 2002 EM CRIANÇAS COM SIDA}

\section{Carla de Oliveira Cardoso}

Orientadora: Profa. Dra. Maria Célia Cervi

Dissertação de Mestrado apresentada em 19/05/2006

A influenza é uma doença respiratória aguda com significativa morbi-mortalidade e altamente contagiosa. São comuns complicações como otite média, pneumonia, sinusite, síndrome de Reye, entre outras. A taxa de complicações é 10 vezes maior nas crianças infectadas pelo vírus do HIV. Com o objetivo de minimizar essas complicações a OMS recomenda a vacinação contra influenza neste grupo. O objetivo do estudo foi avaliar a soroconversão à vacina contra influenza / 2002 em 101 crianças HIV+, pelo teste da inibição da hemaglutinação, avaliando se fatores como institucionalização, uso de imunoglobulina humana endovenosa (IGEV), classificação de SIDA, imunodepressão, queda de CD4 e aumento de carga viral, número de vacinações anteriores e imunidade prévia aos antígenos da vacina puderam influenciar essa soroconversão. Houve soroconversão de 61 $(60,3 \%)$ crianças. Associação negativa entre uso de IGEV e soroconversão foi observada. A vacinação por anos consecutivos não conferiu maior proteção às crianças.

Conclusão: A vacina contra influenza mostrouse eficaz em crianças HIV+ porém com taxas menores que a descrita população saudável. 


\section{ESTUDO DO EIXO GH-IGFs E IGFBPS EM $\beta$ TALASSÊMICOS POLITRANSFUN- DIDOS COM SOBRECARGA DE FERRO}

\section{Renata de Melo Pithon}

Orientador: Prof. Dr. Carlos Eduardo Martinelli Junior

Dissertação de Mestrado apresentada em 22/05/2006

Os distúrbios do crescimento são freqüentes em $ß$ talassêmicos politransfundidos. Concentrações baixas de IGF-I têm sido observadas nestes pacientes, e insensibilidade parcial ao $\mathrm{GH}$ ou deficiência de $\mathrm{GH}$ devido a depósito glandular de ferro, têm sido postulados como possibilidades. Entretanto, não está claro como a terapia quelante de ferro (TQF) pode interferir neste processo e na regulação do eixo GH-IGFIGFBPs destes pacientes. Os objetivos deste trabalho foram avaliar as concentrações de IGF-I e IGFBPs em um grupo de talassêmicos em TQF e após suspensão temporária da mesma 7 dias, as possíveis correlações entre as concentrações de IGF-I e IGFBPs e o nível sérico de ferritina, e com a dose e a duração da TQF. Foram incluídos neste estudo 12 pacientes $\beta$ talassêmicos ( 6 do sexo masculino) com idade média de 16,4 $\pm 8,3$ anos, início da TQF (desferrioxamina) com 2,4 $\pm 4,9$ anos de idade e acúmulo de ferro corporal secundário à politransfusão. Foram realizadas coletas de sangue durante uso da TQF e 7 dias após sua suspensão para dosagem de IGF-I e das IGFBPs. O IGF-I foi dosado por ensaio imunorradiométrico enquanto que as IGFBPs foram analisadas pelo mé- todo de Western Ligand Blotting. Sete dos pacientes estudados apresentavam estatura < - 1 EDP, sendo < 2 EDP em 3 deles. Quatro pacientes apresentavam hipogonadismo hipogonadotrófico e faziam reposição de esteróides sexuais, sendo que dois destes apresentavam também deficiência de $\mathrm{GH}$ e recebiam terapia substitutiva. As concentrações de IGF-I, baixas durante o uso de desferrioxamina, elevaram-se significativamente $(\mathrm{p}<0,05)$ após sua suspensão. Em 83\% (10 pacientes) dos pacientes, as concentrações de IGF-I permaneceram abaixo da média esperada para a idade, mesmo após a suspensão temporária da TQF. Não foi observada alteração nas concentrações das IGFBPs com a suspensão da desferrioxamina. Entretanto, foi encontrada correlação estatisticamente significante entre a dose de uso da desferrioxamina e as concentrações da IGFBP-3 ( $r=0,84, p=0,0061)$. Os resultados sugerem que a TQF em pacientes talassêmicos em esquema de politransfusão pode ter um importante papel na regulação do eixo GH-IGF-IGFBPs, atuando de forma distinta na regulação do IGF-I e IGFBP-3, influenciando portanto o crescimento destes pacientes. Vale ressaltar o cuidado que devemos ter na avaliação deste eixo nestes pacientes em vigência do uso contínuo de desferrioxamina. Este estudo contribui para melhor conhecimento da ação biológica da droga.

\section{SAÚDE MENTAL}

\section{HABILIDADES E CONHECIMENTOS NECESSÁRIOS À PRÁTICA PSIQUIÁTRI- CA BRASILEIRA E COMPARAÇÃO COM RESULTADOS INTERNACIONAIS}

\section{Ibiracy de Barros Camargo}

Orientador: Prof. Dr. José Onildo Betioli Contel

Tese de Doutorado apresentada em: 13/04/2006

Introdução: Nos últimos 20 anos, a psiquiatria tem sido considerada uma especialidade médica em transição acelerada. Esse contexto de mudanças é mediado por fatores sócio-econômicos, tratamento controlado, desospitalização com reorganização do atendimento e avanços científicos nas neurociências.
A abrangência das mudanças em curso tem o poder de criar grandes incertezas sobre as opções a serem tomadas pelo psiquiatra e programas de ensino.

Objetivos: Comparar resultados sobre habilidades e conhecimentos necessários à prática profissional entre psiquiatras americanos e brasileiros entre 1980, 1987 e 2000.

Método: Questionários padronizados traduzidos e adaptados foram aplicados em psiquiatras brasileiros em 2000 e os resultados foram comparados 
com estudos americanos de 1980 e 1987. As respostas foram transformadas em porcentagens e classificadas em ordem decrescente de magnitude. Essa classificação pautada pelos resultados de 1987 proporcionou comparações qualitativas e quantitativas. A aplicação do teste do quiquadrado permitiu uma análise inferencial dos resultados.

Resultados: Os resultados mostraram dois núcleos de invariância, um de 27 habilidades e 45 conhecimentos, na comparação entre resultados americanos de 1987 e brasileiros de 2000 e, um segundo núcleo de invariância, de 16 habilidades e nove conhecimentos na comparação entre resultados americanos de 1980 e 1987 e brasileiros de 2000 . No período estudado as habilidades e conhecimentos psicossociais se mostraram menos valorizadas que conhecimentos e habilidades próprios da prática médica e de psicofarmacoterapia.

Discussão: É notável como psiquiatras americanos e brasileiros tem comportamento parecido quando solicitados a responder a instrumentos padronizados sobre habilidades e conhecimentos necessários à prática psiquiátrica nos dois países. Essa parece ser uma tendência atual, mesmo entre países de desenvolvimento socioeconômico e cultural diferentes. A crescente unidade sobre as habilidades e conhecimentos necessários à prática psiquiátrica é mais uma evidência da globalização da prática psiquiátrica. Essa globalização é mais notória em conhecimentos onde o núcleo de invariância entre americanos e brasileiros chega a 45 itens de um total de 51.

Conclusões: 1. Psiquiatras americanos e brasileiros são muito semelhantes em suas respostas a questionários sobre habilidades e conhecimentos necessários à prática psiquiátrica nos dois países. $2 \mathrm{Na}$ comparação entre 1987 e 2000 essa semelhança é mais evidente em conhecimentos na proporção de 45/51 $(88,2 \%)$ e menos para habilidades na proporção de $27 / 48(56,2 \%)$. 3. Tanto psiquiatras americanos como brasileiros tendem a valorizar mais em suas respostas itens próprios da prática médica e de Psiquiatria Biológica, com ênfase em Psicofarmacoterapia e menos em Psicoterapia e Psiquiatria Social.

\section{AVALIAÇÃO DA EFICÁCIA DA INTERVENÇÃO BREVE PARA REDUÇÃO DE DANOS EM ESTUDANTES UNIVERSITÁRIOS DA UNESP QUE FAZEM USO EXCESSIVO DE BEBIDAS ALCOÓLICAS}

\section{Maria Odete Simão}

Orientadora: Prof.Dra.Florence Kerrr-Corrêa

Tese de Doutorado apresentada em 20/04/2006

Em 1998 um levantamento com 11.382 estudantes da Universidade Estadual Paulista (UNESP) mostrou que $38 \%$ já haviam experimentado alguma droga na vida, excluindo álcool e tabaco, e que $20 \%$ já haviam experimentado drogas antes de entrarem para a faculdade. Bebidas alcoólicas haviam sido consumidas por $74 \%$ dos alunos no mês anterior à entrevista $\mathrm{e}$ $30 \%$ relataram beber mais de uma vez por semana. Diante desses resultados, decidiu-se iniciar um programa de prevenção do uso de álcool para alunos de primeiros anos (calouros) de todas as faculdades da UNESP. O objetivo deste estudo foi aplicar e avaliar nesses estudantes o método BASICS, desenvolvido nos Estados Unidos por MARLATT et al. (1998). O método utiliza entrevista motivacional e é baseado no princípio da redução de danos, já que é não é uma meta realística tentar conseguir que as pessoas não usem álcool ou drogas. Dos 3.646 calouros da UNESP que participaram do rastreamento através do AUDIT e/ou RAPI, 917 (25\%) apresentavam indicadores de uso problemático de álcool, como maior quantidade e frequiência de ingestão e maior número de consequiências negativas associadas ao uso. Destes, 419 foram incluídos num ensaio clínico para avaliação da intervenção breve BASICS. Foram utilizados vários instrumentos e questionários, incluindo o questionário de SMART et al (1982), e a Avaliação de Atitudes e Comportamentos de Risco (JOHNSTON et al, 1997, 1999). Após 12 meses, os 291 alunos que receberam a intervenção breve (IB), foram re-avaliados, tendo sido comparados com dois grupos-controle (grupo controle I, com 91 participantes, que não recebeu a intervenção breve, mas participou de campanhas preventivas comunitárias, e grupo controle II, com 37 participantes, que apenas respondeu aos instrumentos no início e final do estudo). Os resultados mostram que houve: a) redução no escore do EDA do início da pesquisa e 12 meses após ( $p<0,0001)$ nos grupos IB e CI; b) uma redução nos escores do RAPI de 12 meses dos alunos dos grupos IB e CI quando comparados os dois momentos de avaliação $(\mathrm{p}<0,05)$; $)$ redução no número de doses consumidas nos finais de semana no grupo IB ( $\mathrm{p}=0,004) ; \mathrm{d})$ que os homens se envolveram em mais acidentes que as mulheres ( $\mathrm{p}<0,001)$, com redu- 
ção da média de acidentes após 12 meses nos alunos do grupo IB e controle I ( $p=0,005)$. A melhora observada não pode, no entanto, ser atribuída ao programa de prevenção proposto e, provavelmente, decorre mais do amadurecimento dos alunos do que da intervenção. Seria necessária outra abordagem, menos cen- trada no individuo, mais no ambiente e na comunidade universitária. A implantação de políticas voltadas para a educação e controle do uso de álcool torna-se necessária para que possa haver mudança nesse panorama, que é extremamente grave, na nossa sociedade e no meio acadêmico brasileiro.

\section{SAÚDE NA COMUNIDADE}

\section{OCORRÊNCIA DE MOLÉSTIA DEGENERATIVA OSTEOARTICULAR EM PACIENTES ATENDIDOS EM CLÍNICA DE FISIOTERAPIA}

\section{Ivelise Paula Fiori Brisotti}

Orientador: Prof. Dr. Afonso Dinis Costa Passos

Dissertação de Mestrado apresentada em 20/04/2006

A presente pesquisa foi desenvolvida com o objetivo de descrever a ocorrência de moléstia degenerativa osteoarticular (MDO) em pacientes atendidos em clínica especializada de fisioterapia, caracterizando a população de estudo segundo variáveis demográficas, socioeconômicas, prática de atividades físicas, índice de massa corporal e uso anterior de fisioterapia, verificando possíveis associações com a atividade profissional, afastamento do trabalho, antecedentes familiares e freqüência de orientação médica. Foram estudados 108 pacientes encaminhados para um serviço público de fisioterapia localizado em Sertãozinho, São Paulo, com diagnóstico clínico e radiológico comprovado de MDO. O estudo identificou que a doença predomina no sexo feminino $(69,4 \%)$ e na faixa etária acima de 60 anos para ambos os sexos. A obesidade é preponderante entre as mulheres (40\% contra $24,3 \%$, respectivamente). Sessenta e dois por cento dos participantes já haviam feito fisioterapia, com índices progressivamente crescentes de indivíduos das faixas etárias mais avançadas. $\mathrm{O}$ estudo permite ainda identificar que as áreas da coluna foram as mais comumente atingidas $(64,9 \%)$, com predomínio da ati- vidade braçal $(94,5 \%)$. A maioria dos participantes referiram postura durante a atividade laborativa que favorecia o desenvolvimento da MDO, porém somente $25,9 \%$ referiram afastamento anterior do trabalho. A dor foi o principal sintoma, acometendo mais intensamente a coluna e o quadril, e os antiinflamatórios corresponderam ao medicamento mais comumente utilizado. Quarenta dos 108 participantes referiram antecedentes familiares de MDO. Tratamento cirúrgico foi indicado em 10,2\% dos participantes, predominando entre os indivíduos com acometimento de joelho e naqueles com dor leve e moderada. Ocorreu predomínio dos estratos econômicos $\mathrm{C}$ e $\mathrm{D}$, sendo que o entendimento da evolução da doença pelos participantes, independentemente do estrato econômico, foi referido por apenas $25,9 \%$ deles. As atividades laborais, embora não responsáveis pelo desenvolvimento da doença, interferiram no agravamento dos sintomas, principalmente na dor articular, sendo esta o principal fator limitante do exercício profissional. Enfatiza-se a necessidade de implantação de programas de saúde pública voltados à prevenção de MDO e atendimento multidisciplinar, integrando a fisioterapia aos serviços de atenção primária à saúde, além de priorizar o aprimoramento da relação do profissional com o paciente, de modo a fazê-lo entender sua doença e participar ativamente do processo terapêutico.

\section{O CONSELHO MUNICIPAL DE SAÚdE DE FRANCA: ESTUDO SOBRE A PAR- TICIPAÇÃO E O CONTROLE SOCIAL}

Andreia Aparecida Reis Carvalho Liporoni

Orientador: Prof.Dr Juan Stuardo Yazlle Rocha

Dissertação de Mestrado apresentada em 18/05/2006
O Conselho Municipal de Saúde é um importante instrumento de interlocução regulada e institucionalizada na formulação de diretrizes e na fiscaliza- 
ção e avaliação da política de saúde no Brasil. Este estudo analisa a atuação do Conselho Municipal de Saúde de Franca - SP. Nosso objetivo foi conhecer a dinâmica do CMS no processo de gestão, financiamento e controle da política de saúde do município e como a administração municipal reconhece o Conselho como seu interlocutor na gestão do setor saúde. A pesquisa foi realizada entre fevereiro de 2004 a julho de 2005 e utilizada a abordagem qualitativa de pesquisa em saúde. A partir da análise documental das Atas do CMS, de matérias de jornais veiculadas na cidade no mesmo período e das entrevistas com os conselheiros municipais identificamos assuntos temáticos que nortearam a discussão de nosso estudo. Assim, constatamos um grande esforço dos conselheiros em assumir seu papel no desempenho de suas funções, porém encontramos alguns limites que dificultam a efetividade do controle social. Podemos citar assim, a questão político-partidária dos membros do conselho e a manipulação por parte da administração municipal. Encontramos também potencialidades para efetivação do direito à participação nas decisões que vão desde a capacitação dos conselheiros até a criação de mecanismos para dar maior visibilidade ao Conselho e assim propiciar que este possa dar voz as demandas da população.

\section{AVALIAÇÃO DA ATUAÇÃO DOS FARMACÊUTICOS NA PRESTAÇÃO DA ASSISTÊNCIA FARMACÊUTICA EM UM HOSPITAL UNIVERSITÁRIO}

\section{Thais Rodrigues Penaforte}

Orientadora: Profa.Dra. Aldaísa Cassanho Forster

Dissertação de Mestrado apresentada em 09/06/2006

Este trabalho teve por objetivo a avaliação da atuação dos farmacêuticos que trabalham na Divisão de Farmácia do HCFMRP-USP mediante o estudo de suas práticas em benefício da Assistência Farmacêutica, bem como caracterizar a Farmácia Hospitalar (FH) e seus farmacêuticos, comparando as atividades por eles desenvolvidas com aquelas recomendadas pela literatura. Foram aplicados dois questionários aos 19 farmacêuticos participantes sendo que um deles visava traçar um perfil dos participantes e o segundo verificar quais atividades são desenvolvidas pela Divisão de Farmácia e o grau de participação destes. Um terceiro questionário destinado à caracterização da Farmácia Hospitalar foi aplicado apenas à diretora técnica. Como resultados obtivemos que apesar da Farmácia possuir uma função definida dentro da estrutura organizacional do hospital bem como em relação às atividades desenvolvidas, esta ainda possui um perfil centralizado no medicamento com poucas atividades direcionadas ao paciente.Em relação às atividades essenciais a serem oferecidas pela FH, obtivemos uma atuação satisfatória com ausência de alguns segmentos como o Serviço de Informação de Medicamentos e Seguimento Farmacoterapêutico.Os farmacêuticos em geral possuem uma boa formação profissional com relação à capacitação técnica, no entanto em relação ao ano pesquisado não houve o desenvolvimento de nenhuma produção científica. Estes se encontram insatisfeitos em diversos aspectos como o dimensionamento dos recursos humanos e estrutura física e $68 \%$ se auto-avaliam relação à atuação dentro da Assistência Farmacêutica como pouco atuantes, sendo que uma boa auto-avaliação está indiretamente relacionada ao tempo de serviço.Os resultados deste estudo permitiram um maior conhecimento sobre o desempenho tanto da FH quanto de seus profissionais farmacêuticos, além de fornecer dados que podem ser utilizados como referência para a elaboração de prioridades e estratégias para o desenvolvimento e aprimoramento da Divisão de Farmácia.

\section{ESTUDO DO CONHECIMENTO DE MÉTODOS ANTICONCEPCIONAIS ENTRE ADOLESCENTES DE UMA ÁREA DE UM PROGRAMA DE SAÚDE DA FAMÍLIA DE RIBEIRÃO PRETO-SP}

\section{Daniella Tech Doreto}

Orientadora: Profa.Dra. Elisabeth Meloni Vieira

Dissertação de Mestrado apresentada em 12/06/2006
Os cuidados com a contracepção na adolescência são fundamentais para vivenciar a sexualidade de forma plena, evitando uma gravidez não 
planejada ou não desejada, bem como a transmissão de doenças.

Em meio a uma realidade global de elevados índices de gravidez na adolescência e aumento na incidência de doenças sexualmente transmissíveis, é necessário pensar em uma opção contraceptiva que proporcione a dupla proteção.

Neste sentido, o presente estudo propôs-se a analisar o conhecimento das adolescentes, cadastradas em um Núcleo do Programa de Saúde da Família de Ribeirão Preto-SP, em relação aos métodos anticoncepcionais, especialmente aqueles voltados para a prevenção de gravidez e doenças sexualmente ao mesmo tempo.

A amostra foi composta por 90 adolescentes, do sexo feminino, na faixa etária compreendida entre 15 e 19 anos de idade. Os dados foram coletados através de entrevistadas domiciliares, com apoio de um questionário estruturado.

Os resultados da pesquisa demonstraram que as adolescentes eram predominantemente brancas, solteiras, estudavam e pertenciam à categoria sócio-eco- nômica $\mathrm{C}$ e D. A maioria das entrevistadas conhecia métodos de dupla proteção $(54,4 \%)$ sendo o preservativo masculino o mais citado $(91,8 \%)$. Quanto ao uso de métodos de dupla proteção em algum momento da vida, $58,9 \%$ das adolescentes referiram ter feito uso, o que indica que $98,5 \%$ das que iniciaram a vida sexual, já se protegeram de gravidez e doenças simultaneamente alguma vez na vida.

Quanto às atitudes em relação ao uso dos métodos, a maioria teve atitude liberal $(43,3 \%)$, seguida de $28,9 \%$ que tiveram atitude neutra e $27,7 \%$ atitude conservadora, o que evidenciou que as atitudes não se configuram como obstáculos para o uso dos métodos.

$\mathrm{O}$ estudo indicou que o conhecimento sobre os métodos anticoncepcionais não garante o seu uso e as atitudes não são barreiras que impedem práticas efetivas de proteção. Assim, questões de gênero e os diversos contextos devem ser considerados para um melhor entendimento das questões que envolvem a saúde sexual e reprodutiva dos adolescentes, bem como para a concepção de ações efetivas no âmbito das políticas públicas.

\section{A INFLUÊNCIA DO ESTILO DE VIDA NA REINTERNAÇÃO HOSPITALAR DE PACIENTES DIABÉTICOS}

\section{Grasielle Silveira Tavares}

Orientador: Prof. Dr. Juan Stuardo Yazlle Rocha

Dissertação de Mestrado apresentada em 12/06/2006

O Diabetes Mellitus tipo 2, apresenta-se atualmente como um sério problema de saúde pública, devido as suas causas, complicações e grande incidência na população, afetando vários aspectos da vida das pessoas, provocando rupturas com modo de vida anterior e necessitando de modificações nos hábitos diários, sendo responsável por vários graus de incapacidade, o que leva a uma modificação no estilo de vida e conseqüentemente elevação dos custos com o tratamento, pois as reinternações tornam-se freqüentes, trazendo ônus para o Sistema de Saúde, para o paciente e sua família. Esta pesquisa objetiva investigar a influência do estilo de vida na reinternação hospitalar de mulheres com diabetes tipo 2. A população estudada foi composta por 50 mulheres, com faixa etária entre 45 e 65 anos, as quais foram divididas em dois grupos: Grupo Teste (composto por mulheres com duas ou mais hospitalizações entre janeiro de 2002 a de- zembro de 2004) e Grupo Controle (composto por mulheres com apenas uma internação no período de estudo citado acima). Para a escolha da amostra levou-se em consideração o critério de inclusão, o qual estabelece que as mulheres dos dois grupos são assistidas pelo Ambulatório de Endocrinologia do Hospital das Clínicas da Faculdade de Medicina de Ribeirão Preto. A coleta de dados foi realizada no período de 22 de agosto a 19 de setembro de 2005 , através da aplicação do questionário elaborado pela pesquisadora e utilização parcial da Medida Canadense de Desempenho Ocupacional - MCDO. Os instrumentos utilizados mostraram-se capazes de atender os objetivos do presente trabalho. Os resultados obtidos indicam que embora algumas mulheres do grupo controle apresentem dificuldades na realização e participação nas atividades cotidianas, no trabalho, na realização de dieta e atividade física, problemas nas relações sociais, tarefas domésticas, passeios/viagens, a grande maioria continua desempenhando suas tarefas, mostrando a importância que as atividades cotidianas têm em sua vida, sendo capazes de apresentar um estilo de vida 
mais saudável. Porém, as mulheres do grupo teste mostraram que as dificuldades citadas estão fortemente acentuadas e muitas convivem com a total ausência de atividades e vida social, mostrando-se insatisfeitas com a vida que levam, a qual não apresenta desafios, interesses e vontades. A forma de lidar com a doença, sua adaptação em relação a ela, as limitações físicas e emocionais trazidas pelas complicações são fatores relevantes que evidenciam a possibilidade de haver uma correlação entre as reinternações hospitalares das mulheres do grupo teste e o estilo de vida por elas adotado. Considerando-se que as atividades (trabalho, lazer, autocuidado, sociais, culturais e familiares) preenchem as necessidades humanas básicas, é extremamente importantes estudos que compreendam estes aspectos referentes ao estilo de vida, para ampliar os conhecimentos em relação ao diabetes e propor estratégias eficazes de intervenção. O Terapeuta Ocupacional junto à equipe multidisciplinar pode contribuir para o resgate das capacidades e habilidades perdidas através da realização de atividades que possibilitem uma postura mais ativa frente à vida.

\section{SAÚDE BUCAL EM IDOSOS: QUEIXAS RELATADAS, RIBEIRÃO PRETO (SP)}

\section{Alexandre Fávero Bulgarelli}

Orientadora: Profa. Dra. Amábile R. Xavier Manco

Dissertação de Mestrado apresentada em 27/06/2006

O trabalho estudou queixas, cuidados, importância e satisfação com a saúde bucal em uma população de idosos cadastrados no Núcleo de Saúde da Família III na cidade de Ribeirão Preto. Os idosos foram selecionados para participarem na pesquisa levando-se em conta a capacidade cognitiva (Mini Mental Examination), as atividades normais da vida cotidiana, bem como o consentimento em participar por livre vontade. Os participantes responderam um questionário, em suas residências, sobre saúde bucal elaborado especificamente para o presente estudo, em data previamente agendada pelo pesquisador. O questionário continha questões relacionadas à situação sócio-demográfica, cuidados com saúde bucal, situação protética, auto-avaliação sobre saúde bucal, bem como queixas referentes a este fato. Procurou-se desta forma, identificar o perfil da população estudada segundo levantamento das queixas mais prevalentes, situação em relação aos cuidados com dentes e/ou próteses, bem como a satisfação e o valor dado à saúde bucal. Os dados receberam tratamento estatístico para observação de associações de variáveis através de Teste exato de Fisher e Qui-quadrado, aceitando-se a associação quando o valor de $p$ era menor ou igual a 0,05. A população adscrita, no referido núcleo no período de realização do presente estudo, era de 503 idosos dos quais foram entrevistados 261 , e deste número, 90 idosos $(34,5 \%)$ eram do sexo masculino e 171 $(65,5 \%)$ do sexo feminino. A população possuía baixa escolaridade (60,2\% com até 4 anos de estudo) e maior número de representantes com idade entre 60 a 69 anos $(46,7 \%)$. A maioria dos idosos morava com familiares e os homens eram os responsáveis financeiros. Parte significativa dos entrevistados relatou ser desdentada total $(48,7 \%)$ e este fato esteve associado à idade, escolaridade e convívio na mesma residência. Os indivíduos desdentados totais referiram sua saúde bucal como importante $(45,2 \%)$ e boa $(77,7 \%)$ sendo que, entre indivíduos satisfeitos com sua saúde bucal 53,6\% eram desdentados totais, e tais variáveis estiveram associadas. Em relação aos cuidados, idosos mais jovens relataram maior número de escovações diárias dos dentes e/ou próteses. Quanto às queixas observou-se maior ocorrência de lesões/feridas na cavidade bucal, queixas referentes à articulação temporomandibular (ATM), mau hálito, boca seca e dificuldade para mastigar. Dentre estas queixas o mau hálito $(\mathrm{p}=0,015)$ e a dificuldade para mastigar $(\mathrm{p}=0,000)$ mostraram-se estatisticamente associadas à quantidade de dentes. A queixa referente à dificuldade para mastigar estava associada à mobilidade de próteses inferiores $(\mathrm{p}=0,001)$. Desta forma concluiu-se que os cuidados com a saúde bucal diminuíram com o avançar da idade, os idosos relataram sentir-se satisfeitos com suas condições de saúde bucal, classificando a mesma como importante, e ser desdentado total não significou necessariamente atribuir valores negativos a esta condição. A falta de dentes não foi referida como uma queixa porém apareceu associada à insatisfação com a saúde bucal. E finalmente concluiu-se que a dificuldade para mastigar esteve associada à idade e à mobilidade das próteses inferiores, sendo que na faixa etária mais avançada esta queixa foi mais freqüente. 


\section{AGENTE COMUNITÁRIO DE SAÚdE NA VISÃO DA EQUIPE MULTIPROFIS- SIONAL}

\section{Daniela Cristina Seabra}

Orientador: Prof.Dr. Antonio Carlos D. de Carvalho

Dissertação de Mestrado apresentada em 29/06/2006

Este estudo foi realizado em cinco Unidades de Saúde da Família (USFs), denominados Núcleos de Saúde da Família (NSFs), pertencentes ao Centro de Saúde Escola da Faculdade de Medicina de Ribeirão Preto da Universidade de São Paulo (CSE-FMRPUSP). Procuramos compreender como os profissionais das equipes de saúde da família percebem o papel do agente comunitário de saúde (ACS). Trata-se de pesquisa qualitativa. Os dados foram obtidos por meio de entrevistas semi-estruturadas, realizadas com todos os médicos, enfermeiras e auxiliares de enfermagem que já trabalhavam nos NSFs por mais de dois anos. Identificamos unidades temáticas pela análise de conteúdo. Os resultados evidenciam diversos posicionamentos sobre o papel do ACS na equipe. A maioria dos profissionais vê o ACS como um ator que pode facilitar as relações entre a equipe e a comunidade, servindo de elo entre esses dois universos. Para outros, entretanto, o fato de o ACS atuar na mesma comunidade em que mora pode gerar situações que, em vez de facilitarem o trabalho da equipe, podem criar mais problemas. Os profissionais também revelaram algumas vivências nos NSFs, traduzidas como "dificuldades", que devem ser revistas para o sucesso do Programa Saúde da Família (PSF). Constatamos ainda que o ACS é um importante profissional na equipe, mas que sozinho não opera mudanças, sendo fundamental o comprometimento de todos os profissionais do PSF, para que as atividades sejam desenvolvidas, o que requer uma mudança de comportamento, que representa um desafio a ser superado.

\section{ESTUDO DAS CARACTERÍSTICAS ALIMENTARES DE CRIANÇAS E ADOLES- CENTES COM EXCESSO DE PESO E DE SEUS CUIDADORES EM UMA UNIDA- DE BÁSICA DE SAÚDE DO MUNICÍPIO DE UBERLÂNDIA, MINAS GERAIS}

\section{Camila Azenha Alves de Rezende \\ Orientador: Prof.Dr.Amaury Lelis Dal Fabbro \\ Dissertação de Mestrado apresentada em 30/06/2006}

Este estudo teve como objeto, crianças e adolescentes com excesso de peso ( 20 do sexo feminino, 41 do masculino) e seus 61 cuidadores (55 do sexo feminino, 6 do masculino), usuários do Centro de Saúde Escola de peso e seus cuidadores, usuários do Centro de Saúde Escola Jaraguá em Uberlândia-MG. Constitui-se como objetivo, investigar características alimentares destes usuários, como uma contribuição ao estudo da obesidade nesta população. $\mathrm{O}$ método adotado foi o descritivo, por meio de uma amostra de conveniência. O instrumento utilizado foi um questionário fechado composto de dez partes. O armazenamento de dados foi feito no programa "Epidate". A análise dos dados foi feita pelo programa estatístico "Epinfo 6.0" e pelo "Excel". Foram feitas correlações de Spearman, Pearson, e Contingência para verificar associação de variáveis entre os cuidadores e as crianças e adolescentes com excesso de peso. Os resultados desta investigação indicam que apesar das crianças e adolescentes e suas famílias fazerem pelo menos as refeições principais, e terem horário determinado para fazê-las, há erro alimentar (excesso de carboidratos e gorduras, alimentos com alta densidade calórica principalmente na colação, lanche e ceia). $\mathrm{O}$ sedentarismo e associações de comportamentos como hábito de assistir televisão (principalmente na hora do almoço e jantar) entre cuidadores e crianças e adolescentes, também ficou evidente, o que pode indicar influência de hábitos familiares. Existem questões a serem respondidas, como a relação entre aleitamento e excesso de peso que na literatura aparece como fator protetor e no presente estudo não parece ter sido. São necessários estudos mais aprofundados a fim de entender melhor as necessidades e problemas dessas crianças e adolescentes com excesso de peso e seus cuidadores. 